
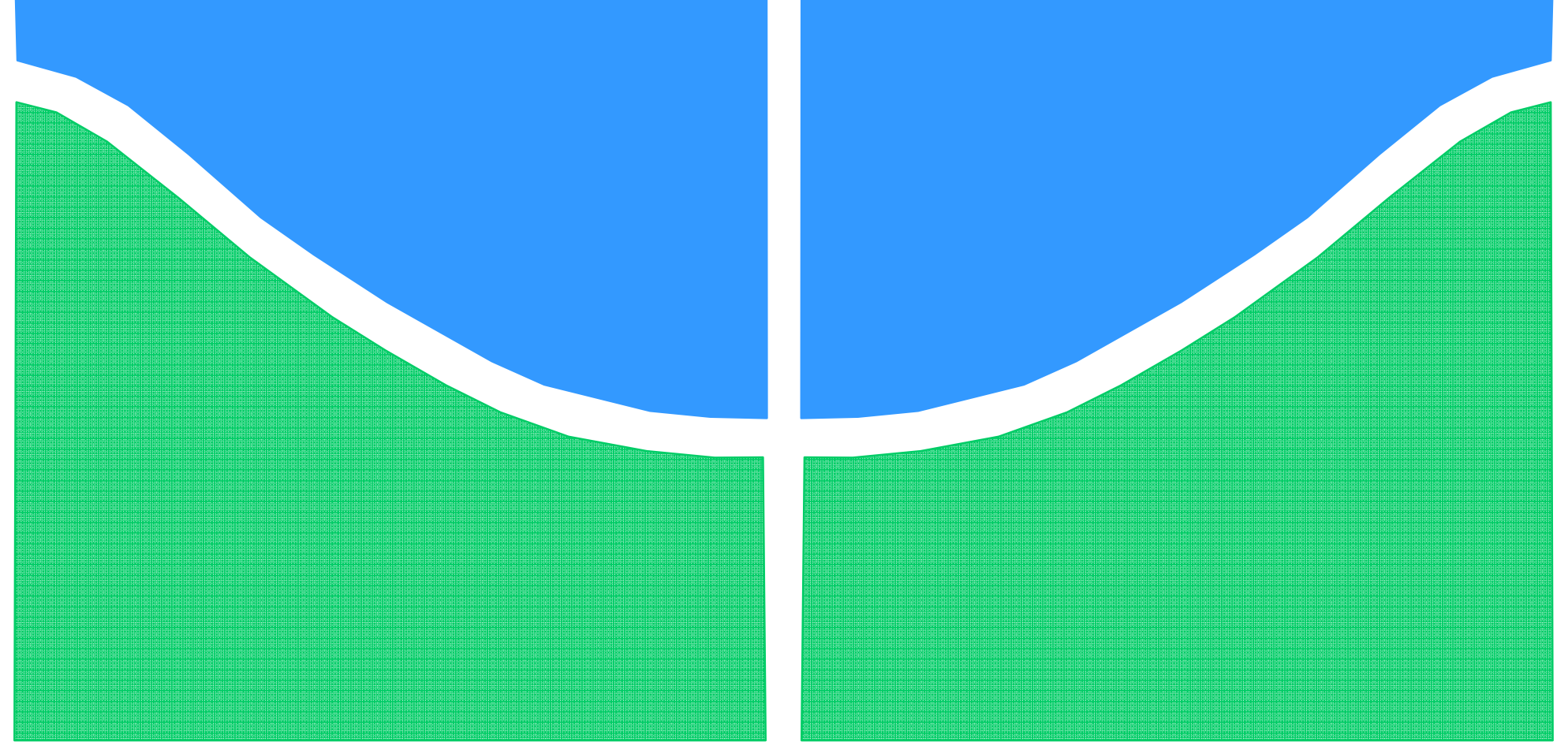

PROJETO FINAL DE GRADUAÇÃo

\title{
EQÜIPOTENCIALIZAÇÃO: SEGURANÇA E FUNCIONALIDADE NAS INSTALAÇÕES ELÉTRICAS DA FACULDADE DE TECNOLOGIA
}

MÁRCIA NELMA LOPES DAMASCENO

NATÁLIA TUTIDA IRYODA

\section{UNIVERSIDADE DE BRASÍLIA}

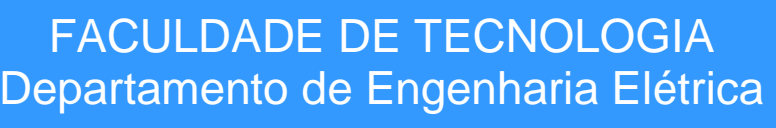


UNIVERSIDADE DE BRASÍLIA

Faculdade de Tecnologia

Departamento de Engenharia Elétrica

\title{
EQÜIPOTENCIALIZAÇÃO: SEGURANÇA E FUNCIONALIDADE NAS INSTALAÇÕES ELÉTRICAS DA FACULDADE DE TECNOLOGIA
}

\author{
MÁRCIA NELMA LOPES DAMASCENO \\ NATÁLIA TUTIDA IRYODA
}

\begin{abstract}
PROJETO DE GRADUAÇÃO SUBMETIDO AO DEPARTAMENTO DE ENGENHARIA ELÉTRICA DA FACULDADE DE TECNOLOGIA DA UNIVERSIDADE DE BRASÍLIA, COMO PARTE DOS REQUISITOS NECESSÁRIOS PARA A OBTENÇÃO DO GRAU DE ENGENHEIRO ELETRICISTA.

APROVADO POR:
\end{abstract}

ALCIDES LEANDRO DA SILVA, Mestre, UnB (ORIENTADOR)

FRANCISCO DAMASCENO FREITAS, Doutor, UnB (EXAMINADOR)

MAURO MOURA SEVERINO, Mestre, UnB (EXAMINADOR)

BRASÍLIA/DF, 19 DE DEZEMBRO DE 2006 


\section{FICHA CATALOGRÁFICA}

DAMASCENO, MARCIA NELMA LOPES \& IRYODA, NATALIA TUTIDA

Eqüipotencialização: Segurança e Funcionalidade nas Instalações Elétricas da Faculdade de Tecnologia [Distrito Federal] 2006.

(ENE/FT/UnB, Engenheiro, Engenharia Elétrica, 2006).

Projeto Final de Graduação - Universidade de Brasília, Faculdade de Tecnologia. Departamento de Engenharia Elétrica.

\section{REFERÊNCIA BIBLIOGRÁFICA}

DAMASCENO, MARCIA NELMA LOPES \& IRYODA, NATALIA TUTIDA (2006). Eqüipotencialização: Segurança e Funcionalidade nas Instalações Elétricas da Faculdade de Tecnologia. (Projeto Final de Graduação), Departamento de Engenharia Elétrica, Universidade de Brasília, Brasília, DF.

\section{CESSÃO DE DIREITOS}

NOME DO AUTOR: Márcia Nelma Lopes Damasceno \& Natália Tutida Iryoda

TÍTULO DA DISSERTAÇÃO: Eqüipotencialização: Segurança e Funcionalidade nas Instalações Elétricas da Faculdade de Tecnologia.

GRAU/ANO: Bacharel/2006.

É concedida à Universidade de Brasília permissão para reproduzir cópias deste Projeto Final de Graduação e para emprestar ou vender tais cópias somente para propósitos acadêmicos e científicos. Os autores reservam outros direitos de publicação e nenhuma parte desta dissertação de graduação pode ser reproduzida sem a autorização por escrito dos autores.

Márcia Nelma Lopes Damasceno

Natália Tutida Iryoda 


\section{AGRADECIMENTOS}

Agradecer é reconhecer o apoio das pessoas à realização daquilo que não se consegue individualmente. É compartilhar as gratificações e satisfações dos frutos de um trabalho que só foi possível graças às pessoas que colaboraram no que lhes era possível, e que vieram a nos acrescentar.

Agradecemos a Deus por esse momento tão importante nas nossas vidas acadêmica e profissional.

Aos vários amigos por oferecerem horas valiosas dos seus tempos para nos auxiliarmos no que fosse necessário, em especial, Bernardo Menezes, Lucas Guimarães e Maria Gabriela que contribuíram para que este trabalho pudesse ser desenvolvido.

Ao professor Alcides Leandro, nosso orientador, por toda a atenção e apoio que nos foram dedicados, guiando-nos intelectual e didaticamente nesta última e importante etapa da Graduação.

Aos engenheiros e técnicos do SG-11, em especial ao Silmar Alves, por se apresentar sempre disponível a nos esclarecer dúvidas e nos acompanhar nas pesquisas de campo.

Aos engenheiros e técnicos da manutenção técnica da Prefeitura, Ceplan (Centro de Planejamento Oscar Niemeyer) e Faculdade de Tecnologia, em especial, Antônio Marrocos e o engenheiro Luiz César, por terem sido prestativos e atenciosos, fornecendo informações importantes e indispensáveis.

A autora Natália Iryoda agradece aos seus pais Augusto e Helena, seus irmãos Flávio e Maurício pela confiança, ensinamentos e estímulo. Agradecimento, em especial, ao Thadeu pelo incentivo, carinho, cumplicidade e toda paciência. Aos amigos que acompanharam nesse crescimento acadêmico e ajudaram em conversas e sugestões enriquecedoras. Agradecimentos sinceros para amiga Márcia Nelma, pela relação de parceira e companheirismo que soube converter momentos de impaciência em boas risadas.

A autora Márcia Lopes agradece em especial aos seus pais José Moreira e Ediman, seus irmãos Thiago e Sarah. Dedica ainda aos amigos por terem apoiado e serem 
compreensivos nesse período de afastamento e ansiedade que corresponde ao desenvolvimento da dissertação. À sua parceira, Natália, companhia de dias consecutivos, partilhando conhecimento, medos e expectativas.

Por fim, agradecer àquelas pessoas que auxiliaram na organização das informações da pesquisa e, que direta ou indiretamente nos incentivaram na busca do conhecimento. 


\section{DEDICATÓRIA}

As autoras dedicam este trabalho aos seus

amigos e às suas respectivas

famílias. 


\section{RESUMO}

Este trabalho apresenta um estudo sobre o conceito e os princípios de eqüipotencialização, considerando-se o novo foco dado pela norma NBR 5410/2004 a este

tema. É apresentada uma revisão bibliográfica no que se refere ao conceito de choque elétrico, bem como dos níveis de proteção dentro de uma instalação. O trabalho segue no sentido de frisar a necessidade de garantia da segurança pessoal e integridade dos equipamentos. A norma 5419/2005 foi também fonte de pesquisa no que concerne à proteção contra descargas atmosféricas.

$\mathrm{Na}$ introdução, frisou-se a diferenciação entre os conceitos de aterramento e eqüipotencialização, deixando claro, entretanto, que são indissociáveis. Foram citados e descritos os elementos constituintes de um sistema de eqüipotencialização, e sua configuração geral, focando-se, para quaisquer casos em particular, a intenção final de sua implementação. Neste contexto, foi introduzida a importância da consideração do fenômeno compatibilidade eletromagnética.

O tema foi desenvolvido no contexto da situação atual das instalações da FT, buscando-se evidenciar a importância da execução de projetos e readequações fazendo-se os devidos registros.

Este projeto realiza uma integração eficiente entre diversas necessidades das instalações em particular. Primeiramente, refere-se à introdução dos princípios relacionados ao aterramento e eqüipotencialização, cujas definições e grau de importância são pouco difundidos, apesar de serem temas de conhecimento geral comum, muitas vezes de forma simplória e errônea. A este se somam os dados obtidos, que servirão para implementação do necessário projeto de readequações do sistema de eqüipotencialização do prédio da FT 


\begin{abstract}
This thesis presents a study about the concepts and principles of equipotentialization, taking into account the NBR 5410/2004 standard, which regulates this subject. A bibliographical revision is presented concerning the concept of electric shock, as well as levels of protection inside an installation. This research emphasizes the need to guarantee the security of people and the integrity of equipments. The 5419/2005 standard was also a research source regarding the protection against atmospheric discharges.

The concepts of grounding and equipotentialization were introduced, and the difference between them was emphasized, making it clear, however, that these concepts cannot be considered individually. The elements that make up a equipotentialization system were described, as well as its general configuration. In this context, the importance of taking the electromagnetic compatibility phenomenon into account was introduced.

The theme was developed regarding the current situation of the Faculty of Technology, searching to emphasize the importance of projects execution and making the essential comments.

This project carries through an efficient integration of the many needs a particular installation might have. First, it refers to the introduction of principles related to grounding and equipotentialization. Even though these subjects are known by ordinary people, many times the concepts are treated either in a simple manner or wrongly. To this were added the results obtained, that will aid the implementation of the necessary project to readequate the equipotentialization system of the Faculty of Technology building.
\end{abstract}




\section{SUMÁRIO}

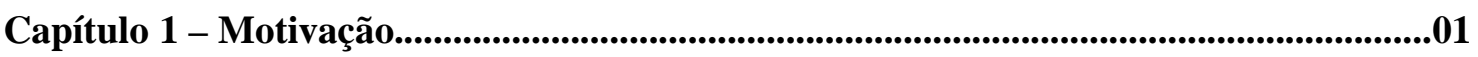

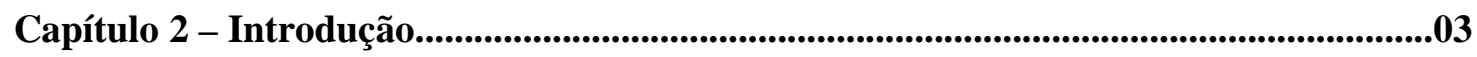

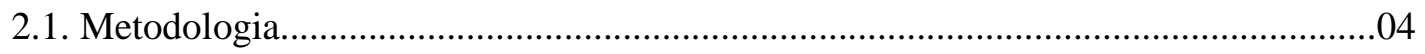

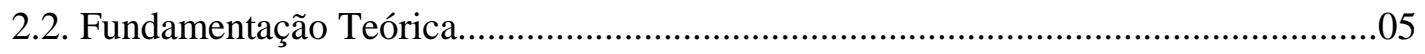

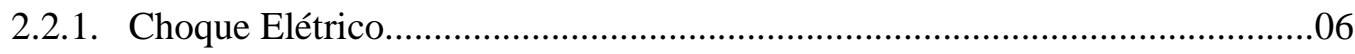

2.2.2. Níveis de proteção................................................................................. 08

2.2.3. Proteção contra Contatos Indiretos...............................................................09

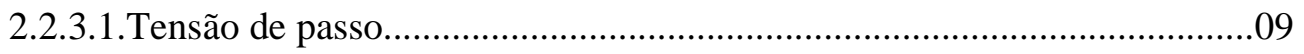

2.2.3.2.Tensão de contato ou de toque.............................................................. 10

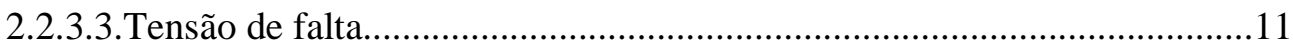

2.2.4. Aterramento para descargas atmosféricas..................................................11

2.2.4.1. Resposta em freqüência............................................................... 14

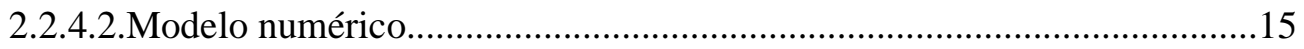

Capítulo 3 - O Aterramento e a Eqüipotencialização..........................................................17

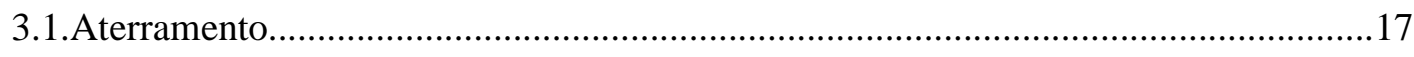

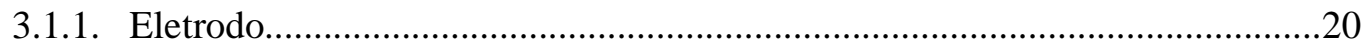

3.1.1.1. Resistência de terra de uma haste..........................................................24

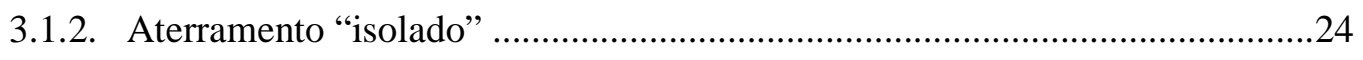

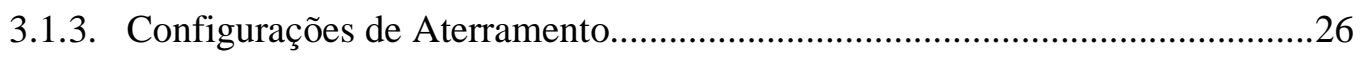

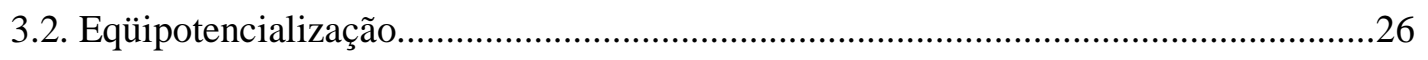

3.2.1. Eqüipotencialização principal.....................................................................29

3.2.1.1. Barramento Equipotencial Principal.....................................................30

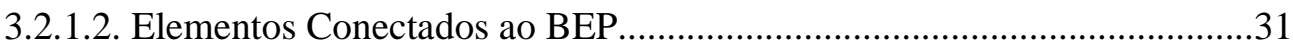


3.2.2. Eqüipotencialização Suplementar ou Eqüipotencialização Local.......................34

3.2.3. Eqüipotencialização e Compatibilidade Eletromagnética..................................34

3.4. Estruturas Físicas Metálicas da Edificação............................................................... 38

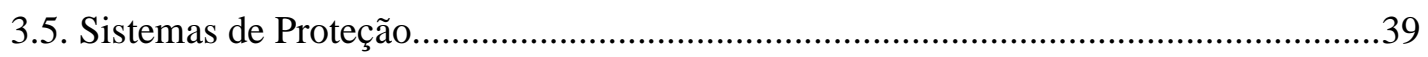

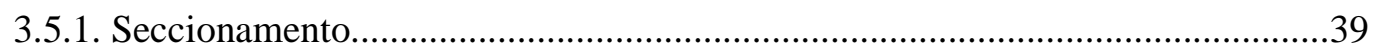

3.5.2. Dispositivo de Proteção contra Surtos Elétricos...............................................41

3.5.2.1. Seleção e Localização dos DPS..............................................................44

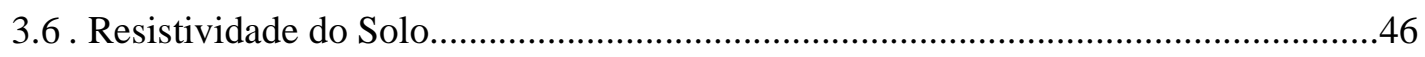

3.6.1. Características do solo do Distrito Federal....................................................47

3.6.1.1. Estratificação do solo.........................................................................49

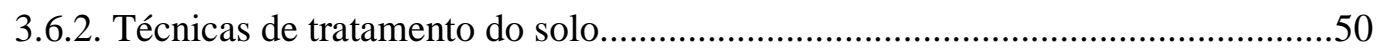

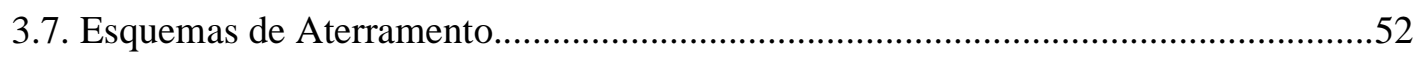

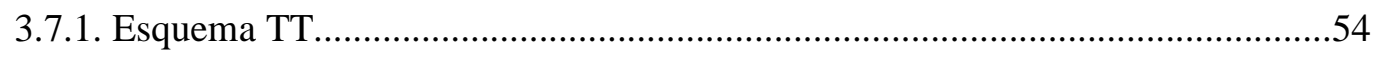

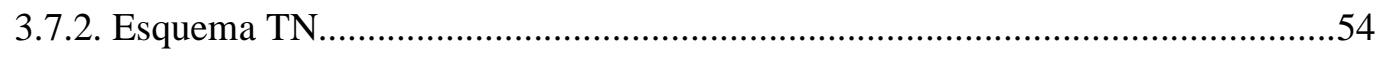

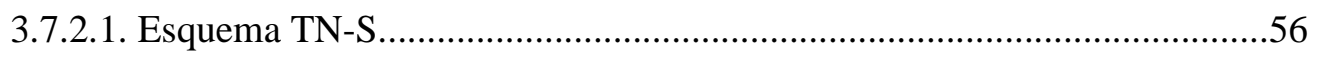

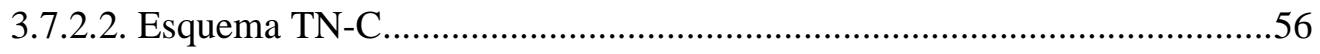

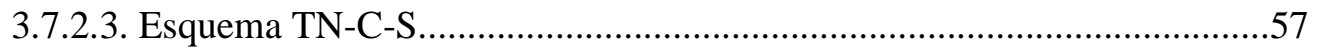

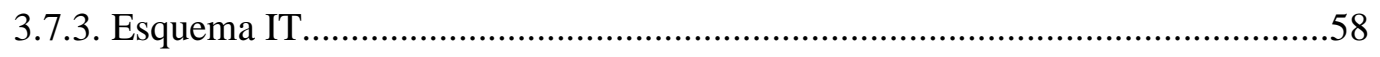

3.8. Leis e Normas Referentes à Segurança das Instalações.............................................59

Capítulo 4 - Instalações Elétricas da Faculdade de Tecnologia.......................................60

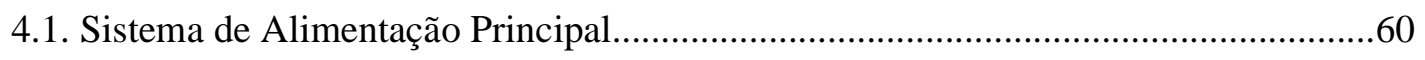

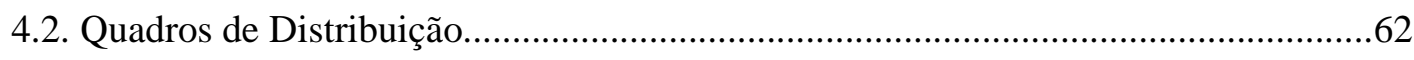

4.3. Sistema de Aterramento da Faculdade de Tecnologia.............................................70

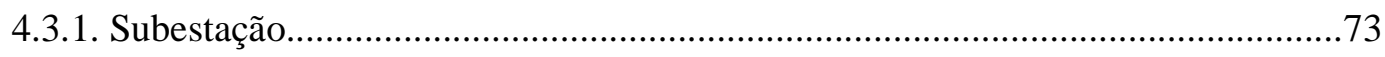

4.3.2. Departamento da Engenharia Elétrica............................................................73

4.3.3. Departamento da Engenharia Mecânica........................................................... 75

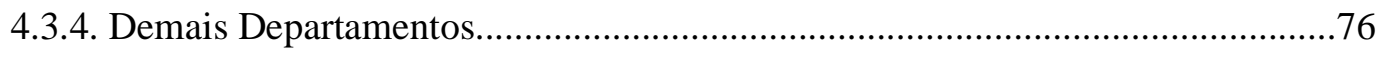


Capítulo 5 - A Equiipotencialização na Faculdade de Tecnologia.......................................77

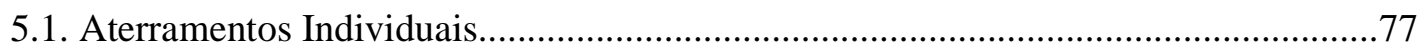

5.2. Compatibilidade Eletromagnética.................................................................. 78

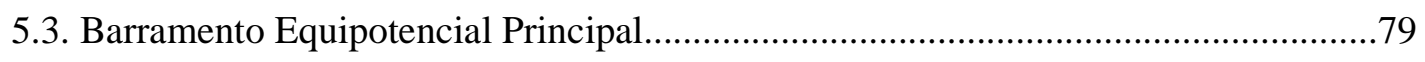

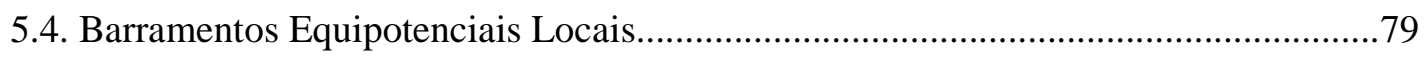

Capítulo 6 - Recomendações.........................................................................................81

Capítulo 7 - Considerações Finais.....................................................................................83

Referências Bibliográficas...........................................................................................................................85

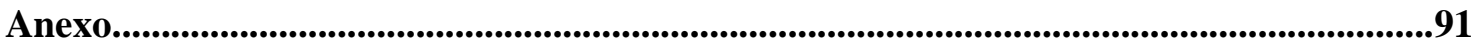




\section{LISTA DE FIGURAS}

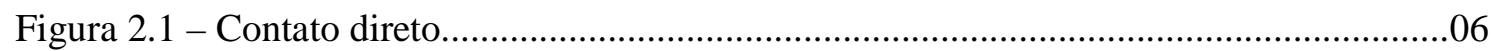

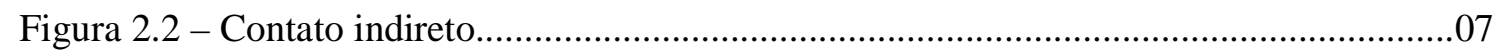

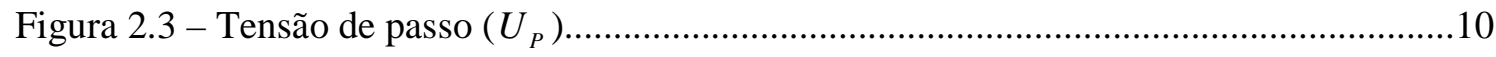

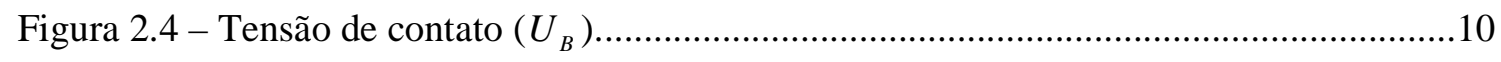

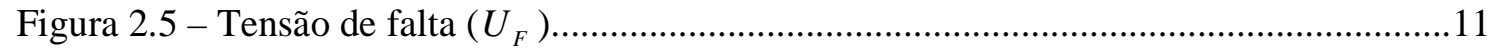

Figura 2.6 - Esquema do Modelo de Condutor de Aterramento..........................................16

Figura 3.1 - Esquema Básico e Geral de um Aterramento...................................................19

Figura 3.2 - Superfícies Equipotenciais de Uma Haste Cravada em Solo Homogêneo...........21

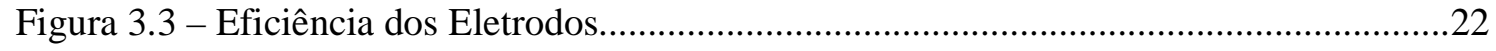

Figura 3.4 - Superfícies Equipotenciais de Duas Hastes.................................................22

Figura 3.5 - Zona de Interferência nas Linhas Equipotenciais de Duas Hastes......................23

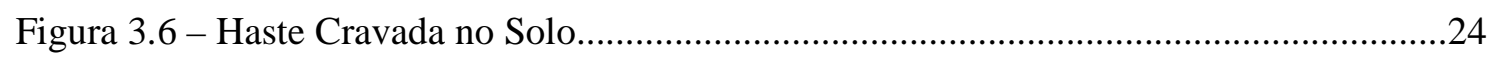

Figura 3.7 - Esquema de Representação de Aterramento com Eqüipotencialização................29

Figura 3.8 - Eqüipotencialização Principal numa Situação Hipotética...................................30

Figura 3.9 - Barramento Equipotencial Principal...............................................................32

Figura 3.10 - Esquema Referente aos Agregados Necessários ao Resultado Satisfatório dos

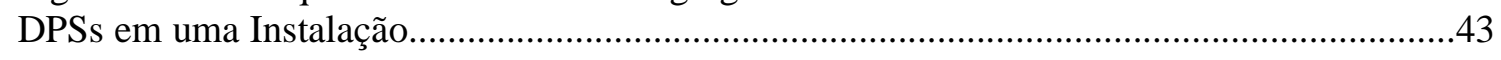

Figura 3.11 - Suportabilidade a Impulsos nas Quatro Categorias Especificadas na NBR

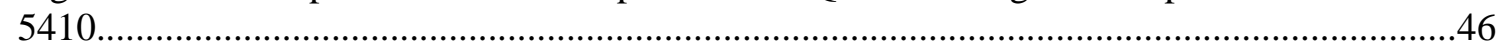

Figura 3.12 - Perfil de Solo do Campo Experimental da UnB ...........................................48

Figura 3.13 - Estratificação do Solo em Duas Camadas......................................................49

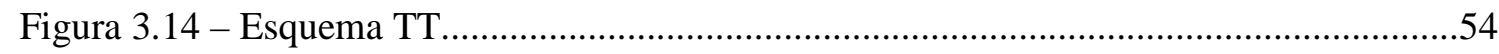

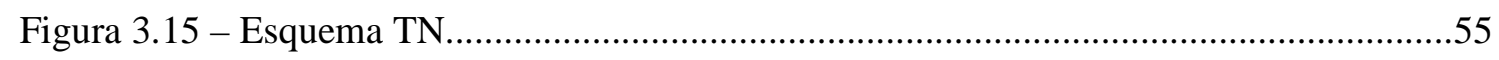

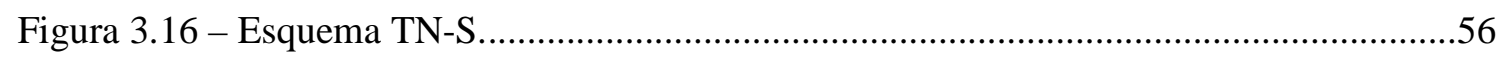

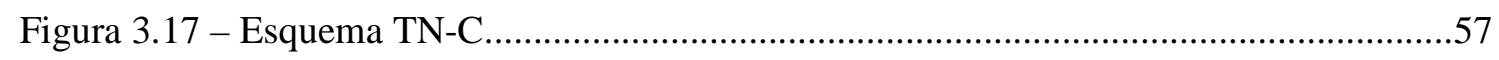




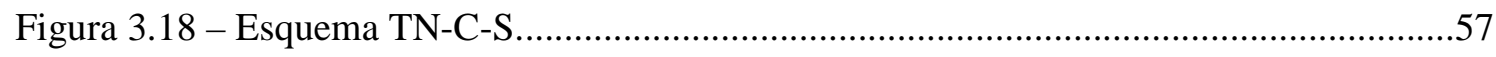

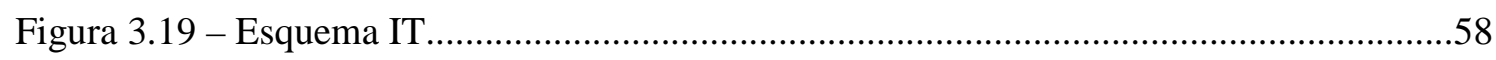

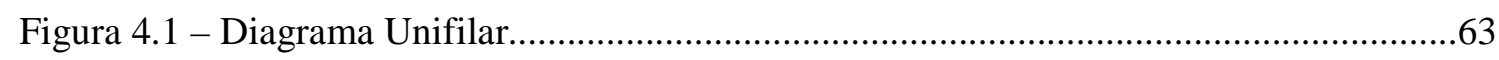




\section{LISTA DE FOTOS}

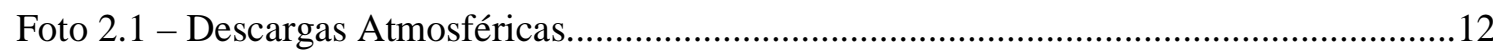

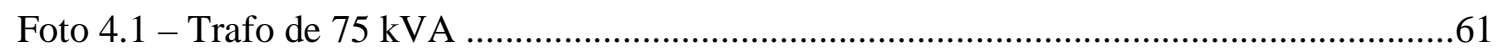

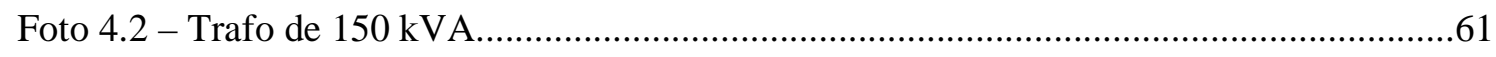

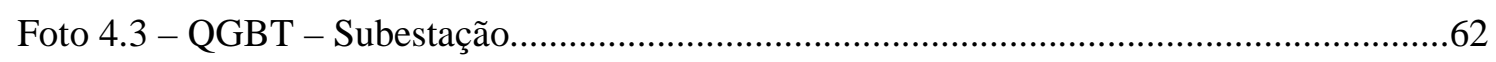

Foto 4.4 - Quadro de Distribuição da Eng. Elétrica..............................................................64

Foto 4.5 - Quadro de Distribuição da Eng. Civil..................................................................64

Foto 4.6 - Quadro de Distribuição da Eng. Mecânica............................................................65

Foto 4.7 - Quadro de Distribuição do Bloco D....................................................................65

Foto 4.8 - Quadro de Distribuição da Eng. Mecatrônica........................................................66

Foto 4.9 - Quadro de Distribuição da Eng Florestal............................................................66

Foto 4.10 - Quadro de Distribuição da Eng. Redes.............................................................67

Foto 4.11 Quadro de Distribuição do NMI........................................................................67

Foto 4.12 - Quadro de Distribuição do CDT ...............................................................68

Foto 4.13- Quadro de Distribuição do GRACO................................................................68

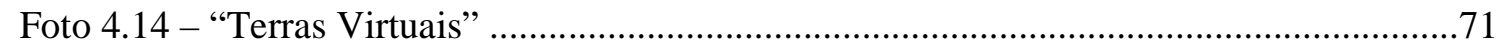

Foto 4.15 - “Terras Virtuais” Desconectados................................................................... 72

Foto 4.16 - Caixas de Inspeção da Malha de Aterramento....................................................74

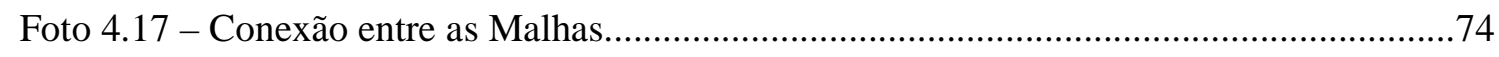

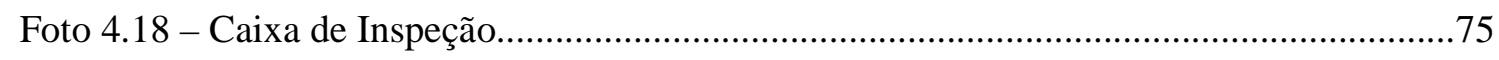

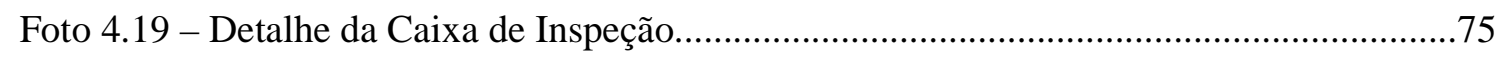




\section{LISTA DE TABELAS}

Tabela 3.1 - Comparação entre os Produtos Normalmente Utilizados para Tratamento

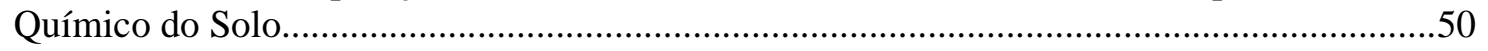

Tabela 3.2 - Valores Típicos de Resistividade de Solo.......................................................51

Tabela 4.1-Características dos Quadros de Distribuição.......................................................69

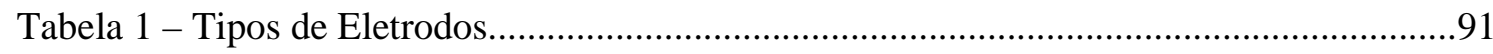




\section{LISTA DE ABREVIAÇÕES E SÍMBOLOS}

\begin{tabular}{|c|c|}
\hline Abreviação & Significado \\
\hline ABNT & Associação Brasileira de Normas Técnicas \\
\hline A & Ampère \\
\hline A & Área \\
\hline BEL & Barramento Equipotencial Local \\
\hline BEP & Barramento Equipotencial Principal \\
\hline $\mathrm{C}$ & Capacitância \\
\hline $\mathrm{cm}$ & centímetro \\
\hline CDT & Centro de Apoio ao Desenvolvimento Tecnológico \\
\hline CEB & Companhia Energética de Brasília \\
\hline $\mathrm{CA}$ & Corrente Alternada \\
\hline $\mathrm{CC}$ & Corrente Contínua \\
\hline CEPLAN & Centro de Planejamento Oscar Niemeyer \\
\hline $\mathrm{d}$ & Diâmetro do Círculo Equivalente à Área da Seção Transversal da Haste \\
\hline DPS & Dispositivo de Proteção contra Surtos Elétricos \\
\hline DR & Dispositivo Residual \\
\hline $\mathrm{DF}$ & Distrito Federal \\
\hline EMC & Electromagnetic Compatibility \\
\hline EMI & Electromagnetic Interference \\
\hline ETI & Equipamento de Tecnologia da Informação \\
\hline FT & Faculdade de Tecnologia \\
\hline f & Freqüência \\
\hline $\mathrm{G}$ & Condutância \\
\hline GRACO & Grupo de Automação e Controle \\
\hline $\mathrm{Hz}$ & Hertz \\
\hline I & Corrente Elétrica \\
\hline IEC & International Electrotechnical Commission \\
\hline $\mathrm{k}$ & Quilo \\
\hline $\mathrm{L}$ & Indutância \\
\hline $\mathrm{L}$ & Comprimento da Haste \\
\hline $\mathrm{m}$ & Metro \\
\hline $\bar{M}$ & Mega \\
\hline $\mathrm{mm}$ & milímetro \\
\hline NBR & Norma Brasileira \\
\hline NMI & Núcleo de Multimídia e Internet \\
\hline $\mathrm{PE}$ & Protection Earth \\
\hline QGBT & Quadro Geral de Baixa Tensão \\
\hline QD & Quadro de Distribuição \\
\hline $\mathrm{R}$ & Resistência Elétrica \\
\hline $\mathrm{s}$ & Segundo \\
\hline SG & Serviços Gerais \\
\hline
\end{tabular}




\begin{tabular}{|c|c|}
\hline SPDA & Sistema de Proteção contra Descargas Atmosféricas \\
\hline $\mathrm{t}$ & Tempo \\
\hline TAP & Terminal de Aterramento Principal \\
\hline $\mathrm{U}$ & Tensão \\
\hline $\mathrm{U}_{\mathrm{B}}$ & Tensão de Contato \\
\hline $\mathrm{U}_{\mathrm{F}}$ & Tensão de Falta \\
\hline $\mathrm{U}_{\mathrm{P}}$ & Tensão de Passo \\
\hline $\mathrm{UnB}$ & Universidade de Brasília \\
\hline $\mathrm{USP}$ & Universidade de São Paulo \\
\hline $\mathrm{V}$ & Volt \\
\hline$Z$ & Impedância \\
\hline$\mu$ & Micro \\
\hline$\rho$ & Resistividade Aparente \\
\hline$\Omega$ & Ohm \\
\hline
\end{tabular}




\section{Capítulo 1 Motivação}

A motivação para este projeto está na necessidade de readequação das instalações elétricas de proteção que compõem a Faculdade de Tecnologia da Universidade de Brasília, uma vez que a norma NBR 5410/2004, na sua última versão sugere, de forma mais incisiva, aplicação de alguns conceitos e estruturas, a fim de prover qualidade e segurança mínimas às pessoas e equipamentos.

A esse motivo se soma o fato de a construção deste edifício datar do ano de 1978, ano em que a norma não se apresentava em seu padrão de qualidade atual, bem como o período transcorrido sem manutenção preventiva/corretiva coordenada, condições suficientes para a não garantia da integridade dos eletrodos componentes de um possível sistema de aterramento e eqüipotencialização existentes na edificação.

$\mathrm{O}$ aumento da quantidade de equipamentos utilizados, e conseqüentemente da carga instalada, como também do grau de sua sensibilidade, somados às questões citadas anteriormente, levam a um questionamento sobre o nível de segurança das instalações elétricas e à necessidade de revisão deste quesito tendo as normas nacionais vigentes como fundamentação para as indagações discorridas neste projeto. 
No acervo técnico da UnB e da própria equipe técnica de manutenção há relatórios apontando as imperfeições dos sistemas de proteção das edificações que compõem a UnB, indicando claramente a necessidade imediata de reestruturação. Neste estudo será feita uma fundamentação teórica, que confrontada com os dados de campo, permitirão uma análise do grau de criticidade do sistema de eqüipotencialização do prédio da FT.

A observação feita acerca desta situação, e do interesse no assunto, adquirido durante a disciplina Instalações Elétricas e de trabalhos desenvolvidos no Estágio, resultaram no tema deste trabalho.

As análises feitas ao final do desenvolvimento deste estudo levaram em consideração a situação atual deste sistema e as reais necessidades das instalações elétricas dadas as características físicas da edificação da FT, bem como de suas cargas, já que se trata de uma edificação antiga. 


\section{Capítulo 2}

\section{Introdução}

Na sua última versão, a NBR 5410/2004 apresentou, dentre outras, uma atualização na filosofia contra choques elétricos onde aponta um caráter inovador quanto à forma de aplicação e os resultados pretendidos. Esclarece as medidas de aplicação geral, apresentadas como regras, distinguindo-as daquelas que possuem aplicação mais específica. Neste contexto, a norma enfatiza os princípios da eqüipotencialização.

Outras normas nacionais, que possuem em sua essência a garantia da segurança das pessoas e das instalações, também se referem à eqüipotencialização. A NR-10, por exemplo, no item referente à Segurança de Projetos prescreve que "Sempre que for tecnicamente viável e necessário, devem ser projetados dispositivos de seccionamento que incorporem recursos fixos de eqüipotencialização e aterramento do circuito seccionado". Já, a IEC-50, que se trata de uma norma internacional, define Ligação Eqüipotencial como ligação elétrica que coloca massas e elementos condutores praticamente no mesmo potencial.

A intensidade de estudos nesta área se deve ao aumento da preocupação com a segurança das pessoas em relação às instalações elétricas, associado ao aumento da quantidade e sensibilidade dos equipamentos utilizados corriqueiramente, aumentando, conseqüentemente, a responsabilidade dos profissionais atuantes nesta área. 


\subsection{Metodologia}

O trabalho foi desenvolvido buscando-se três vertentes:

a) A legislação e sua aplicabilidade nos sistemas de aterramento e eqüipotencialização;

b) A situação da Faculdade de Tecnologia nos aspectos da instalação elétrica, identificandose os condutores neutro e de proteção (condutor PE - Protection Earth);

c) Propostas para a adequação das instalações quanto a eqüipotencialização, com a criação de um BEP (Barramento Equipotencial Principal);

Com o objetivo de dotar a FT de condições elétricos com segurança contra choques elétricos e danos a equipamentos por ausência de um referencial elétrico (BEP), a monografia foi elaborada em 07 capítulos.

No Capítulo 01, onde é apresentado o problema, é discutida a relevância do trabalho.

No Capítulo 02 são apresentados os fundamentos teóricos relacionados com eqüipotencialização, dando base teórica aos conceitos que serão tratados subseqüentemente no trabalho.

No Capítulo 03 encontram-se os fundamentos teóricos necessários para o entendimento do problema. São apresentados os conceitos de aterramento e eqüipotencialização, caracterizando-se seus princípios e aplicações à luz da NBR 5410/2004.

O Capítulo 04 descreve detalhadamente a situação das instalações da Faculdade de Tecnologia, expondo-se os dados de campo obtidos através de visitas, vistorias e interação com técnicos responsáveis.

Os conceitos de eqüipotencialização são discutidos no Capítulo 05 referindo-se às situações observadas nas instalações da FT e de seu histórico. 
No Capítulo 06 são apresentadas recomendações sobre alterações e melhorias mais imediatas a serem implementadas nas instalações.

Finalmente, no Capítulo 07, a pesquisa aponta as considerações finais com sugestões para futuros trabalhos.

\subsection{Fundamentação teórica}

A NBR 5410/2004 torna mais evidente as medidas de proteção contra choques como um todo, voltando o texto para o resultado que se quer alcançar.

O destaque do que é aplicação geral, assumindo caráter de regra, daquilo que é de uso mais restrito, configura-se como uma das novidades. Não manteve ombreada o que é regra, exceções, casos gerais e particulares.

Como já mencionado, o aumento da preocupação com a segurança das pessoas em relação às instalações elétricas, associado ao aumento da quantidade e da sensibilidade de equipamentos utilizados corriqueiramente foram motivo de estudos nesta área, aumentando, inclusive a responsabilidade dos profissionais atuantes nesta área. Somam-se a estes motivos qual a percepção dos riscos elétricos por parte do consumidor e o seu comportamento em face desses riscos.

Estes fatos e conseqüentes questionamentos culminaram então na complexidade das normas técnicas de segurança contra choques elétricos frisando as intenções gerais em suas aplicações. 


\subsubsection{Choque elétrico}

A eqüipotencialização visa de forma intrínseca a prevenção ao choque elétrico.

O choque elétrico, causado pela circulação de corrente elétrica pelo corpo de pessoas ou animais, é uma reação do organismo à perturbação que se manifesta no corpo com efeitos diversos que, além da intensidade da corrente elétrica, dependem da sua natureza, do tempo de exposição à corrente que percorre o corpo humano e do trajeto percorrido pela eletricidade ao longo do corpo.

Além da trajetória da corrente pelo corpo, outros fatores tais como a impedância e a tensão nominal do circuito determinam os efeitos de um choque elétrico.

O choque elétrico pode se dar em dois casos:

- Contato direto: contato de pessoas ou animais com partes vivas da instalação. [54]

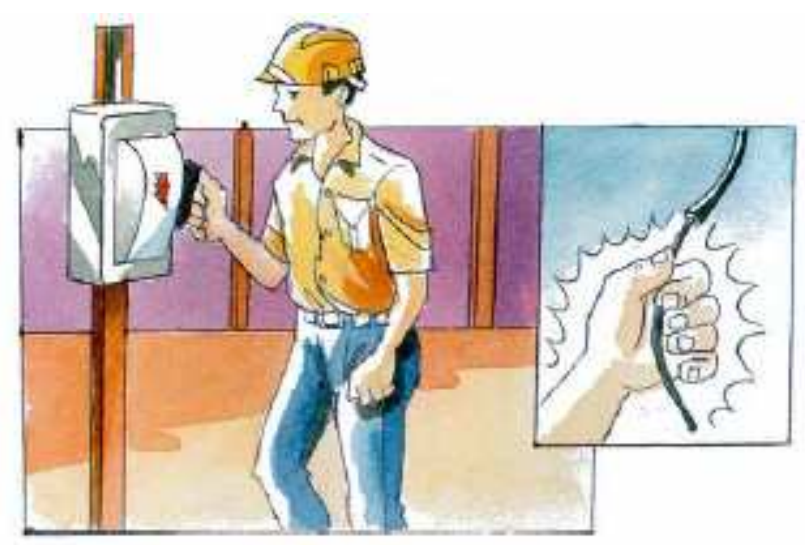

Figura 2.1 - Contato direto

FONTE: http://www.fundacentro.gov.br/ARQUIVOS/PUBLICACAO/I/SST_industria_da_construcao.pdf 
- Contato indireto: contato de pessoas ou animais com uma massa que ficou sob tensão em condições de falta. [54]

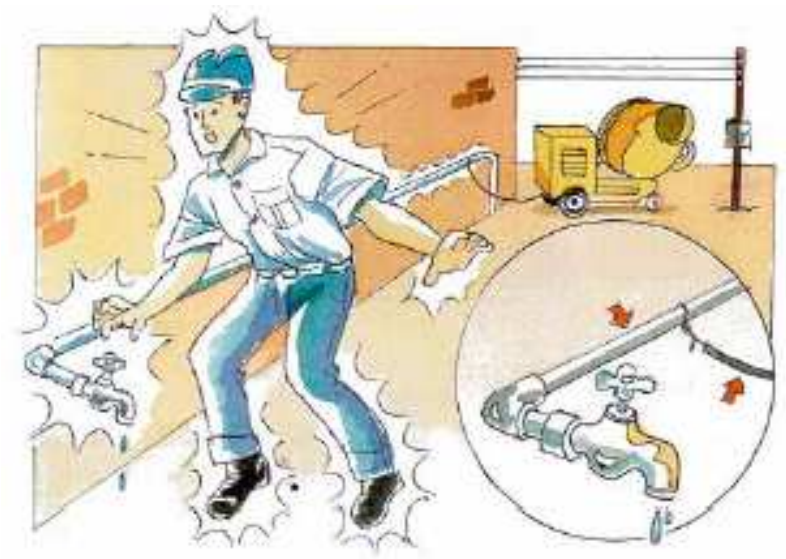

Figura 2.2 - Contato indireto

FONTE: http://www.fundacentro.gov.br/ARQUIVOS/PUBLICACAO/l/SST_industria_da_construcao.pdf

Na ocorrência de um choque elétrico o corpo humano ou animal participa como sendo uma carga, pois é condutor de corrente elétrica, não só pela natureza de seus tecidos como pela grande quantidade de água que contém, o que determina a impedância do corpo.

Os movimentos e respostas dos músculos do corpo humano são efeitos de impulsos nervosos de natureza elétrica, portanto, a superposição de uma corrente elétrica de considerável intensidade e freqüência causa contrações musculares involuntárias, que a depender da sua intensidade, são permanentes.

Conceituações fundamentais do choque elétrico bem como suas consequências estão bem detalhados em [4] e [15].

Nos equipamentos eletro-eletrônicos, a circulação de correntes de intensidade elevada ocasiona desgaste ou até mesmo a queima de dispositivos sensíveis, e queima de fusíveis.

Quando a corrente alcança um limite superior ao suportado pelo próprio fusível há queima de cabos, os quais não possuem dimensões e isolação suficientes para permitir passagem 
normal dessas correntes elevadas.

No caso de uma descarga atmosférica, a queima se deve a uma tensão elevada suficiente para romper a isolação do ar e de uma alta corrente que incorre na passagem de grande quantidade de elétrons no tempo.

\subsubsection{Níveis de proteção}

As normas que estabelecem as condições para garantia da segurança das pessoas e equipamentos, nas condições mais usuais de utilização, são a NBR 5410, para as instalações a baixa tensão, e a NBR 14039, para as instalações de média tensão.

Na versão de 2004 da NBR 5410, estabelecem-se nomes diferentes para classificar os níveis de proteção existentes, componentes de uma instalação elétrica:

- Proteção básica;

- Proteção supletiva;

- Proteção adicional.

A denominada proteção básica é aquela destinada a impedir contato direto com partes vivas perigosas em condições normais. Os choques ocorridos nestes casos são causados pela falha das medidas básicas de segurança ou por negligência ou imprudência do usuário.

A proteção supletiva é aquela destinada a oferecer proteção contra choques elétricos quando massas ou partes condutivas acessíveis tornam-se vivas de forma acidental. Portanto, se destina a preservar a segurança quando das falhas da proteção básica. Os choques ocorridos nestes casos são, dessa maneira, imprevisíveis e, conseqüentemente mais freqüentes.

A aplicação de ambas as proteções básica e supletiva é item mínimo exigido pela nova norma como o "princípio básico da proteção" que deve ser assegurado. Pode-se definir, portanto, 
que a proteção básica e a proteção supletiva são coadjuvantes.

A proteção adicional é, por sua vez, destinada a assegurar uma proteção contra contatos diretos ou indiretos no caso de falhas das medidas aplicadas ou de imprudência dos usuários. É importante frisar que a aplicação da proteção adicional não dispensa em nenhuma hipótese o emprego das medidas de proteção básica e supletiva.

\subsubsection{Proteção contra contatos indiretos}

Entende-se por contato indireto aquele em que o indivíduo mantém com uma determinada massa do sistema elétrico que, por falha, perdeu a sua isolação e permitiu que esse indivíduo ficasse submetido a um determinado potencial elétrico. [12]

O choque elétrico por contatos indiretos pode ocorrer por falhas de isolação básica ou por erros de projeto das instalações incluindo ausência ou deficiência de projeto do sistema de eqüipotencialização.

O contato indireto com partes energizadas pode ocorrer por meio de tensão de passo, tensão de toque e tensão de falta.

\subsubsection{Tensão de passo}

Tensão de passo é definida como parte da tensão de um eletrodo de aterramento à qual pode ser submetida uma pessoa nas proximidades do eletrodo, cujos pés estejam separados pela distância equivalente a um passo, como mostra a figura 2.3. 


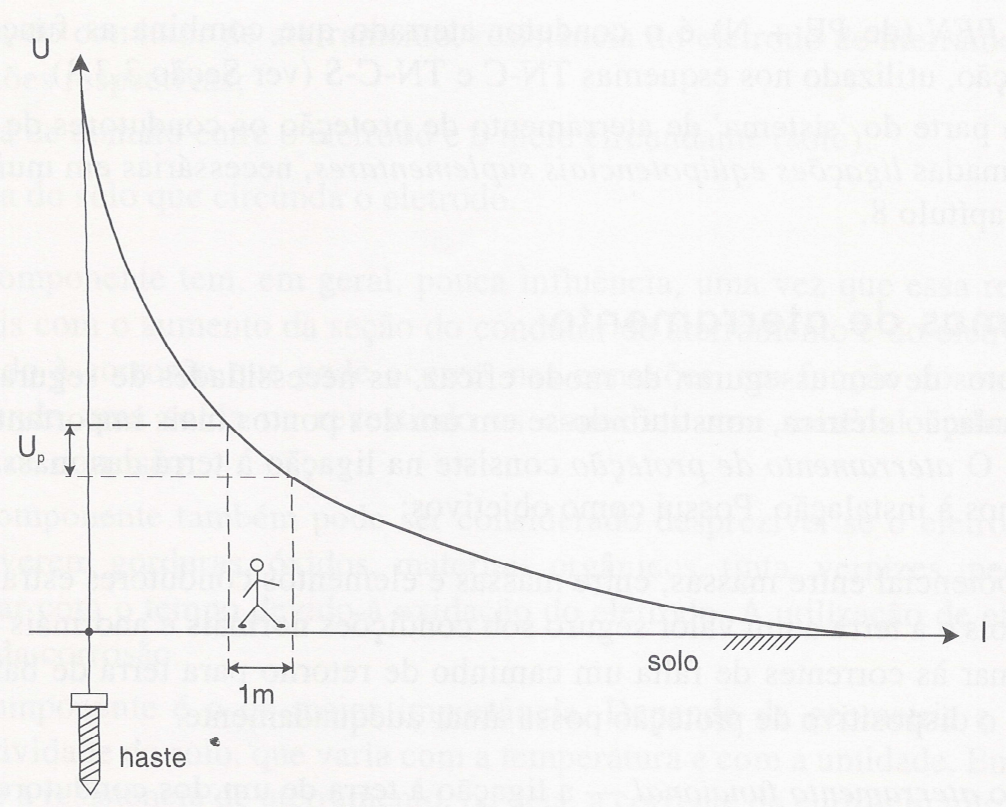

Figura 2.3 - Tensão de passo $\left(U_{P}\right)$

FONTE: Cotrim (2003)

\subsubsection{Tensão de contato ou de toque}

Tensão de contato ou de toque é a tensão que pode aparecer acidentalmente, quando do contato do indivíduo com partes metálicas energizadas acessíveis, quando da falha de isolação básica tendo como referência a terra (solo), como mostra a figura 2.4.

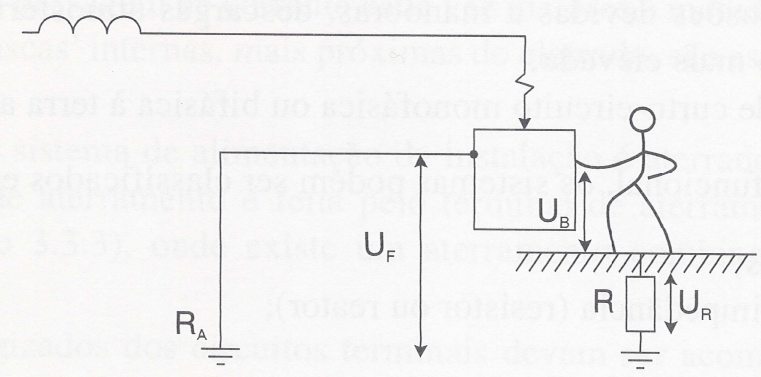

Figura 2.4 - Tensão de contato $\left(U_{B}\right)$

FONTE: Cotrim (2003) 


\subsubsection{Tensão de falta}

Tensão de falta é a tensão que aparece, quando há uma falha de isolamento, entre uma massa e um eletrodo de aterramento (um ponto cujo potencial não seja modificado pela energização da massa), como mostra a figura 2.5. Só é definida se o sistema possuir um ponto aterrado.

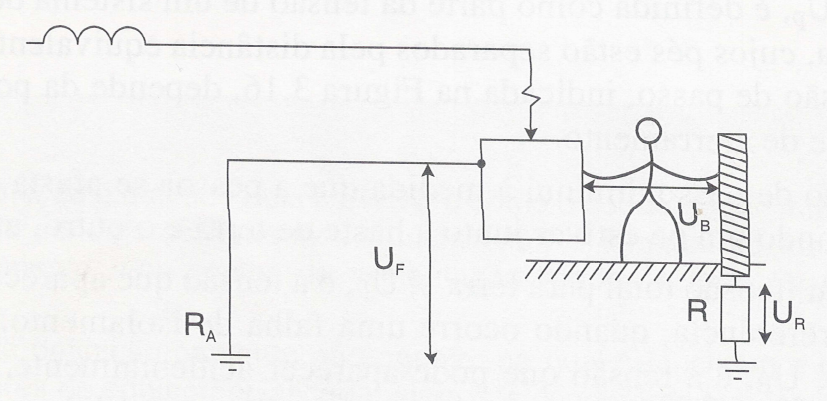

Figura 2.5- Tensão de falta $\left(U_{F}\right)$

FONTE: Cotrim (2003)

Pelos circuitos das figuras 2.4 e 2.5 tem-se:

$$
U_{F}=U_{B}+U_{R}[\mathrm{~V}]
$$

Pela expressão (1), temos que a tensão de contato $\left(U_{B}\right)$ é geralmente inferior à tensão de falta $\left(U_{F}\right)$. Considerando-se que o elemento condutor esteja no potencial da terra, onde $R=0$ e $U_{R}=0$, então $U_{F}=U_{B}$.

\subsubsection{Aterramento para descargas atmosféricas}

Descarga Atmosférica é uma descarga elétrica natural muito intensa que ocorre na atmosfera consistindo em um ou mais impulsos, chamados de raios (foto 2.1). 


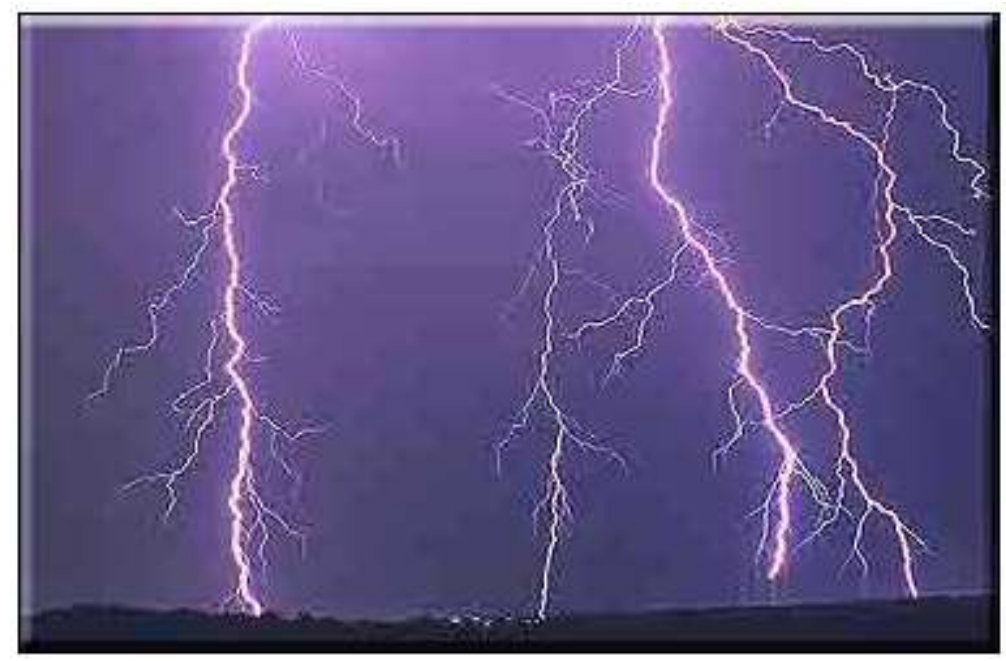

Foto 2.1 - Descargas Atmosféricas FONTE: http://www.raios.com.br

No que se refere às descargas atmosféricas, a eqüipotencialização visa evitar que tensões perigosas sejam geradas quando da queda de um raio nas proximidades da edificação ou nas suas estruturas.

O raio é um fenômeno de alta freqüência, chegando a $1 \mathrm{MHz}$. Nesta situação, um condutor com 10 metros de comprimento pode proporcionar uma diferença de potencial de 100 $\mathrm{kV}$, que, referenciado à terra, é uma tensão perigosa.

Dessa forma, um aterramento de segurança não é necessariamente um bom aterramento para descargas atmosféricas. Um aterramento para descargas atmosféricas pode ser diferente do aterramento de segurança do edifício, mas deve, logicamente, ser ligado a ele para fins de eqüipotencialização.

Todo sistema elétrico ou eletrônico deve ser referenciado à terra. O ponto de terra, neste caso, providencia uma referência comum para os circuitos dos sistemas. Para estes pontos, a referência de terra irá satisfazer apenas os requisitos funcionais. Estes sistemas são normalmente interconectados com a terra para proporcionar segurança às pessoas, não permitindo a presença de potenciais perigosos. Um exemplo típico é um terminal de computador, onde o fio verde (terceiro pino da tomada) é o ponto de referência. 
Normalmente, o aterramento de um sistema de proteção contra descargas atmosféricas é tratado como mencionado acima, mas na realidade, é diferente. Esse sistema representa um caminho de baixa impedância para o escoamento das cargas provenientes de descargas atmosféricas em direção ao solo.

Há experiências de casos em que o sistema de aterramento de um SPDA não funcionou satisfatoriamente, como ocorrência de descargas na instalação quando da circulação da corrente de descarga através do sistema de aterramento, devido a uma tensão muito elevada, ou casos em que o raio circula mais facilmente através de um canal não previsto do que pelo sistema de aterramento. Estes são casos típicos de inadequados sistemas de aterramento para descargas atmosféricas.

Como as descargas atmosféricas são fenômenos de alta frequiência, é importante que não somente a resistência de terra apresente valores baixos, mas sim a impedância de terra. Geralmente, o propósito é uma resistência baixa, sendo $10 \Omega$ um valor considerado aceitável pela norma 5419/2005 e, às vezes, o terra de segurança da edificação presente na instalação é utilizado diretamente com sistema de aterramento para descargas atmosféricas.

É importante frisar que o problema principal está na frente de onda do raio (onde a freqüência é mais elevada). A parte principal do conteúdo de energia da onda da descarga

atmosférica é liberada na faixa de frequiências de algumas dezenas de kHz, ou seja, nas frequiências mais baixas, e o tamanho dos condutores determinados nas normas suportam tal solicitação. 


\subsubsection{Resposta em freqüência}

O valor da impedância de aterramento é afetado diretamente pela forma e dimensões da malha que o compõem, e um aterramento longo e profundo não é necessariamente um bom sistema de aterramento para descargas atmosféricas, pois, nesta situação, a frequiência (altas frequiências) determina grandes variações desta impedância.

O condutor real é representado por duas características principais: resistência e impedância. A equação abaixo (2) representa essa relação:

$$
Z=\sqrt{R^{2}+(\omega L)^{2}}=\sqrt{R^{2}+(2 \pi f L)^{2}}[\Omega]
$$

Para correntes a baixas freqüências ou contínuas teremos $\mathrm{R}>\mathrm{L}$ e, a indutância pode ser desconsiderada.

A queda de tensão em um dado condutor será então definida pela Lei de Ohm $V=R . I$, onde I é o valor da corrente de surto. Dessa forma, o aumento da frequiência é um fator agravante na queda de tensão em condutores, no entanto, a intensidade do pulso de corrente é um fator mais agravante ainda, pois pode chegar à ordem de kA.

A queda de tensão sobre um condutor utilizado para eqüipotencialização pode reduzir substancialmente a eficácia da proteção.

Dentro deste conceito é imprescindível que o comprimento do condutor seja o menor possível, sem folgas desnecessárias. O principal fator a influenciar a indutância de um condutor é sua geometria.

De acordo com Sant'ana [30], o comportamento em alta frequiência não é afetado pelo material do eletrodo. O uso de determinados materiais, tais como aço revestido de cobre ou cobre é mais relacionado com as condições de corrosão do solo do que ao comportamento em relação às descargas atmosféricas. 
De acordo com Rousseau [23], em altas freqüências, um condutor com perfil retangular tem impedância até 10 vezes menor que um condutor com perfil cilíndrico de mesma seção transversal. Esse condutor com perfil retangular pode ser de aço ou de cobre, sendo que esse material, nessas freqüências, não altera a condução das correntes provenientes dos surtos. [30] As placas, apesar de mais eficientes para obtenção dos parâmetros de resistência e capacitância, podem ser caras, tornando a malha uma boa alternativa.

Na norma européia ENV 61024-1[21], há uma tentativa de limitar a impedância através da adição de regras de engenharia: “...a forma e as dimensões do sistema de eletrodos de aterramento são mais importantes do que o valor específico da sua resistência de terra. Entretanto, é recomendada em geral uma resistência de terra baixa”. [23]

Há equipamentos para medir o comportamento de sistemas de aterramento a altas freqüências (numa faixa entre $10 \mathrm{~Hz}$ a $1 \mathrm{MHz}$ ) e existem também algumas regras para projeção de um adequado sistema de aterramento para descargas atmosféricas. [23]

\subsubsection{Modelo numérico}

A fim de se considerar o parâmetro freqüência no projeto de malhas de aterramento, destinadas a proteção contra descargas atmosféricas, foi proposto um modelo matemático de condutor de aterramento.

Este modelo utiliza-se de um modelo de linha comum, onde os parâmetros por unidade de comprimento são descritos como uma resistência $(\mathrm{R})$, uma indutância $(\mathrm{L})$ e uma capacitância (C). A figura 2.6 abaixo representa o modelo. 


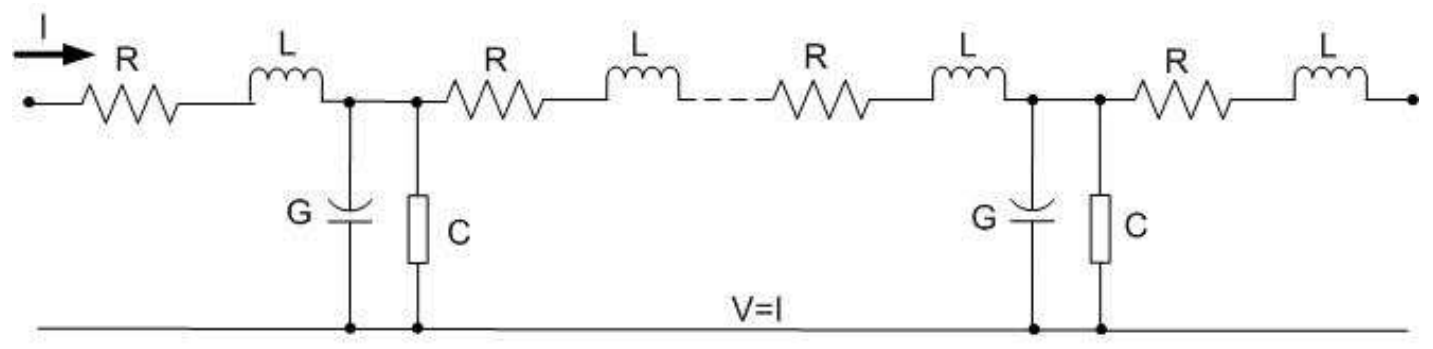

Terra

Figura 2.6 - Esquema do Modelo de Condutor de Aterramento

FONTE: Revista EM janeiro de 2004

A resistência $\mathrm{R}$ é a resistência do condutor de terra (geralmente de cobre), e é baixa por definição. Em altas freqüências, no entanto, o efeito pelicular determina circulação da corrente somente pela periferia do condutor, ficando claro, que para uma mesma seção um condutor chato apresentará, a altas freqüências, melhor comportamento que um redondo.

A impedância de onda no caso de um raio será de acordo com a equação (3):

$$
Z=\frac{\sqrt{R+j \omega L}}{\sqrt{G+j \omega C}}
$$

É necessário se ter um $\mathrm{Z}$ baixo, e para isso não é suficiente uma condutância G elevada (portanto, uma resistência de aterramento baixa), mas também uma capacitância elevada e uma indutância baixa.

A capacitância pode ser elevada com o aumento da superfície dos eletrodos (por exemplo, uma placa ou malha em vez de um único condutor). O aumento do contato do solo com os eletrodos também contribui para esse engrandecimento. A indutância por sua vez, pode ser diminuída utilizando-se vários condutores em paralelo em vez de um único condutor, de comprimento total equivalente. A resistência de ambos os sistemas será equivalente, desde que os condutores em paralelo sejam dispostos de forma a não interferir muito entre si. 


\section{Capítulo 3}

\section{O Aterramento e a Eqüipotencialização}

O sistema de aterramento é uma estrutura essencial à eqüipotencialização. Em um sistema de eqüipotencialização, está implícita a existência de aterramentos interligados que, por sua vez, deverão estar ligados direta ou indiretamente à instalação.

Os conceitos de aterramento e de eqüipotencialização, bem como seus princípios, serão explanadas nesse capítulo como importante subsídio para entendimento das condições atuais das instalações elétricas da Faculdade de Tecnologia e das readequações necessárias, no que concerne a este tema.

\subsection{Aterramento}

Na intenção de definir eqüipotencialização, a NBR 5410 na sua última versão foi cautelosa no uso da palavra "aterramento". Isso se deve ao fato de que no Brasil o uso indiscriminado do termo "aterramento" gerou noções até mesmo conflitantes; o sentido ficou reduzido ao de ligação à terra.

No sentido mais literal, aterramento é a arte de se fazer uma conexão com toda a "terra". 
A conexão terra é a interface entre o sistema de aterramento e o solo terrestre, e é por esta interface que é feito o contato elétrico entre ambos. Através desta interface passarão os eventos elétricos de e para o mencionado sistema.

O aterramento se aplica a dois fenômenos físicos: aos fenômenos naturais, que lida com a proteção contra raios, e aos fenômenos produzidos pelo homem, que visa à proteção das instalações elétricas. Essa é a principal medida de proteção contra contatos indiretos (com partes não-vivas da instalação), que se utiliza do princípio de eqüipotencialização e do seccionamento automático da alimentação, proporcionando atuação de fusíveis, disjuntores e dispositivos à corrente diferencial-residual.

O aterramento tem a finalidade de criar um caminho condutor de eletricidade para correntes geradas por ligações incorretas, descargas atmosféricas, transientes ${ }^{1}$ ou para escoamento de cargas acumuladas na carcaça de equipamentos, sem que qualquer destes eventos ofereça perigo às pessoas ou animais, assim como sensibilizar rapidamente os equipamentos de proteção, isolando as faltas à terra, fornecendo um caminho de baixa impedância para tais correntes.

O fenômeno de corrente de falta tem natureza eletrodinâmica: a corrente percorre sempre um caminho fechado incluindo a fonte e a carga. Na ocorrência de uma descarga atmosférica, o fenômeno é eletrostático: a corrente do raio circula pela terra para neutralizar as cargas induzidas no solo. A circulação dessas correntes cria gradientes de tensão e dá origem às tensões de passo e de contato.

Conforme dito anteriormente, o aterramento é relacionado também para a proteção contra geração de tensões quando do escoamento de correntes pela terra, seja ela gerada por uma descarga atmosférica, seja por um curto-circuito fase-terra.

Transientes ${ }^{1}$ são fenômenos eletromagnéticos rápidos. Os surtos também são transientes mas nem todo transiente é um surto. Estes fenômenos são responsáveis por causar interferência indesejada em muitos dispositivos e equipamentos elétricos, eletrônicos e de telecomunicação. 
Ilustrado na figura 3.1, um sistema de aterramento tem como atribuições:

Segurança de atuação da proteção;

Proteção das instalações contra descargas atmosféricas;

Proteção do indivíduo contra contatos com partes metálicas da instalação energizadas acidentalmente;

Uniformização do potencial em toda área do projeto, prevenindo contra lesões perigosas que possam surgir durante uma falta fase-terra;

Proteção de linhas de sinais e de equipamentos eletrônicos.

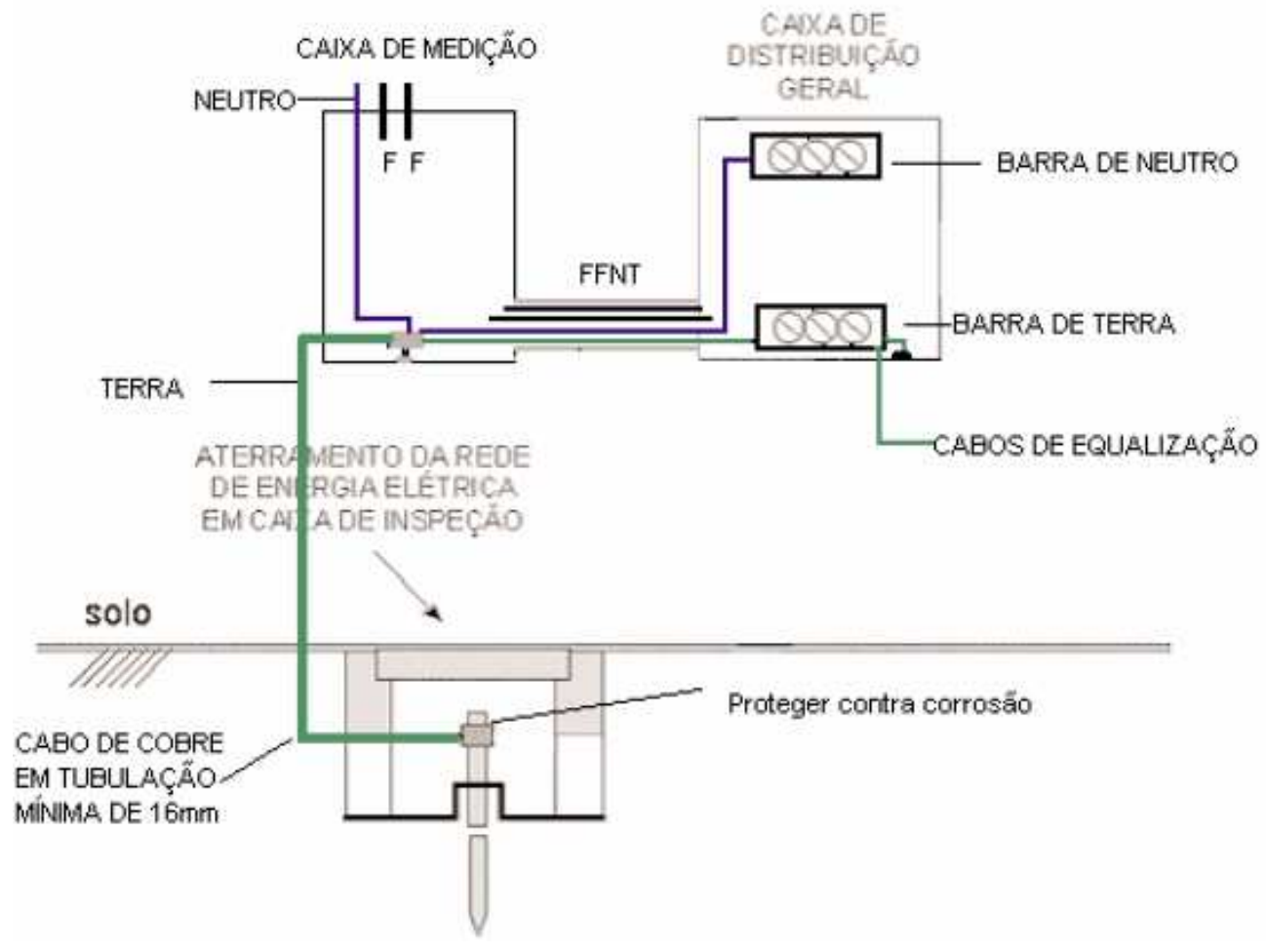

Figura 3.1 - Esquema Básico e Geral de um Aterramento

FONTE: http://www.fisica-potierj.pro.br/Sobre_Raios_\%20e_Outros/Aterramento.pdf 
Percebe-se na figura que a caixa que aloja a medição está conectada ao aterramento. No ponto de conexão, onde se constitui um nó elétrico, o neutro e o condutor de aterramento (PE) estão interligados. Deste ponto em diante, o neutro e o PE seguem separados caracterizando um esquema TN-S.

\subsection{1. $\quad$ Eletrodo}

A todos os condutores enterrados no solo e ligados eletricamente à terra a fim de constituir um aterramento dá-se o nome de eletrodo de aterramento. Estes componentes podem ser especificamente fabricados para tal função, como hastes e chapas de cobre, ou serem eletrodos naturais, que são elementos metálicos presentes no volume a proteger, que podem constituir um trajeto de corrente, tais como partes metálicas da edificação.

A norma NBR 5410 trata o aterramento como uma infra-estrutura, uma parte integrante da edificação, e não algo que deva prover somente à instalação elétrica, e que deve ser constituída preferencialmente pelas próprias armaduras do concreto das fundações, ou, no mínimo, por um anel metálico enterrado circundando o perímetro da edificação.

Os condutores que conectam as massas e os elementos condutores estranhos à instalação (tais como tubulações metálicas de água e esgoto, de sistema de ar-condicionado etc) entre si e o barramento de eqüipotencialização principal são denominados condutores de proteção. Incluemse, portanto, em condutores de proteção tanto os condutores de aterramento quanto os condutores de eqüipotencialização.

A utilização de hastes enterradas interligadas por um condutor nu, circundando a edificação, para redução da resistência de terra, é uma solução muito comum e eficiente recomendada pela norma utilizando-se de eletrodos convencionais (anexo A). A colocação destes eletrodos visa também evitar a ocorrência da tensão de passo, pois a superfície equipotencial proporcionada pelo aterramento irá garantir que apareçam gradientes de potencial aceitáveis entre pontos acessíveis às pessoas quando da circulação dessas correntes. 
Quando uma corrente é injetada num eletrodo de aterramento aparecem a redor dele e ao longo do solo, gradientes de potencial distribuídos radialmente conforme figura 3.2. Esses gradientes têm valores mais elevados nas proximidades do eletrodo e diminuem com a distância. A zona de influência do eletrodo é então determinada pela região onde o potencial varia com a injeção de corrente.

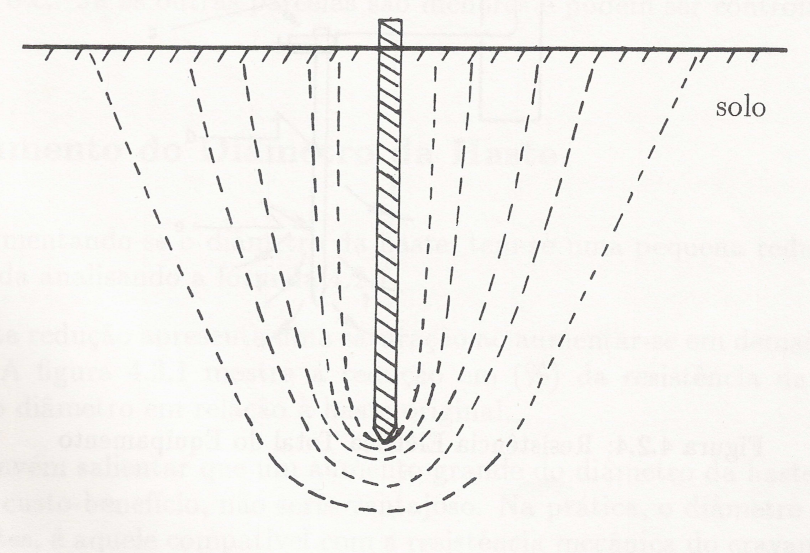

Figura 3.2 - Superficies Equipotenciais de Uma Haste Cravada em Solo Homogêneo FONTE: Kindermann (1995)

É importante observar que o aumento da quantidade de eletrodos é benéfico até um certo limite, determinado em função do seu comprimento e da distância entre eles.

A eficiência de um sistema de eletrodos verticais em paralelo em função da sua quantidade e da distância entre eles é ilustrada na figura 3.3. 


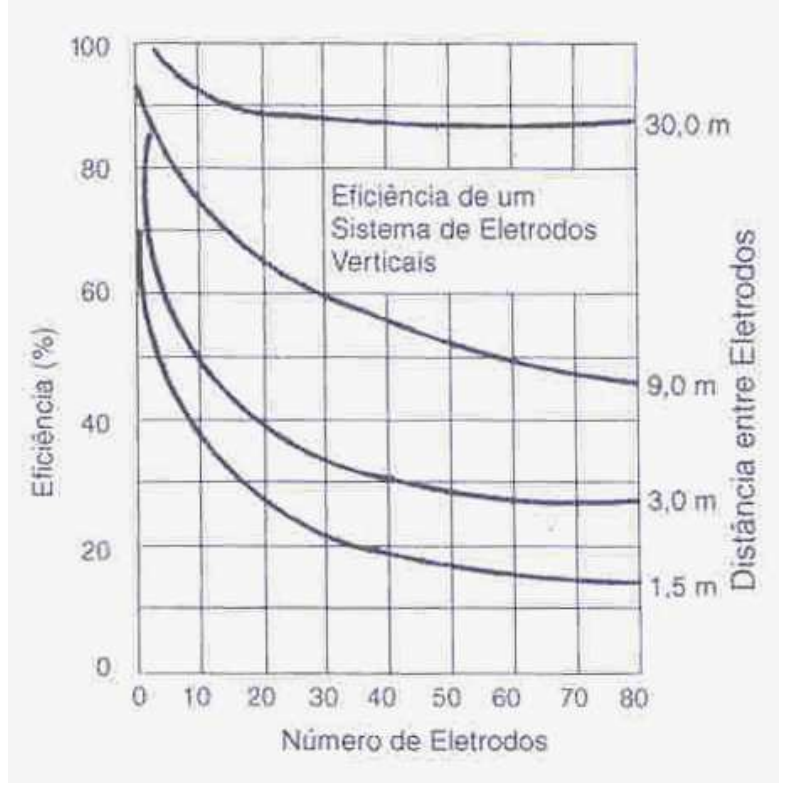

Figura 3.3 - Eficiência dos Eletrodos

FONTE: Mamede (2002)

A distância mínima entre eletrodos contíguos deve equivaler ao comprimento da haste do eletrodo. A figura 3.4 mostra as linhas equipotenciais resultantes do conjunto formado por duas hastes, impedindo que na circulação de corrente de falta ou de descarga atmosférica haja geração de potenciais perigosos no solo.

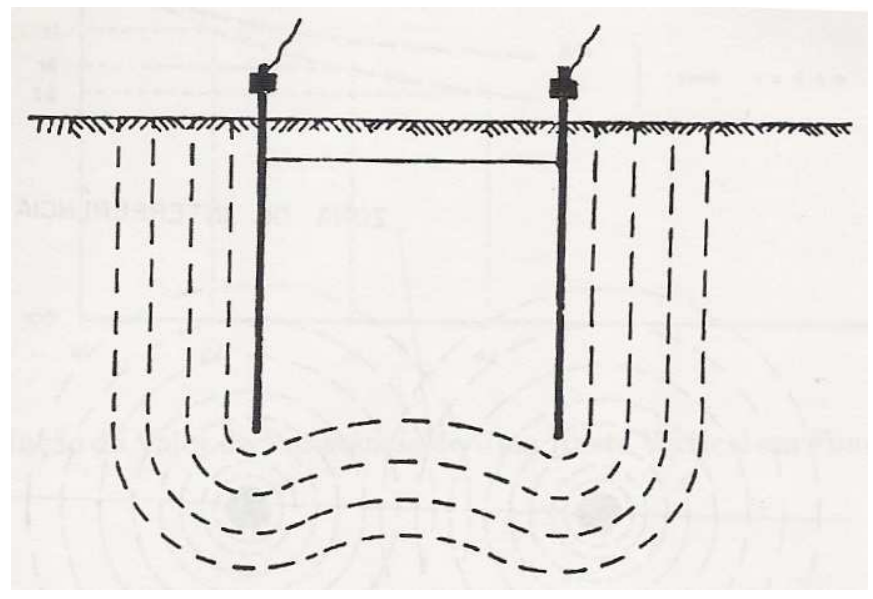

Figura 3.4 - Superficies Equipotenciais de Duas Hastes

FONTE: Kindermann (1995) 
No caso de hastes localizadas entre si a uma distância inferior ao seu comprimento efetivo, quando percorridas por uma elevada corrente de falta, há um aumento na sua impedância mútua. Isso se deve à ocorrência da zona de interferência das linhas equipotenciais, representado na figura 3.5, que causa um bloqueio do fluxo de corrente de cada haste, resultando numa maior resistência de terra individual. Além de provocar um aumento da resistência equivalente, a aplicação de hastes em excesso representa desperdício de material.

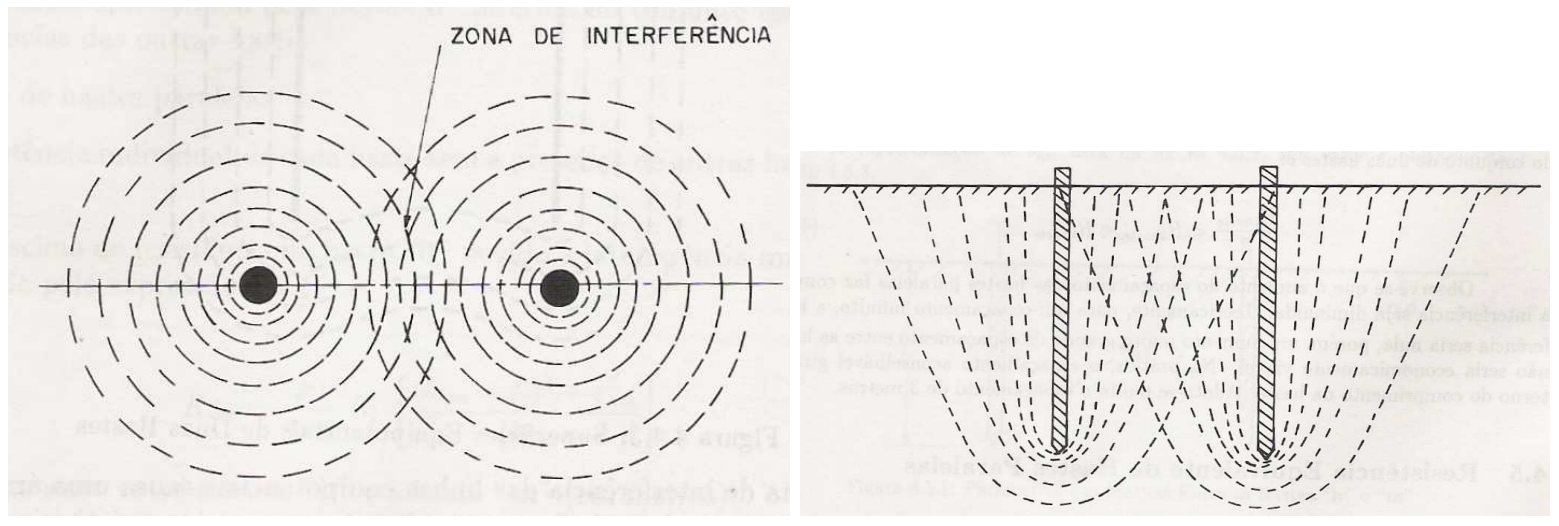

Figura 3.5 - Zona de Interferência nas Linhas Equipotenciais de Duas Hastes

FONTE: Kindermann (1995)

Um aterramento mais profundo não é necessariamente mais eficiente; deve-se considerar o tipo de solo e sua estratificação. Alguns solos são rochosos ou argilosos nas camadas mais inferiores e portanto, sendo mais úmidas suas camadas superiores.

Com relação aos materiais empregados na instalação, a Associação Brasileira de Normas Técnicas (ABNT), preocupa-se com a qualidade dos eletrodos utilizados. Em casos de ambientes agressivos, a NBR 5419 recomenda a utilização de metais nobres, descartando o uso do alumínio ou elementos ferrosos. O cobre, por ser mais durável e suscetível à umidade, conquistou os profissionais da área e se tornou o material mais usado nestas aplicações.

O cobre é o metal mais indicado nos SPDA, pois é fácil de instalar e eficiente na proteção contra uma descarga atmosférica, com reduzidas perdas de suas características pelas ações do tempo. Isso garante a continuidade das especificações na proteção contra as descargas atmosféricas. 


\subsubsection{Resistência de terra de uma haste}

Uma haste cravada verticalmente em um solo homogêneo, conforme mostra a figura 3.6 possui uma resistência determinada pela seguinte fórmula:

$$
R_{1 \text { haste }}=\frac{\rho_{a}}{2 \pi L} \ln \left(\frac{4 L}{d}\right)[\Omega]
$$

Por esta fórmula é possível concluir que, considerando-se as hastes-padrão existentes no mercado, dificilmente um aterramento contendo uma única haste fornecerá o valor de resistência desejado.

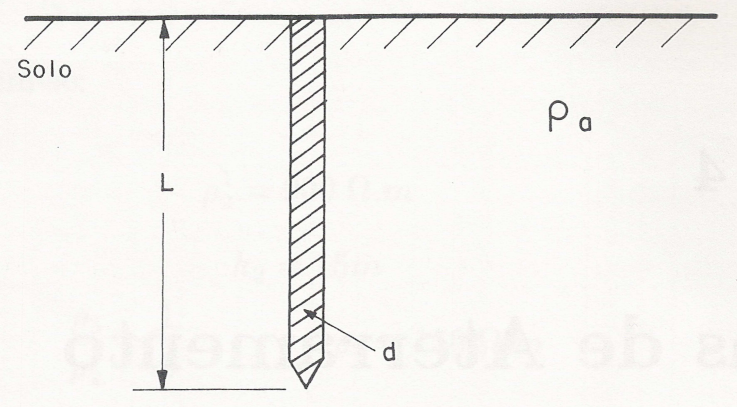

Figura 3.6 - Haste Cravada no Solo

FONTE: Kindermannn (1995)

\subsubsection{Aterramento "isolado"}

A aplicação do conceito de malhas de aterramento isoladas tem a finalidade de evitar que distúrbios originados em equipamentos de potência atinjam os aterramentos que servem a outros equipamentos mais sensíveis. Este conceito era amplamente aceito e empregado, fazendo-se separação dos aterramentos para equipamentos eletrônicos em relação aos demais aterramentos de uma dada instalação, a fim de se obter um terra de referência individual.

No entanto, por questões das dimensões para as áreas de uma instalação, é praticamente 
impossível evitar-se um acoplamento condutivo significativo entre os diferentes aterramentos, permitindo que algumas ocorrências, tais como curto-circuitos, originem valores consideráveis de tensão nessa "referência de potencial".

Mesmo numa situação em que seja possível se posicionar aterramentos sensíveis a grandes distâncias dos demais, é necessário uma análise do efeito de eventuais descargas atmosféricas próximas aos aterramentos. Nessas eventualidades, os equipamentos sensíveis ${ }^{2}$ que se deseja proteger podem ser submetidos a elevados valores de diferença de potencial. No caso de geração de valores de tensão entre aterramentos superiores a um determinado limite, ocorre disrupção e os aterramentos tornam-se eletricamente conectados.

A prática de conexão de equipamentos sensíveis distribuídos pela instalação, aos aterramentos isolados, pode originar loops de terra, que na existência de diferença de potencial entre as regiões onde se encontram estes aterramentos, pode ocorrer fluxo significativo de correntes nas blindagens dos cabos que conectam os equipamentos. Nem sempre esses cabos estão projetados para suportar tais correntes.

Essa filosofia de aterramentos isolados é, atualmente, raramente empregada, embora ainda se encontre aplicações em que as terminações de terra do sistema de proteção contra descargas atmosféricas encontram-se isoladas do sistema de aterramento restante. Uma prática possível é a conexão dos aterramentos por meio de um conjunto de centelhadores ${ }^{3}$, ou "gaps".

Equipamentos sensíveis ${ }^{2}$ são equipamentos que têm seu funcionamento e integridade comprometidos por pequenas variações na rede de alimentação.

Centelhador ${ }^{3}$ é um dispositivo que opera como uma chave dinâmica comandada por tensão. 


\subsubsection{Configurações de aterramento}

Os sistemas de aterramento podem possuir diversos configurações:

- Hastes alinhadas;

- Hastes em triângulo;

- Hastes em quadrado vazio;

- Hastes em quadrado cheio;

- Hastes em círculo;

- Fios ou cabos enterrados no solo em diversas configurações: extendido em vala comum, em cruz, em estrela ou ainda, quadriculados, formando uma malha de terra.

O tipo de configuração do sistema de aterramento a ser adotado depende do local, do custo e da resistência da terra mais circunvizinha aos eletrodos.

\subsection{Equiipotencialização}

A eqüipotencialização é o ato de fazer com que entre dois ou mais corpos não haja diferença de potencial elétrico.

A eqüipotencialização em uma instalação elétrica é um recurso usado na proteção contra choques elétricos e na proteção contra sobretensões e perturbações eletromagnéticas. A eqüipotencialização reúne todos os elementos metálicos da edificação, bem como os condutos de energia e sinal que entram e saem da edificação. Sendo assim, todos os pontos devem ter o mesmo potencial elétrico. 
A esse respeito, a nova versão da NBR 5410 se apresentou mais pedagógica. A alteração do nome TAP (terminal de aterramento principal) para BEP (barramento equipotencial principal), por exemplo, reflete melhor o papel deste elemento dentro da instalação, que é o de eqüipotencialização. Por tudo isso, em uma dada edificação, o aterramento é necessariamente único e a eqüipotencialização é ampla e geral.

No tratamento sobre a eqüipotencialização principal é visível a preocupação da norma com os princípios mais atuais relacionados com a segurança e com o bom funcionamento dos sistemas.

Com foco na eqüipotencialização, algumas disposições já existentes tornaram-se mais categóricas na NBR 5410/2004, tomando caráter de prescrições ditando:

- todas as massas de uma instalação devem estar ligadas a condutores de proteção (exceto aqueles objetos de outra proteção que não o seccionamento automático) (item 5.1.2.2.3.1)

- todo circuito deve dispor de condutor de proteção em toda sua extensão (item 5.1.2.2.3.6)

- toda edificação deve ser provida de uma infra-estrutura de aterramento, constituída, preferencialmente, pelas próprias armaduras de concreto das fundações, ou, no mínimo, por um anel metálico enterrado circundando o perímetro da edificação (item 6.4.1.1.1);

- toda edificação deve ser provida de uma eqüipotencialização dita principal e tantas equipotencializações suplementares (eqüipotencialização locais) quantas forem necessárias, para fins de proteção contra choques e/ou de compatibilidade eletromagnética. A eqüipotencialização principal deve abranger todos os elementos condutivos (da edificação, das utilidades, das linhas externas), os condutores de proteção da instalação elétrica, o eletrodo de aterramento da própria edificação, etc. (itens 5.1.2.2.3.2 e 6.4.2.1); 
A norma NBR 5410/2004 relata que, no âmbito de uma edificação, o aterramento é necessariamente único e a eqüipotencialização ampla, geral e irrestrita. Conseqüentemente, todas as massas metálicas da instalação situadas em uma mesma edificação estarão necessariamente vinculadas à eqüipotencialização principal da edificação e, dessa forma, a um mesmo e único eletrodo de aterramento.

A palavra "vinculadas" não se refere estritamente à existência de uma ligação direta, mas sim, que as massas estão integradas a uma mesma eqüipotencialização e, conseqüentemente a um mesmo eletrodo de aterramento, através de condutores de proteção, com o menor percurso possível. Neste sentido, procura-se obter valores muito reduzidos para a indutância e resistência existentes nessas ligações.

Como a configuração para um sistema de aterramento em geral é constituída por vários aterramentos locais, existirão tantas conexões elétricas entre os diferentes aterramentos locais, que a densidade de corrente resultante nos vários caminhos não será capaz de causar danos aos condutores responsáveis por estas ligações. Adicionalmente, esta prática de grande quantidade de conexões determina menores valores para a impedância de aterramento. Assim, os elevados valores das capacitâncias do sistema, bem como os valores reduzidos das resistências e indutâncias, asseguram que os níveis de tensão induzida (por meio dos efeitos capacitivo, condutivo e indutivo) se limitem a níveis aceitáveis.

$\mathrm{Na}$ presença de equipamentos sensíveis, os aterramentos locais são geralmente constituídos por malhas reticuladas, que atuam como uma malha de terra de referência (figura 3.7). 


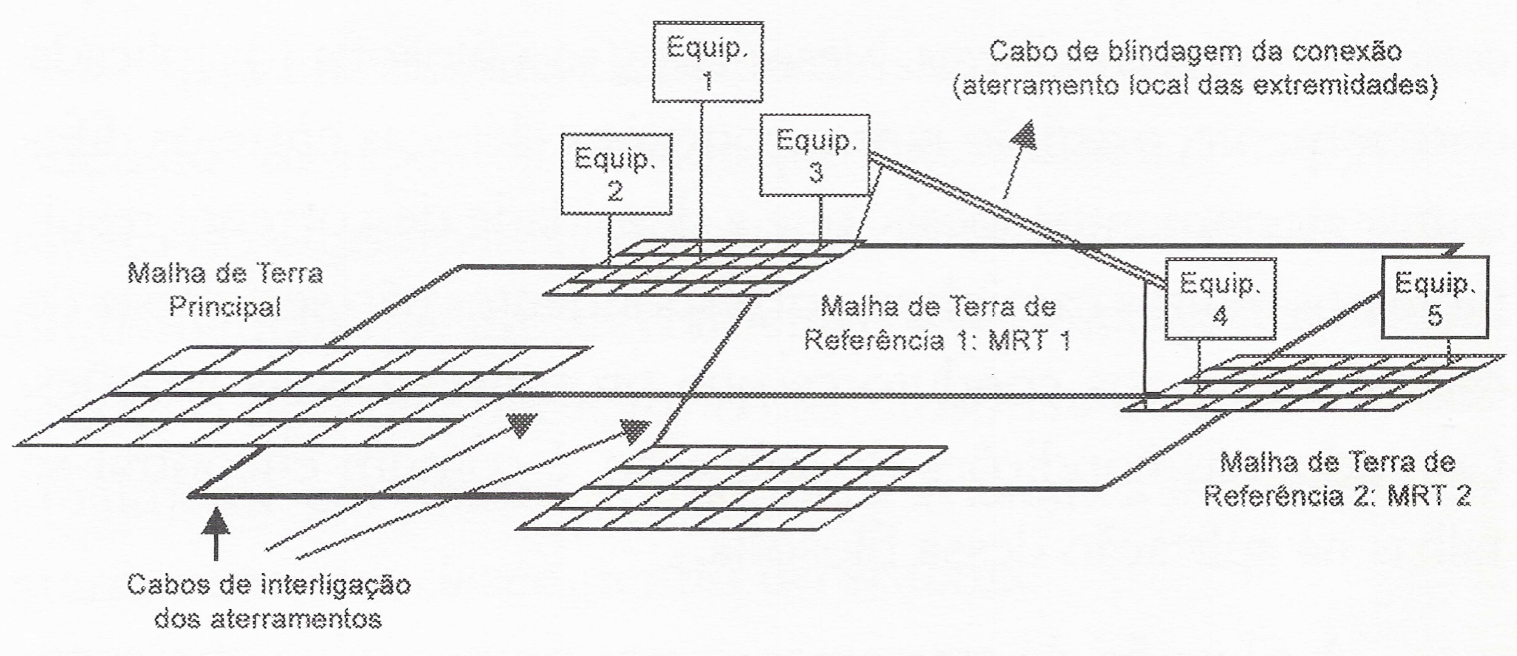

Figura 3.7 - Esquema de Representação de Aterramento com Eqüipotencialização

FONTE: Filho (2005)

\subsubsection{Eqüipotencialização principal}

O sistema de aterramento serve a vários sistemas de proteção distintos, mas que formem uma unidade. Em uma dada edificação deve ser realizada uma eqüipotencialização principal. Tal unificação visa a eqüipotencialização entre todas as proteções que constituem um sistema de aterramento, ou seja, entre as estruturas metálicas e/ou condutoras da edificação.

A conexão de todas as massas a um mesmo e único eletrodo de aterramento determina a eqüipotencialização dessas massas para se evitar o aparecimento de tensões perigosas que representem risco às pessoas e aos equipamentos e estruturas do sistema elétrico.

A eqüipotencialização visa impedir geração de descargas laterais causadas por diferenças de potencial entre a corrente que percorre o condutor e objetos próximos. A aplicação de tal conceito visa também criar vários caminhos para escoamento de possíveis correntes de falta ou de fuga. A esse ponto de convergência dos componentes do sistema de aterramento dá-se o nome de barramento equipotencial principal (BEP), o qual, por sua vez, estará conectado à terra por 
ponto único por meio de um condutor de aterramento.

Toda edificação deve possuir uma eqüipotencialização dita principal e de várias equipotencializações locais quanto forem necessárias. Todos os elementos condutivos, os condutores de proteção da instalação, o eletrodo de aterramento da edificação devem integrar a eqüipotencialização.

\subsubsection{Barramento equipotencial principal}

O barramento equipotencial principal é constituído de uma barra de cobre, que deverá ser instalada, segundo prescreve a norma, junto ao ponto de entrada da alimentação e o mais próximo do nível do solo.

Os elementos incluíveis, direta ou indiretamente, na eqüipotencialização principal são mostrados na figura 3.8.

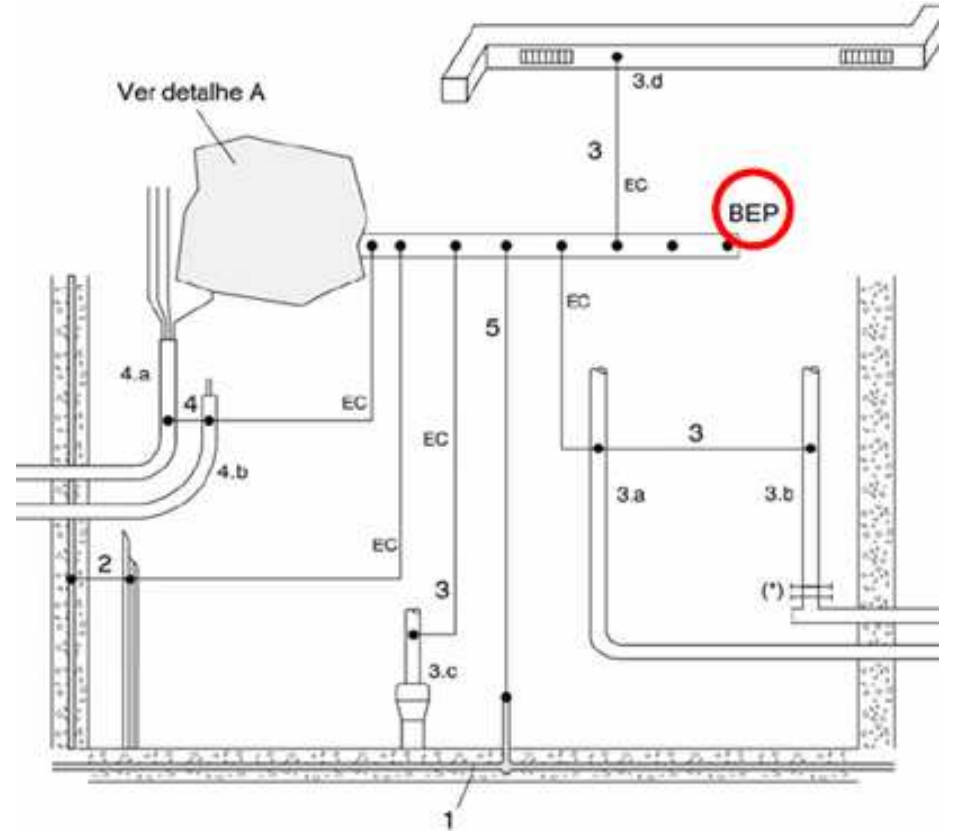

Figura 3.8 - Eqüipotencialização Principal numa Situação Hipotética FONTE: NBR 5410/2004 Anexo G 
Legendas:

BEP - barramento de eqüipotencialização principal;

EC - condutor de eqüipotencialização;

1 - eletrodo de aterramento (embutido nas paredes);

2 - armaduras de concreto armado e outras estruturas metálicas da edificação;

3 - tubulações metálicas de utilidades, bem como os elementos estruturais metálicos a elas associados;

Por exemplo:

$$
\begin{aligned}
& \text { 3.a - água } \\
& 3 . b \text { - gás } \\
& \text { 3.c - esgoto } \\
& \text { 3.d - ar-condicionado }
\end{aligned}
$$

4 - condutores metálicos, blindagens, armações, coberturas e capas metálicas de cabos;

4.a - linha elétrica de energia

4.b - linha elétrica de sinal

5 - condutor de aterramento principal.

O BEP deve estar localizado no ponto de entrada da edificação (por definição, ponto onde os condutores das linhas externas penetram na edificação).

Todos os elementos acessíveis potencialmente condutores de eletricidade dentro de uma instalação, sejam eles ou não destinadas à condução de corrente, devem ser conectados ao barramento de eqüipotencialização de forma a evitar circulação perigosa de correntes.

Com isso, a pessoa que acessar uma parte condutora submetida à tensão acidentalmente estará sobre uma superfície equipotencial, o que fará com que desapareça o risco inerente à tensão de contato, de falta ou passo.

\subsubsection{Elementos conectados ao BEP}

Os elementos que podem e devem ser incluídos na eqüipotencialização principal, são relacionados no anexo G da norma NBR 5410/2004, que define os aspectos de grande relevância, 
tais como a eqüipotencialização principal em que todos os elementos concentram-se aproximadamente num mesmo ponto e quando não se concentram ou não são acessíveis num mesmo ponto da edificação (figura 3.9).

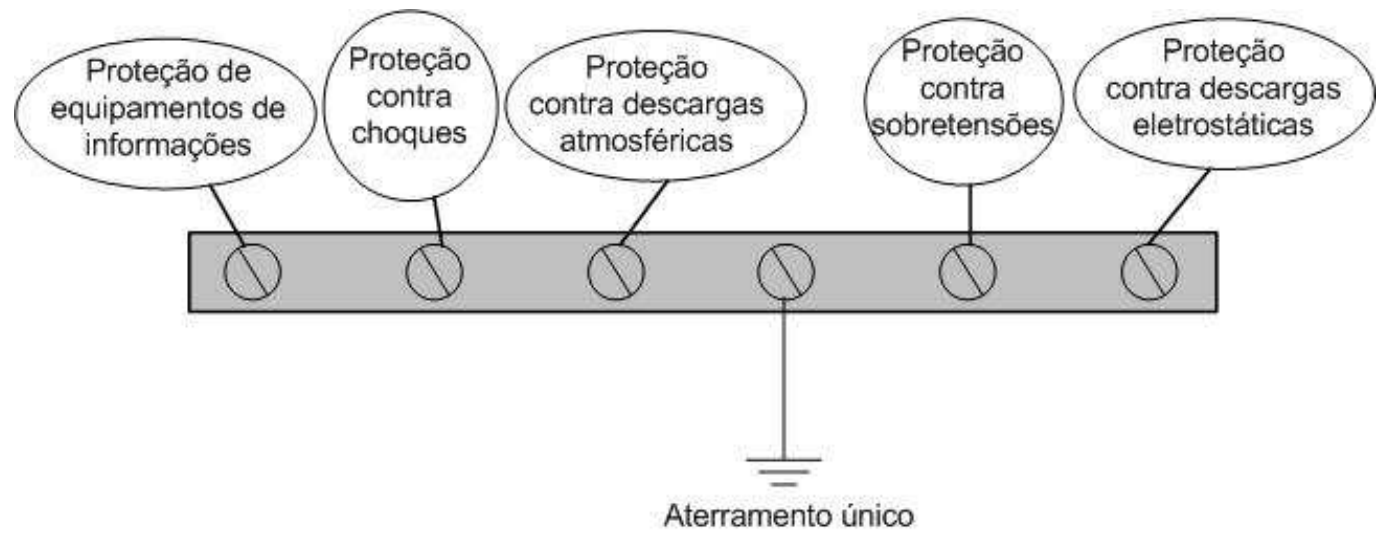

Figura 3.9 - Barramento Equipotencial Principal

FONTE: http://www.procobre.org/pr/pdf/pdf_pr/03_aterrame.pdf, Modificado por Pesquisadoras do Projeto

Pode haver uma eqüipotencialização principal para cada edificação que compõe uma dada propriedade. Se elas tiverem a uma distância de no máximo $10 \mathrm{~m}$ e possuírem linhas elétricas de origem comum, ou se o eletrodo principal de cada uma delas for interligado, elas serão consideradas eletricamente integradas. Caso contrário, as equipotencializações principais devem ser individuais.

A norma prescreve materiais, padrões e dimensões mínimas para os eletrodos de aterramento, assim como suas formas de conexão a fim de que estes resistam às intempéries e às condições mecânicas a que podem ser submetidos no tempo.

Conforme exemplificado na figura 3.8, a eqüipotencialização principal deve reunir determinados elementos metálicos da edificação. Os seguintes elementos são ligados eletricamente ao BEP:

- Massas estruturais da edificação (armaduras de concreto armado e outras estruturas 
metálicas);

- Massas das utilidades: tubulações metálicas de água, gás combustível, sistemas de arcondicionado, esgoto etc.;

- Condutores metálicos de linha de energia e de sinal que entram e/ou saem da edificação;

- Condutores de proteção das linhas de energia e de sinal que entram e saem da edificação;

- Blindagens, armações, coberturas e capas metálicas de cabos das linhas de energia e de sinal;

- Condutores de interligação provenientes de eletrodos de aterramento de edificações vizinhas, no caso em que essa interligação for necessária ou recomendável;

- Condutores de interligação provenientes de outros eletrodos de aterramento porventura existentes ou previstos no entorno da edificação;

- Condutor neutro da alimentação elétrica, salvo se não existente ou se a edificação deva ser alimentada em esquema TT ou IT;

- Condutor de proteção principal da instalação elétrica (interna) da edificação;

- Barramentos suplementares.

Como mencionado acima, a norma admite, e aconselha, que canalizações de água e esgoto e de outras utilidades sejam também elementos conectados para eqüipotencialização. Com isso, qualquer que seja o esquema de aterramento (TT, TN ou IT), a instalação deverá possuir um sistema de aterramento para proteção constituído por todos os elementos acima descritos. As conexões dos elementos ao BEP não precisam, no entanto, ser necessariamente de forma direta quando as distâncias elétricas não permitirem. 


\subsubsection{Eqüipotencialização suplementar ou eqüipotencialização local}

O barramento de eqüipotencialização local (BEL) é destinado a servir de via de interligação de todos os elementos incluíveis numa eqüipotencialização suplementar.

A realização de equipotencializações suplementares se faz necessária para fins de proteção contra choques ou por razões funcionais, onde contempla a prevenção contra perturbações eletromagnéticas. Como o próprio nome sugere, trata-se de uma proteção adicional, para compensar dificuldades no provimento da medida de caráter geral ou para compensar sua insuficiência em locais ou situações em que os riscos de choque elétrico são maiores ou suas conseqüências mais perigosas.

\subsubsection{Eqüipotencialização e compatibilidade eletromagnética}

A interferência eletromagnética (EMI - Electromagnetic Interference) é um campo ou onda elétrica e/ou magnética que pode ou não alterar o funcionamento ou danificar um equipamento, dispositivo ou aparelho. As descargas atmosféricas, que se tratam de fenômenos em altas frequiências, são exemplos de causas naturais de EMIs. São também tipos de perturbações eletromagnéticas: campos eletromagnéticos, perturbações transitórias, surtos de tensão e de corrente, harmônicas, desequilíbrio da tensão trifásica, flutuações de tensão, quedas de tensão e interrupções momentâneas.

A convivência de equipamentos em diversas tecnologias diferentes, somada à inadequação das instalações facilita a emissão de energia eletromagnética e com isto pode-se ter problemas de compatibilidade eletromagnética (EMC - Electromagnetic Compatibility), que é a habilidade de um equipamento funcionar satisfatoriamente sem interferir eletromagneticamente nos equipamentos próximos e ser imune à interferência externa de outros equipamentos e do ambiente.

O conceito de compatibilidade entra no contexto da coexistência cada vez maior de várias instalações em uma edificação, como a instalação de potência, os circuitos de sinais e o sistema 
de proteção contra descargas atmosféricas. O bom funcionamento de cada um deles é imprescindível, havendo, portanto, a necessidade de que não haja interferência entre eles.

O maior problema causado pela EMI são as situações esporádicas e que degradam aos poucos os equipamentos e seus componentes. Diversos problemas podem ser gerados pela EMI, por exemplo, em equipamentos eletrônicos, provocando falhas na comunicação entre dispositivos de uma rede de equipamentos e/ou computadores, alarmes gerados sem explicação, atuação em relés sem haver comando para isto e, queima de componentes eletrônicos etc.

Existem três caminhos de EMI entre a fonte e o dispositivo a ser influenciado:

- irradiação - A EMI irradiada se propaga a partir da fonte, através do espaço, para o dispositivo a ser influenciado.

- condução - Os ruídos utilizam algum meio físico para atingir o circuito que interferem (cabeamento, condutores etc). O meio conduzido pode envolver qualquer cabo de alimentação, entrada de sinal e terminais de terra de proteção. Geralmente, o meio físico inicial é a linha de distribuição de energia, que recebe toda sorte de interferência devido à complexidade e tamanho da malha elétrica e porque alimenta diversos tipos de equipamentos. O ruído aí presente se propaga facilmente pelas linhas de fase e neutro até o aparelho no qual interfere.

- indução - ocorre quando dois circuitos estão magneticamente acoplados.

As perturbações conduzidas normalmente estão na faixa de $10 \mathrm{kHz}$ a $30 \mathrm{MHz}$, que são características de descargas atmosféricas, e se classificam em:

- modo-comum - aparece entre os condutores vivos e os elementos do aterramento. A corrente e tensão de modo comum se propagam simultaneamente no mesmo sentido em pares de condutores como o positivo e o negativo ou a fase e o neutro. A corrente de modo comum também flui em feixes de condutores como cabos telefônicos, cabos de informática, cabos do sistema trifásicos, dentre outros. Este distúrbio pode ser causado 
por laços de corrente, por impulsos eletromagnéticos de descargas atmosféricas e sinais interferentes internos ou externos ao sistema em geral

- modo-diferencial - este tipo de ruído se propaga apenas pela linha de fase, fechando o circuito pelo neutro ou pelo plano de terra.

As perturbações induzidas dependem das técnicas de aterramento e de blindagem.

$\mathrm{O}$ aterramento é um fator importante na qualidade da energia. A maioria dos dispositivos eletrônicos utiliza a conexão de terra como referência para todas as outras tensões operacionais e também para a segurança. Além dos danos por falta de aterramento, devem-se considerar que os transientes de energia podem ocorrer de forma bidirecional ao longo da linha de terra. Nem todos os transientes de energia fluem para terra, alguns podem fluir do terra para o equipamento. Técnicas de compatibilidade eletromagnética e de aterramento elétrico são fundamentais para minimizar os efeitos indesejados dos transitórios.

Deve-se procurar evitar o acúmulo de cargas nos componentes condutivos do sistema. Essa aplicação é muito importante no contexto de EMC, pois as descargas eletrostáticas são uma importante fonte de distúrbios, posto que os pulsos resultantes são extremamente rápidos e o sinal induzido depende da taxa $d i / d t$. Esta transferência de cargas poderá resultar em falhas que reduzem a vida útil, prejudicam o funcionamento ou até mesmo destroem o dispositivo. Neste caso, a questão essencial refere-se a assegurar a continuidade das conexões metálicas entre as cargas e os eletrodos de aterramento, pois o valor da impedância de aterramento não é importante para a eliminação de acúmulos de carga.

A implementação de um bom sistema de aterramento na instalação é uma importante linha de defesa contra os distúrbios, assegurando a passagem de correntes indesejadas para o terra e também o correto funcionamento dos dispositivos de proteção. $O$ aterramento e eqüipotencialização implementados com a finalidade de se garantir o bom funcionamento dos circuitos e a compatibilidade eletromagnética são denominados funcionais.

O aterramento com eqüipotencialização visa evitar o aparecimento de diferenças de 
potencial significativas entre partes elétricas da instalação, quando sujeitas a interferências eletromagnéticas. Para atender tal finalidade adota-se, geralmente para o sistema de aterramento, uma composição constituída por vários aterramentos locais interconectados.

O loop de terra é causado pela corrente de modo comum que circula no circuito quando se tem dois ou mais pontos em um sistema elétrico que são aterrados em diferentes pontos. A resistência dos terminais transforma essa corrente em flutuações de tensão, e por causa disso a referência de terra no sistema deixa de ser estável, e o ruído aparece no sinal.

Os efeitos de ruídos podem ser minimizados com técnicas adequadas de projetos, instalação, distribuição de cabos, aterramento e blindagens.

Aterramentos inadequados podem ser fontes de potenciais indesejados e perigosos e que podem comprometer a operação efetiva de um equipamento ou o próprio funcionamento de um sistema. Um bom aterramento também garante a proteção contra sinais de modo-comum.

Já na sua versão de 1997, a norma NBR 5410 demonstrou sua preocupação com este aspecto ao introduzir a seção 6.4.8 "Aterramento e eqüipotencialização de equipamentos de tecnologia da informação", definindo uma proposta de implementação de eqüipotencialização que garanta compatibilidade eletromagnética.

O bom desempenho do aterramento com eqüipotencialização no que se refere ao nível de imunidade a interferências eletromagnéticas tem determinado a superioridade deste conceito nas atuais aplicações no que concerne a EMC. 


\subsection{Estruturas físicas metálicas da edificação}

Pela última versão da norma, o eletrodo de aterramento, também conhecido como malha de aterramento, é considerado uma infra-estrutura, parte integrante das fundações da edificação, e não algo que deva prover apenas à instalação elétrica isoladamente.

Fundamentada nesta idéia, a norma define as armaduras de aço embutidas no concreto das fundações das edificações como o eletrodo de aterramento preferencial numa edificação. Faz-se necessário um entendimento entre arquiteto, engenheiro e construtores da estrutura.

As armaduras de aço das fundações, juntamente com as demais armaduras do concreto da edificação, podem constituir, nas condições prescritas pela NBR 5419, o sistema de proteção contra descargas atmosféricas (aterramento e gaiola de Faraday), completadas por um sistema captor.

A ligação das estruturas metálicas de um prédio é uma boa solução para quem vive em apartamento, em especial nos últimos andares e a distância ao nível do solo é tal que pode comprometer a eficácia dos condutores de proteção.

As características da utilização das fundações de edificações como sistema de aterramento são dadas:

- O eletrodo envolve toda a superfície do prédio, enquanto os eletrodos tradicionais se limitam a algumas hastes localizadas;

- Sendo constituído usualmente por ferro embutido no concreto, o sistema está praticamente protegido contra corrosões, o que pode torná-lo utilizável durante toda a vida do edifício;

- Às edificações de concreto armado existentes podem ser implantadas um SPDA com descidas externas ou, opcionalmente, poderão ser utilizadas como descidas as armaduras de concreto. A multiplicidade de caminhos alternativos para a corrente de descarga diminui o gradiente de tensão uma vez que uniformiza as tensões de flutuação, evitando 
descargas laterais.

Neste último caso, devem ser realizados testes de continuidade e estes devem resultar em resistências medidas inferiores a $1 \Omega$. Deve-se ainda ter muita atenção com o tipo de emenda utilizada nas ferragens estruturais, desde o topo até a base da edificação.

No caso de fundações em alvenaria, o eletrodo de aterramento pode ser constituído por uma fita de aço ou barra de aço de construção, imersa no concreto das fundações, formando um anel em todo o perímetro da estrutura. A fita deve ter, no mínimo, $100 \mathrm{~mm}^{2}$ de seção e $3 \mathrm{~mm} \mathrm{de}$ espessura e deve ser disposta na posição vertical. A barra deve ter o mínimo $95 \mathrm{~mm}^{2}$ de seção. A barra ou a fita deve ser envolvida por uma camada de concreto com espessura mínima de $5 \mathrm{~cm}$.

\subsection{Sistemas de proteção}

Sistema de proteção elétrica é um conjunto de estruturas e dispositivos que devidamente instalados e mantidos visam garantir a segurança das pessoas, evitar danos em equipamentos e materiais e limitar níveis de interferências.

\subsubsection{Seccionamento}

Ação destinada a interromper a alimentação de toda ou de uma determinada parte de uma instalação elétrica, separando-a de qualquer fonte de energia elétrica, por razões de segurança. Há vários dispositivos que atuam como um seccionamento, tais como fusíveis, disjuntores e dispositivos DR. 
O seccionamento automático da alimentação destina-se a evitar que uma tensão de contato se mantenha por um tempo que possa resultar em risco de efeito fisiológico perigoso para as pessoas. [57]

- Fusível: são basicamente constituídos por um condutor de seção reduzida (elo fusível) em relação aos condutores da instalação, montados em uma base de material isolante. Na ocorrência de correntes elevadas, o elo fusível deve fundir-se, interrompendo a passagem de corrente antes que ocorra algum dano à instalação. [37]

- Disjuntor: é um dispositivo de manobra (mecânico) e de proteção, capaz de estabelecer, conduzir e interromper correntes em condições normais do circuito, assim como estabelecer, conduzir por tempo especificado e interromper correntes em condições anormais especificadas do circuito, tais como as de curto-circuito. [4]

- Dispositivo de proteção a corrente diferencial-residual: é um dispositivo (também conhecido como dispositivo DR) de seccionamento mecânico destinado a interromper, num determinado prazo de tempo, a corrente elétrica fornecida a uma carga quando uma corrente que flui para a terra (choque ou fuga de corrente) excede um valor predeterminado. Esta corrente é geralmente muito menor do que a requerida para acionar a proteção de sobrecorrente (fusível ou disjuntor) do circuito de alimentação.

Na disposição de realçar a noção do "seccionamento automático" como composto de eqüipotencialização e dos cuidados necessários à garantia de atuação dos dispositivos de seccionamento, a NBR 5410/2004 discorre sobre as exigências de eqüipotencialização e seccionamento; tais temas receberam uma redação mais direta, valorizando os pontos essenciais.

A NBR 5410/2004 exalta a importância da relação entre a eqüipotencialização e o seccionamento automático da alimentação no item 5.1.2.2.2: "A eqüipotencialização e seccionamento automático da alimentação se completam de forma indissociável, ou seja, quando a eqüipotencialização não é o suficiente para impedir o aparecimento de tensões de contato perigosas, entra em ação o recurso do seccionamento automático, promovendo o desligamento 
do circuito em que se manifesta a tensão de contato perigosa". Tais componentes em conjunto são responsáveis por manter a tensão de contato dentro de valores aceitáveis.

A proteção por seccionamento automático é aquele válido para o esquema TN se as massas ou grupos de massas cuja proteção estiver sendo equacionada forem todas vinculadas a uma mesma eqüipotencialização, e, portanto, a um mesmo eletrodo de aterramento.

\subsubsection{Dispositivo de proteção contra surtos elétricos}

O Brasil é um dos países que mais sofrem com a incidência de descargas elétricas atmosféricas (raios), causando estragos tanto no que tange à perda de vidas humanas quanto em prejuízos de ordem material, entre estes, a queima de equipamentos sensíveis como TVs, computadores, portões automáticos e toda uma gama de equipamentos eletrônicos, cada vez mais presentes no nosso dia a dia.

O sistema de pára-raios predial, quando bem projetado e instalado, é capaz de proteger com sucesso o imóvel e as pessoas que o habitam, porém, não protege os equipamentos sensíveis no seu interior, que podem ser atingidos por sobretensões oriundas da rede elétrica, telefônica ou, ainda, pela TV a cabo. Isso se deve a descarga elétrica que atinge uma rede de transmissão (postes, fios e cabos), a centenas de metros do seu imóvel; esta descarga causa danos aos equipamentos acima descritos. Essas sobretensões são denominadas surtos de tensão (spikes) ou transitórios, que provém do aumento súbito de tensão, gerados pelo retorno da energia após um desligamento geral, ou por descargas atmosféricas (raios).

Para evitar esses danos existem equipamentos específicos (protetores de surto elétrico), que atuam como chaves "super rápidas", que direcionam a descarga elétrica para o aterramento, protegendo os equipamentos sensíveis contra essas sobretensões. 
$\mathrm{Na}$ intenção de se adaptar a grande sensibilidade dos componentes e equipamentos causados por pulsos de tensão, os capítulos que tratam da proteção contra surtos de tensão sofreram significativas alterações na nova edição da NBR 5410, bem como seções subseções correlatas. Some-se a contínua introdução de novas tecnologias construtivas, que otimizam materiais e componentes procurando obter seu máximo desempenho com o menor custo possível. [27]

A necessidade de instalação de proteção contra surtos é referida no capítulo 5.4 na seção 5.4.2.1.1 e é clara a intenção de fornecer especialmente a proteção pessoal. Há uma nota neste referido item que fornece ao projetista a opção de não instalar tal proteção, no entanto, deixando claro que é de total responsabilidade deste profissional tal atitude. Por questão de prudência, é necessário um estudo conclusivo que ateste que não há riscos diretos ou indiretos que possam porventura ocorrer aos usuários daquela instalação.

Os conceitos de aterramento, eqüipotencialização local e de ponto de entrada da edificação são um conjunto de medidas definidas como ferramentas indispensáveis à prevenção de interferências eletromagnéticas, importante fonte de surtos de tensão nas instalações.

Esses conceitos conjuntamente com a instalação dos DPS reduzem os efeitos dos surtos de tensão a níveis aceitáveis para a instalação.

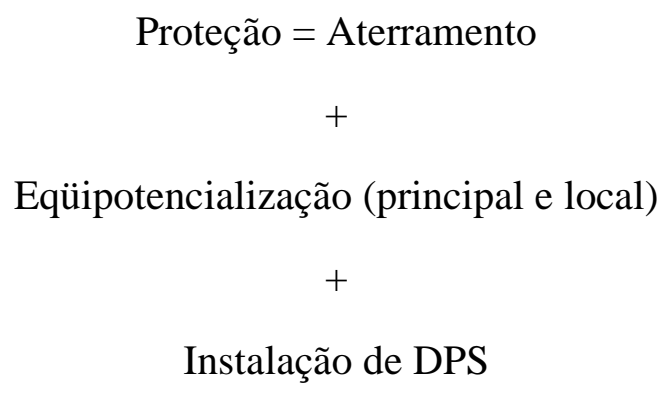

A figura 3.10 representa vários conceitos, com exceção da instalação de DPS, os quais não pertencem diretamente às seções de proteção contra surtos mas que devem ser agregados para que os resultados sejam satisfatórios. 


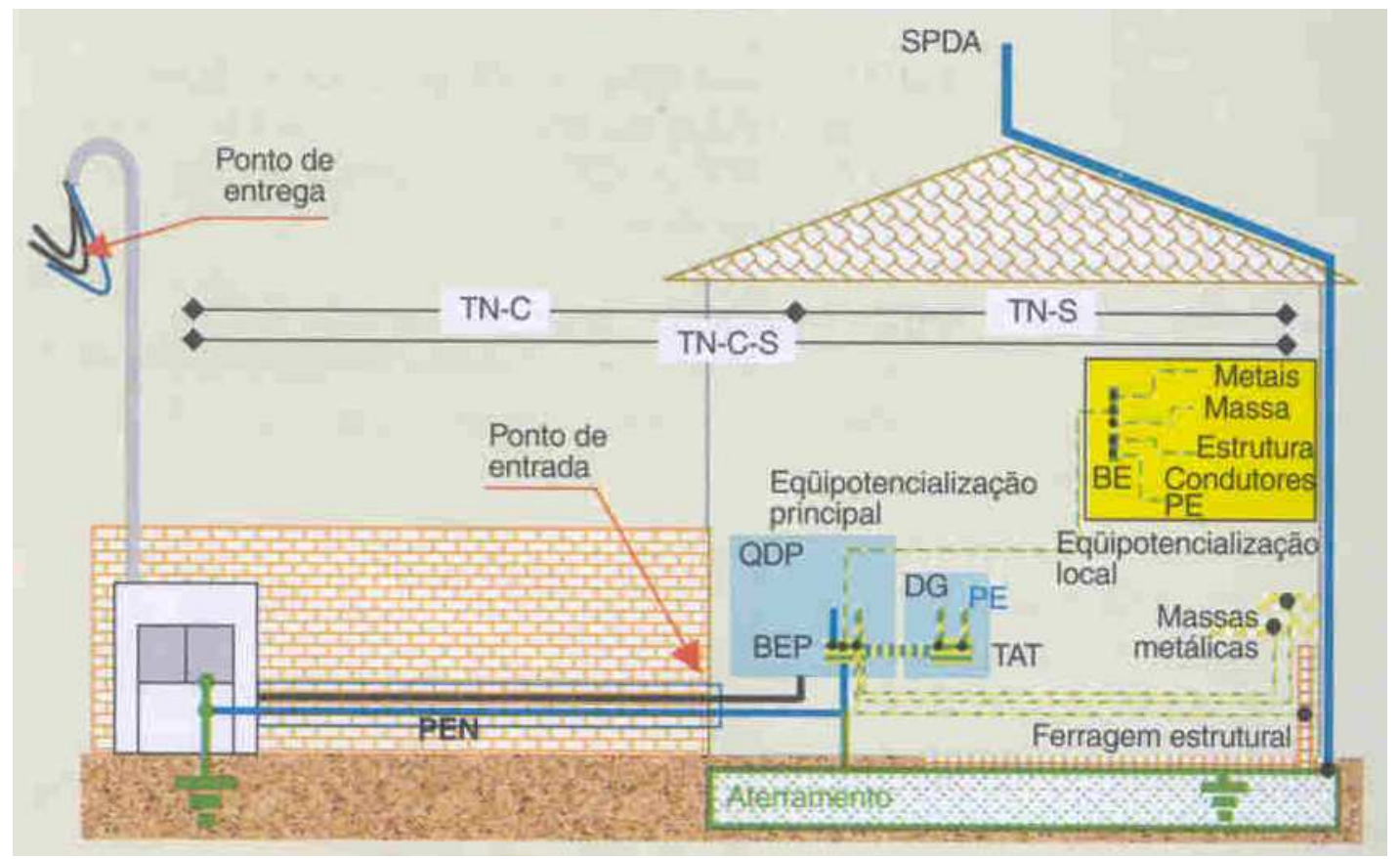

Figura 3.10 - Esquema Referente aos Agregados Necessários ao Resultado Satisfatório dos DPSs em uma Instalação FONTE: Revista EM março de 2005

O esquema de aterramento TN-C-S é o mais apropriado para proteção pessoal. A seção 5.4.3.6 define como obrigatório a separação do condutor PEN (esquema TN-C), normalmente fornecido pelas concessionárias em N (neutro) e PE (esquema TN-S). A exceção se aplica somente para locais onde há somente circuitos que não alimentem ETIs cuja comunicação seja feita através de condutores metálicos externos á edificação. Portanto, considerando-se os parâmetros apresentados é ínfima a quantidade de edificações em que é possível se dispensar a proteção contra surtos.

São dois os critérios a serem seguidos na escolha do DPS:

- proteção contra surtos conduzidos pela linhas elétricas;

- proteção contra surtos induzidos por raios que atingem a edificação ou locais próximos. 


\subsubsection{Seleção e localização dos DPS}

Para ambos os critérios de aplicação acima citados, a condição mínima de proteção a ser considerada é aquela relativa à proteção contra os surtos de modo comum. Dessa forma, para linhas de energia a localização dos DPS deverá sempre estar vinculada ao BEP, fazendo com que esta estrutura atue como referência para que os DPS descarreguem as correntes de surto para o aterramento, minimizando o surto que segue para a instalação.

Os DPS da linha de energia, para casos em que surtos de tensão circulam pelos condutores, podem ser instalados na entrada da instalação ou no quadro de distribuição principal.

No caso em que surtos são provenientes de descargas atmosféricas diretas na edificação ou nas proximidades, o BEP deve atuar como um "aglutinador das diferenças de potencial" que aparecem na instalação e nas massas metálicas da edificação, fazendo com que todos os elementos aterrados no local estejam com a menor diferença possível de potencial entre si. [27]

Dentro desta definição, o propósito é fazer com que as diferenças de potencial que aparecerão entre pontos do aterramento da instalação e da fonte que a alimenta, sejam bem mais elevadas que as geradas por correntes decorrentes de tensões de modo comum no aterramento da edificação.

Ao se selecionar um DPS para proteção de um dado equipamento elétrico, a principal consideração a ser feita é sobre o nível de tensão suportável pelo equipamento e do valor de corrente esperada no ponto onde o DPS estará instalado. Esse último item está diretamente relacionado com:

- o valor máximo da corrente de raio que atinge a edificação ou a linha externa;

- $\quad$ as utilidades que servem a edificação;

- impedância de surto do eletrodo de aterramento. 
No entanto, a correta seleção do DPS depende também da sua instalação apropriada. Um dos problemas do gênero é a avaliação da denominada "distância de proteção", que representa a distância máxima do equipamento, medida ao longo do circuito, em que o DPS ainda é capaz de protegê-lo.

Para descargas diretas na edificação, as sobretensões geradas resultam do acoplamento indutivo da corrente de raio que circula nos elementos condutivos da edificação como os laços condutivos internos, assim como do acoplamento resistivo devido ao aumento do potencial associado à corrente de raio escoando para a terra. As medidas de proteção devem ser dimensionadas de forma a suportar o valor máximo de corrente de raio esperada no ponto de instalação, e localizadas corretamente ao longo do circuito que inclui os equipamentos a serem protegidos. [24]

Os DPS são os mais indicados para assegurar a eqüipotencialização imposta pela proteção contra raios.

A eficácia do DPS na redução do nível de sobretensão não é fácil de avaliar, mas normas internacionais recentes ([10], [11], [12] e [14]) permitem ajudar na seleção, coordenação e instalação destes equipamentos. [24]

O DPS deve ser instalado em localização a depender do conceito de zona de proteção contra raios no limite de cada zona. Na prática, o DPS categoria I (forma de onda de impulso 10/350 $\mu$ s) [13] deve ser instalado no ponto de entrada da linha externa da edificação. [24]

Os DPS das categorias II e III (forma da corrente nominal 8/20 $\mu$ s) devem localizados internamente à instalação e próximos do equipamento sensível, e de qualquer forma à jusante do DPS categoria I. [24] Na figura 3.11, as categorias estão representadas conceitualmente para uma instalação trifásica 127/220V. 


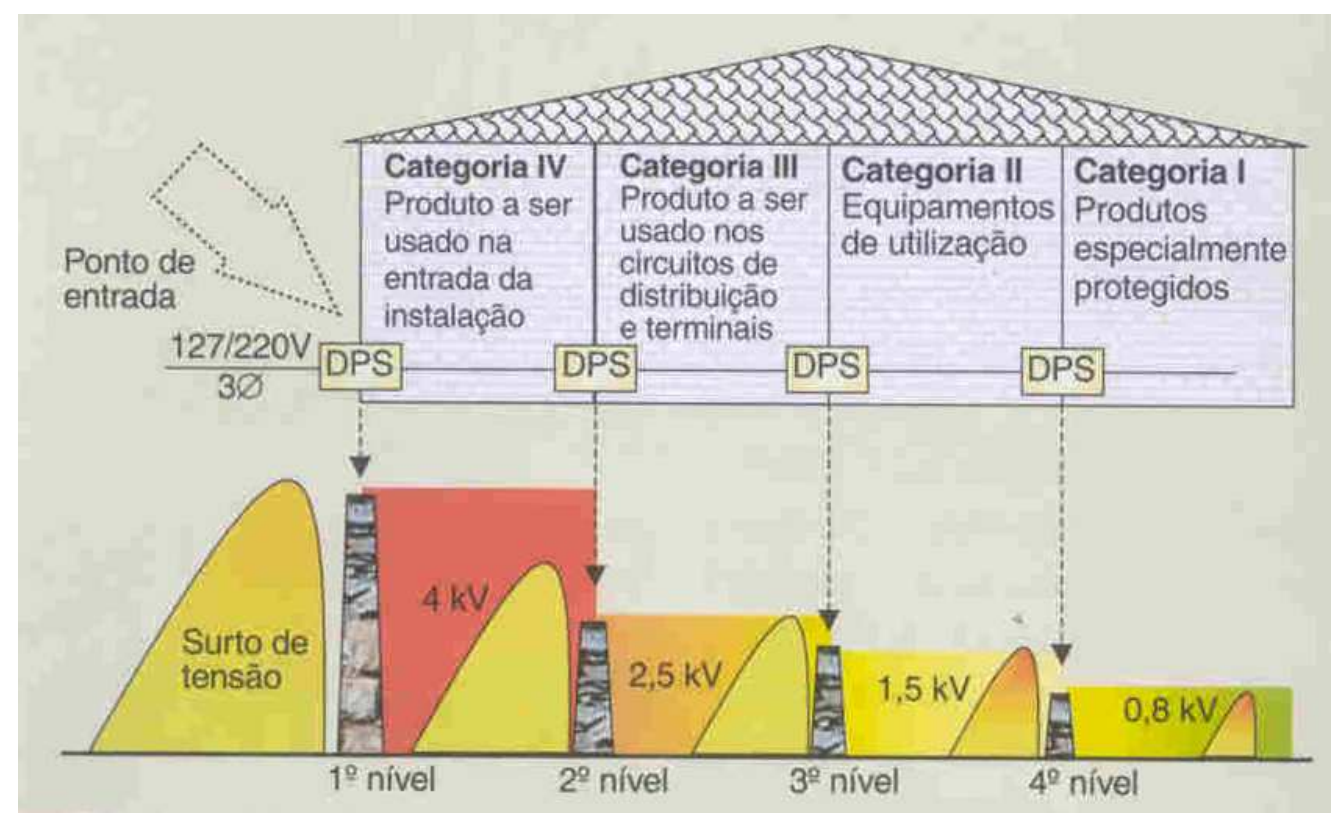

Figura 3.11 - Suportabilidade a Impulsos nas Quatro Categorias Especificadas na NBR 5410 FONTE: Revista EM março de 2005

A avaliação da distância $d$ (distância de proteção) anteriormente citada depende do nível de proteção do DPS a ser utilizado, do seu tipo (centelhador, varistor, etc) e das características dos condutores do circuito principal que alimenta o equipamento.

\subsection{Resistividade do solo}

A resistividade do solo $(\rho)$ é por definição a resistência elétrica $(R)$ medida entre as faces opostas de um cubo de dimensões unitárias preenchido por este solo. Sua unidade é $\Omega$.m. A seguinte equação (5) exprime tal relação:

$$
R=\frac{\rho . l}{A}
$$


Os seguintes fatores determinam a resistividade do solo: tipo de solo, umidade do solo, temperatura, compactação e pressão, concentração e tipos de sais dissolvidos na água retida no solo.

\subsubsection{Características do solo do Distrito Federal}

A resistividade do solo varia acentuadamente com a umidade. Dessa forma, este parâmetro acompanha os períodos de seca e de chuva de uma dada região. Há, no cerrado, duas estações climáticas bem distintas: inverno seco, com elevada deficiência de água (maio setembro) e verão chuvoso, quando ocorre aproximadamente $90 \%$ da precipitação anual (outubro - março). No período seco a condutividade do solo cai consideravelmente pela falta de água.

O Campus da UnB é caracterizado por uma estrutura bastante porosa, denominada "argila porosa”. A seguir é mostrado na figura 3.12, um perfil da estratificação do solo localizado no campo experimental de Fundações e Ensaios de Campo da Universidade de Brasília, localizado próximo ao prédio SG-12 do Campus Universitário, onde fica situado o Programa de Pósgraduação em Geotecnia. 


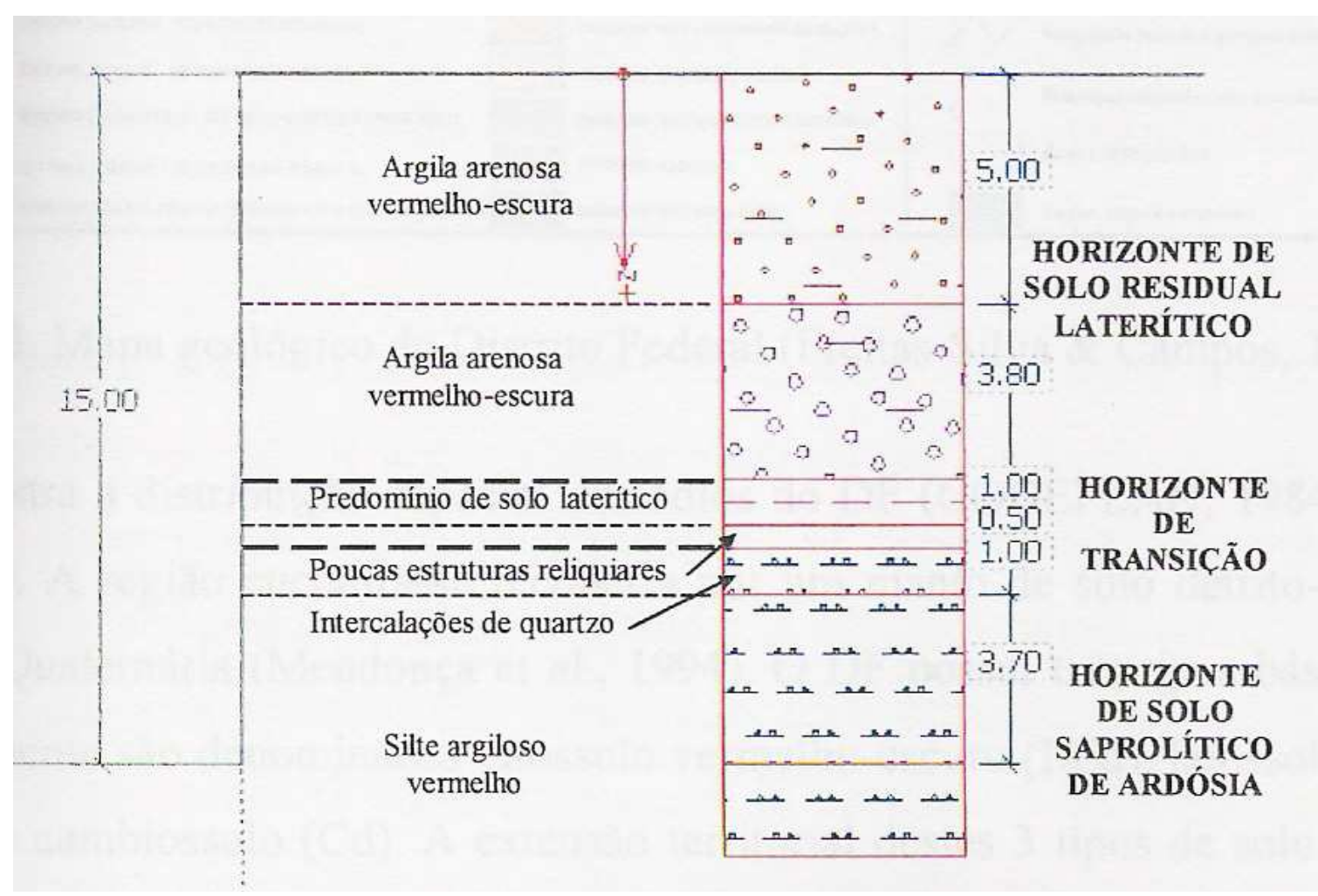

Figura 3.12 - Perfil de Solo do Campo Experimental da UnB

FONTE: Pastore (1996), citado por Dennys Oliveira (2003)

Pela proximidade deste campo experimental com a Faculdade de Tecnologia, considerase que a estratificação destes solos são extremamente semelhantes e, segundo o professor José Elói Guimarães, coordenador do Departamento de Geologia da UnB, a área do Campus Universitário Darcy Ribeiro é constituído basicamente por um mesmo tipo de solo, diferindo consideravelmente somente em alguns pontos específicos, como o Centro Olímpico.

O DF possui três tipos básicos de solo que pedologicamente são denominados latossolo vermelho-escuro, latossolo vermelho-amarelo e cambiossolo. A extensão territorial destes 3 tipos de solo no DF é de 86\% (Cardoso, 1995). 


\subsubsection{Estratificação do solo}

O impacto nas instalações devido à descargas atmosféricas está relacionado a parâmetros desfavoráveis de resistividade do solo. A maioria dos modelos e estudos desenvolvidos para sistemas de aterramento utiliza exemplo de solo uniforme, não considerando o efeito da estratificação. Essa desconsideração ocorre especialmente devido à quantidade de cálculos adicionais que seriam necessários. No entanto, a consideração da estratificação do solo é importante, pois dependendo da resistividade da primeira camada pode-se alcançar valores mais baixos de resistividade em uma segunda camada inferior à primeira, proporcionando uma baixa resistencia e/ou impedância de aterramento.

Essas camadas, devido à formação geológica, são em geral horizontais e paralelas à superfície do solo. Essa variação da resistividade do solo tem como resultado a variação da dispersão de corrente, conforme as figuras 3.13 para o caso da estratificação do solo em duas camadas.
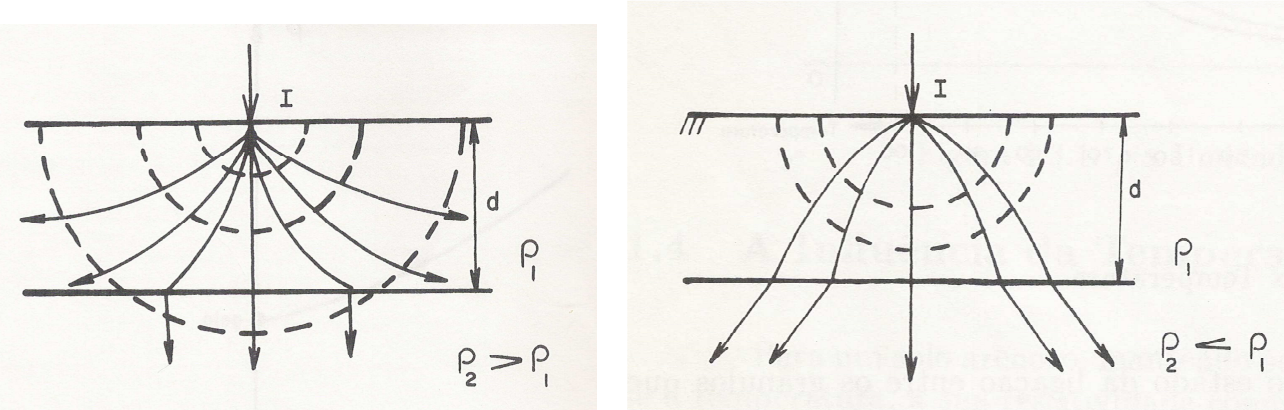

Figura 3.13 - Estratificação do Solo em Duas Camadas

FONTE: Kindermann (1995)

Nas figuras acima, as linhas pontilhadas representam as superfícies equipotenciais, enquanto as linhas cheias representam as correntes elétricas fluindo no solo.

Observa-se ainda pelas figuras que quando se alcança uma camada de estratificação inferior com menor valor de resistividade, o gradiente de potencial ao redor do eletrodo decai mais rapidamente. 


\subsubsection{Técnicas de tratamento do solo}

O tratamento químico do solo tem como objetivo alterar sua constituição química para aumentar sua condutividade.

O tipo mais recomendado de tratamento químico é o uso do Gel químico, que é constituído de uma mistura de diversos sais que, em presença da água, formam o agente ativo do tratamento. Suas propriedades são:

- Quimicamente estável;

- Não solúvel em água;

- Higroscópico;

- Não é corrosivo;

- Não é atacado pelos ácidos contidos no solo;

- Seu efeito é de longa duração.

A tabela 3.1 representa alguns produtos químicos utilizados para o tratamento do solo, e suas respectivas características:

Tabela 3.1 - Comparação entre os Produtos Normalmente Utilizados para Tratamento Químico do Solo FONTE: Luiz César Oliveira (2004)

\begin{tabular}{|c|c|c|c|c|c|c|}
\hline $\begin{array}{c}\text { PRODUTO } \\
\text { QUÍMICO }\end{array}$ & $\begin{array}{c}\text { PROVOCA } \\
\text { CORROSÃO }\end{array}$ & $\begin{array}{c}\text { BAIXO } \\
\text { CUSTO }\end{array}$ & $\begin{array}{c}\text { FÁCIL } \\
\text { APLICAÇÃO }\end{array}$ & LIXIVIÁVEL & POLUENTE & HIGROSCÓPICO \\
\hline SAL & Sim & Sim & Sim & Sim & Não & Não \\
\hline CARVÃO & Não & Não & Não & Não & Não & Não \\
\hline $\begin{array}{c}\text { SAL+ } \\
\text { CARVÃO }\end{array}$ & Sim & Não & Não & Sim & Não & Não \\
\hline $\begin{array}{c}\text { SAL + } \\
\text { CARBONATO }\end{array}$ & Não & Sim & Não & Não & Não & Sim \\
\hline
\end{tabular}




\begin{tabular}{|c|c|c|c|c|c|c|}
\hline DE CÁLCIO & & & & & & \\
\hline BENTONITA & Não & Sim & Não & Não & Não & Sim \\
\hline $\begin{array}{c}\text { EARTHON } \\
\text { (POLPA DE } \\
\text { CELULOSE + } \\
\text { RESINA } \\
\text { VEGETAL) }\end{array}$ & Não & Não & Não & Não & Não & Sim \\
\hline $\begin{array}{c}\text { LABORGEL } \\
\text { (SULFATO } \\
\text { DE COBRE + } \\
\text { SODA } \\
\text { CÁUSTICA + } \\
\text { BENTONITA) }\end{array}$ & Sim & Não & Não & Não & Não & Sim \\
\hline ATERRAGEL & Não & Não & Não & Não & Não & Sim \\
\hline
\end{tabular}

O tratamento do solo é, entretanto, encarado como último recurso, pois sua durabilidade é indeterminada, sendo necessário um controle mais constante das características do solo e de aplicação do tratamento mais de uma vez. Além disso, é importante ter em mente o impacto desses aditivos no ambiente.

Essas técnicas geralmente são adotadas para obtenção dos valores de resistividade recomendados. É possível definir faixas de valores característicos de resistividade para diferentes tipos de solo, nas suas condições usuais de umidade, conforme mostrado na tabela 3.2:

Tabela 3.2 - Valores Típicos de Resistividade de Solo FONTE: Cotrim (2003)

\begin{tabular}{|c|c|}
\hline Natureza do solo & Resistividade $(\boldsymbol{\Omega . m})$ \\
\hline Solos alagadiços/ pantanosos & 5 a 30 \\
\hline Lodo & 20 a 100 \\
\hline Húmus & 10 a 150 \\
\hline Argila plástica & 50 \\
\hline Margas e argilas compactas & 100 a 200 \\
\hline
\end{tabular}




\begin{tabular}{|c|c|}
\hline Areia argilosa & 50 a 500 \\
\hline Areia silicosa & 200 a 3.000 \\
\hline Solo pedregoso nu & 1.500 a 3.000 \\
\hline Solo pedregoso com relva & 300 a 500 \\
\hline Calcáreos moles & 100 a 400 \\
\hline Calcáreos compactos & 1.000 a 5.000 \\
\hline Calcáreos fissurados & 500 a 1.000 \\
\hline Xisto & 50 a 300 \\
\hline Micaxisto & 800 \\
\hline Granito/ arenito & 100 a 10.000 \\
\hline
\end{tabular}

A geometria e as dimensões do aterramento são, no entanto, mais importantes que o valor de resistência de terra. $\mathrm{O}$ valor $10 \mathrm{ohms}$ é recomendado como forma de reduzir os gradientes de potencial no solo.

\subsection{Esquemas de aterramento}

Uma condição importante para a limitação da corrente de falta é o fato desta corrente ter no seu percurso eletrodos de aterramento. Dessa forma, o esquema de aterramento é a classificação que define se a corrente de falta vai passar pelo eletrodo de aterramento. Trata-se de uma classificação de possíveis ligações do condutor neutro e do condutor de proteção nos eletrodos de aterramento, ou seja, combinações possíveis e/ou aplicáveis de interligações entre os 
aterramentos funcional $^{4}$ e de proteção.

O esquema de aterramento é um importante fator na proteção contra choques por contatos indiretos e contra sobretensões, havendo três esquemas de aterramento básicos:

- Esquema TT;

- Esquema TN;

- Esquema IT.

Esses esquemas são classificados em função do aterramento da fonte de alimentação a baixa tensão da instalação e das massas (partes metálicas expostas).

O percurso e a intensidade da corrente de falta será determinado diretamente pelo esquema de aterramento adotado.

$\mathrm{O}$ aterramento funcional consiste na ligação à terra de um dos condutores do sistema, geralmente o neutro, e está relacionado com o funcionamento correto e confiável da instalação.

Aterramento funcional $^{4}$ é o aterramento de um ponto de um sistema, de uma instalação ou de um equipamento, com finalidade distinta da proteção contra choque elétrico. 


\subsubsection{Esquema TT}

Um ponto da alimentação, via de regra o ponto neutro, é diretamente aterrado e as massas da instalação são aterradas individualmente ou em grupos, utilizando eletrodos de aterramento eletricamente independentes do eletrodo da alimentação (figura 3.14).

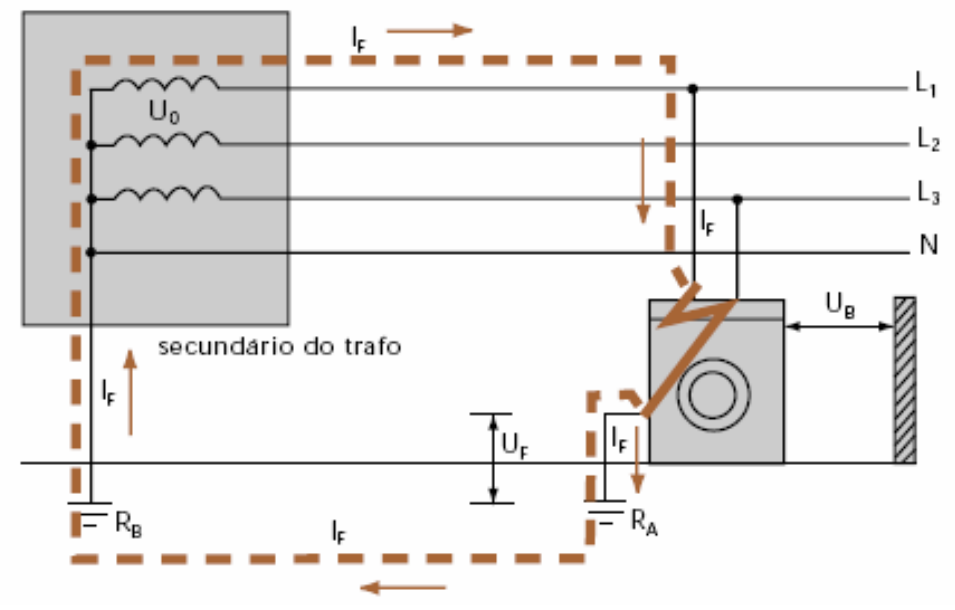

Figura 3.14 - Esquema TT

FONTE: http://www.procobre.org/pr/pdf/pdf_pr/03_aterrame.pdf

O percurso de uma corrente de falta massa-terra num componente ou equipamento inclui a terra determinando uma alta impedância no percurso capaz de limitar a corrente de falta, sendo inferiores a uma corrente de curto-circuito, mas suficiente para representar perigo às pessoas.

\subsubsection{Esquema $T N$}

Um ponto da alimentação, via de regra o ponto neutro, é diretamente aterrado e as massas da instalação são ligadas a esse ponto através de condutores de proteção (figura 3.15). 


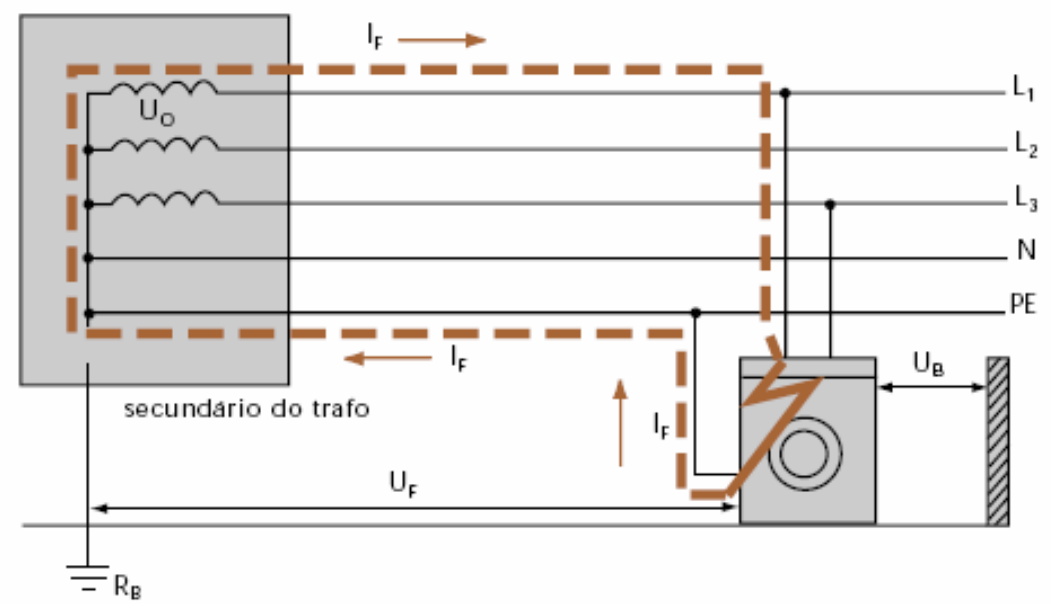

Figura 3.15 - Esquema TN

FONTE: http://www.procobre.org/pr/pdf/pdf_pr/03_aterrame.pdf

Neste esquema o percurso da corrente de falta possui baixa impedância. Toda corrente de falta direta fase-massa é uma corrente de curto-circuito (fase-neutro) sendo portanto, permitido que a detecção dos defeitos sejam efetuados por dispositivos de proteção contra sobrecorrentes instalados em todos os condutores de fase.

$\mathrm{O}$ esquema TN é mais recomendado em instalações alimentadas por trafo ou gerador próprio.

O esquema TN ainda pode ser subdividido em:

- Esquema TN-S;

- Esquema TN-C;

- Esquema TN-C-S. 


\subsubsection{Esquema TN-S}

No esquema TN-S a corrente de neutro circula somente pelo condutor neutro (figura 3.16).

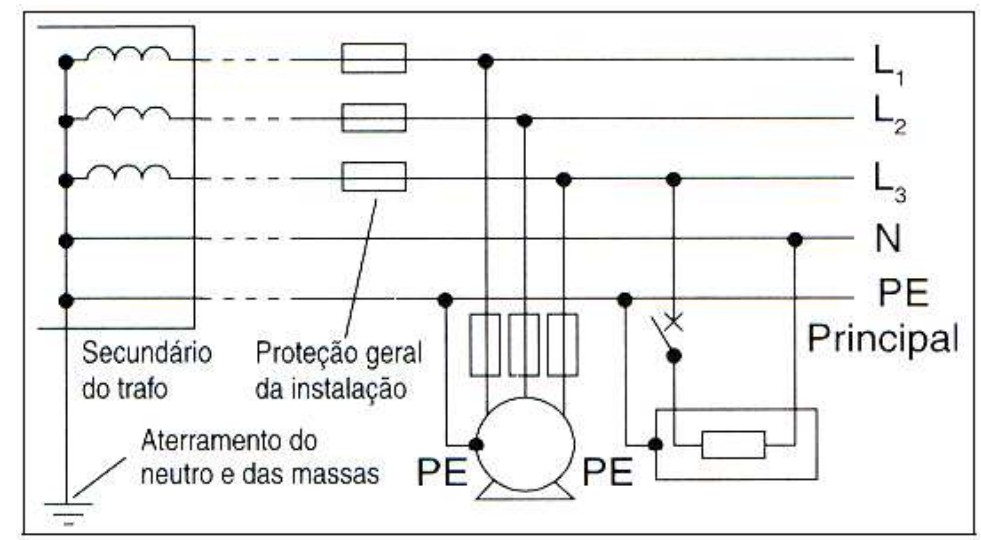

Figura 3.16 - Esquema TN-S

FONTE: Cotrim (2003)

\subsubsection{Esquema $T N-C$}

No esquema TN-C um desequilíbrio de cargas no sistema trifásico gera circulação de corrente no neutro, que por sua será dividida entre o condutor PEN, as blindagens e os elementos condutores (figura 3.17). 


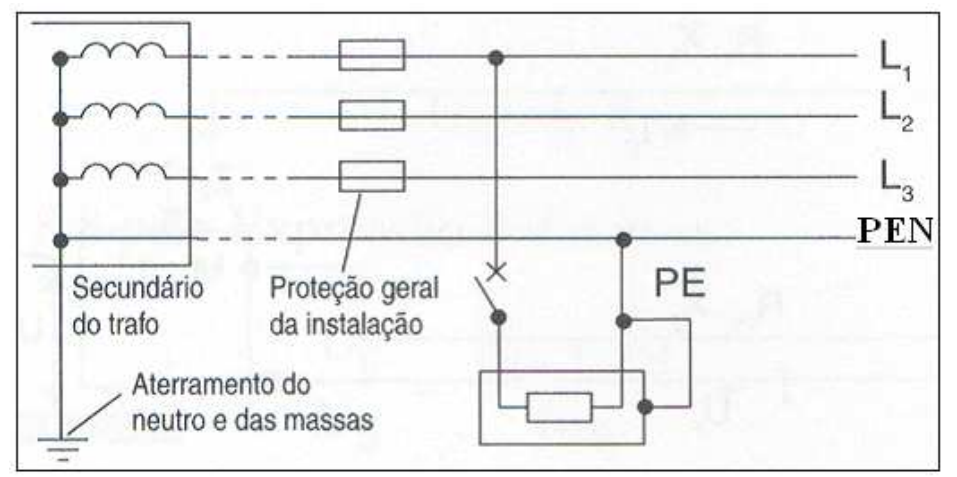

Figura 3.17 - Esquema TN-C

FONTE: Cotrim (2003)

\subsubsection{Esquema $\mathrm{TN}-\mathrm{C}-\mathrm{S}$}

O TN-C-S combina uma rede pública do tipo TN-C e uma instalação do tipo TN-S, ou seja, as funções de neutro e de condutor de proteção são combinadas num único condutor em uma parte da instalação (figura 3.18).

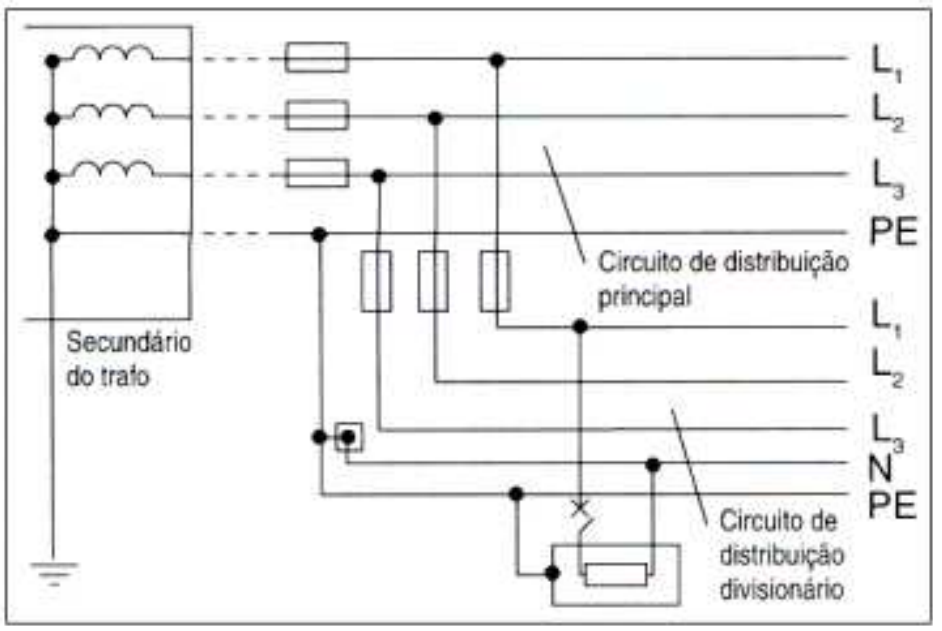

Figura 3.18 - Esquema TN-C-S

FONTE: Cotrim (2003) 


\subsubsection{Esquema IT}

A característica deste esquema é a não-existência de aterramento direto de qualquer ponto da alimentação e, as massas são aterradas em um mais eletrodos de aterramento independentes em geral do eletrodo de aterramento existente para a alimentação (figura 3.19).

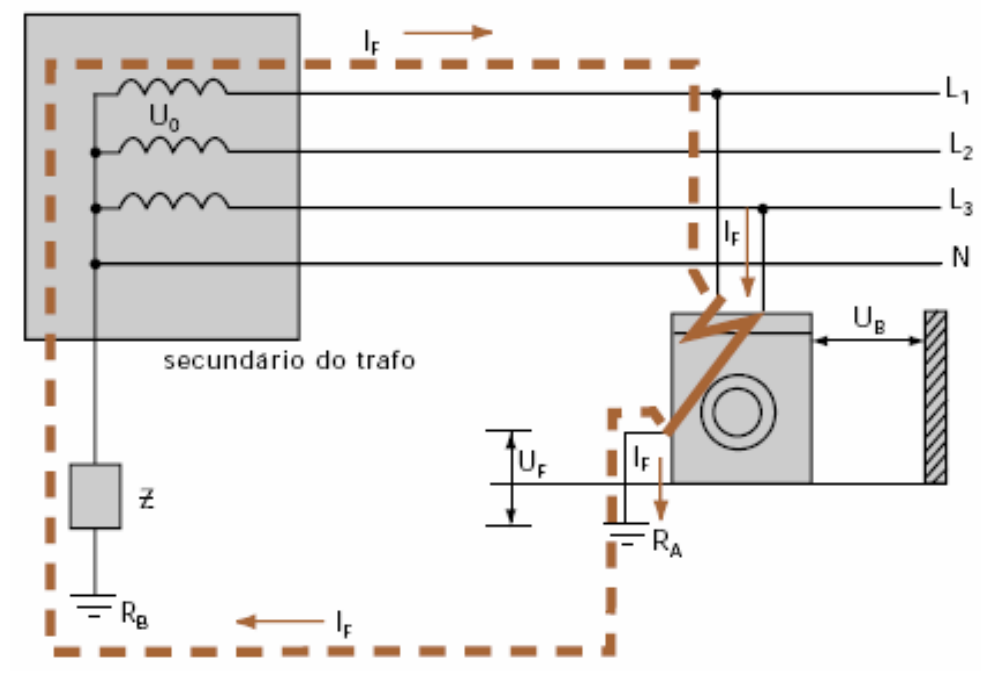

Figura 3.19 - Esquema IT

FONTE: http://www.procobre.org/pr/pdf/pdf_pr/03_aterrame.pdf

O esquema IT é recomendado para hospitais e industrias porque não permite que o sistema seja desligado imediatamente quando da ocorrência de uma primeira falta porque há limitação da corrente resultante. A corrente não deve ter intensidade suficiente para provocar o surgimento de tensões de contato perigosas.

Nas instalações alimentadas por rede pública em baixa tensão, devido à exigência de aterramento do neutro na origem da instalação, só podem ser usados os esquemas TN e TT. No entanto, como nessa rede o condutor neutro de cada ramal de alimentação é aterrado na origem da respectiva instalação consumidora, só poderão ser utilizados os esquemas TT ou TN-C-S.

Importante observar que, nos esquemas que determinam impedância de percurso suficientemente baixa, é garantida a proteção por dispositivos de proteção contra sobrecorrentes. 


\subsection{Leis e normas referentes à segurança das instalações}

Alguns itens sobre segurança das instalações elétricas, no que concerne principalmente à garantia de segurança dos seres vivos, são cada vez mais referidos em normas específicas, adquirindo inclusive caráter de obrigatoriedade sob a forma de Lei.

É importante observar que esse aumento da quantidade das normas, sua especificidade, assim como o caráter obrigatório de muitos itens reflete a preocupação em se criar uma padronização que incorre necessariamente em qualidade e segurança aos produtos e sistemas elétricos.

A Lei 11337 de 26 de julho de 2006 em sua ementa determina a obrigatoriedade da existência de aterramento nas edificações, e de instalações elétricas compatíveis com a utilização de condutor terra de proteção, bem como torna obrigatória a existência de condutor terra de proteção nos equipamentos que ela especifica.

As principais normas nacionais sobre instalações elétricas a baixa tensão são a NBR 5410 e a NBR 5419. As outras normas são mais específicas e vêm no sentido de garantir que determinadas prescrições sejam atendidas. Tal caráter pode ser observado no fato de que a condução do condutor terra de proteção para as tomadas fixas, conforme exigência da NBR 5410 será garantida através da adoção de um padrão brasileiro de tomadas e plugues (NBR 14136), nas quais as mesmas vêm com contato de aterramento. A preocupação se deve ao fato de que a tomada fixa é a interface entre os aparelhos eletroeletrônicos e a instalação elétrica.

A última versão da NR-10 apresenta as mesmas preocupações em garantir a segurança dos trabalhadores que interajam em instalações elétricas, que norteiam tanto a referida padronização NBR 14136 quanto a NBR 5410.

Como toda transição do gênero, a disseminação do padrão para as tomadas e plugues será gradual e sua obrigatoriedade só se aplica para as novas instalações. 


\section{Capítulo 4}

\section{Instalações Elétricas da Faculdade de Tecnologia}

Neste capítulo serão explanados os tópicos relacionados às condições atuais das instalações elétricas da FT, apresentando-se os dados de campo no que se refere à alimentação, aterramento, eqüipotencialização e características das cargas presentes nas instalações.

Para situar posição relativa entre transformadores e centros de cargas, no íntimo anexo há uma planta baixa com definição dos blocos que formam a Faculdade de Tecnologia.

\subsection{Sistema de alimentação principal}

A Faculdade de Tecnologia possui uma Subestação $13.8 \mathrm{kV} / 380 \mathrm{~V}$ de $500 \mathrm{kVA}$ a qual alimenta maior parte das cargas deste prédio (Departamentos da Engenharia Elétrica, Engenharia Civil, Engenharia Mecânica, Engenharia Florestal, Engenharia Mecatrônica e Bloco D). A parcela restante é alimentada diretamente à baixa tensão através de dois transformadores; um dos transformadores, de $75 \mathrm{kVA}$ (foto 4.1), alimenta o CDT (Centro de Apoio ao Desenvolvimento Tecnológico), o Laboratório de Redes e o NMI (Núcleo de Multimídia e Internet), enquanto o outro transformador, de $150 \mathrm{kVA}$ (foto 4.2), alimenta unicamente o GRACO (Grupo de 
Automação e Controle). Há ainda a situação de que algumas cargas dos ambientes alimentados diretamente pelos dois transformadores são alimentadas também por ramais da Subestação e vice-versa.

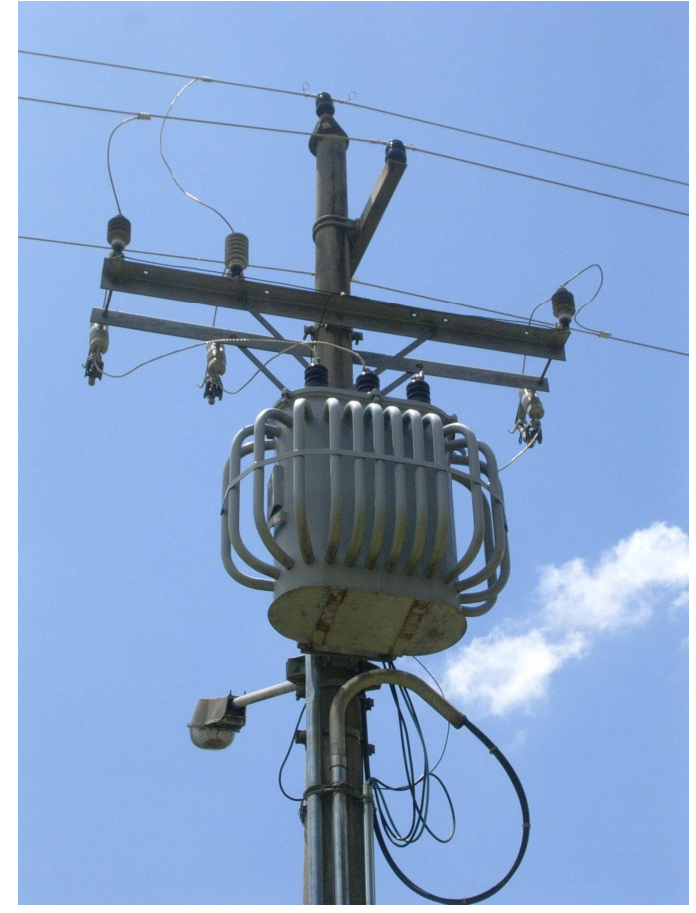

Foto 4.1 - Trafo de $75 \mathrm{kVA}$

FONTE: Pesquisa de Campo

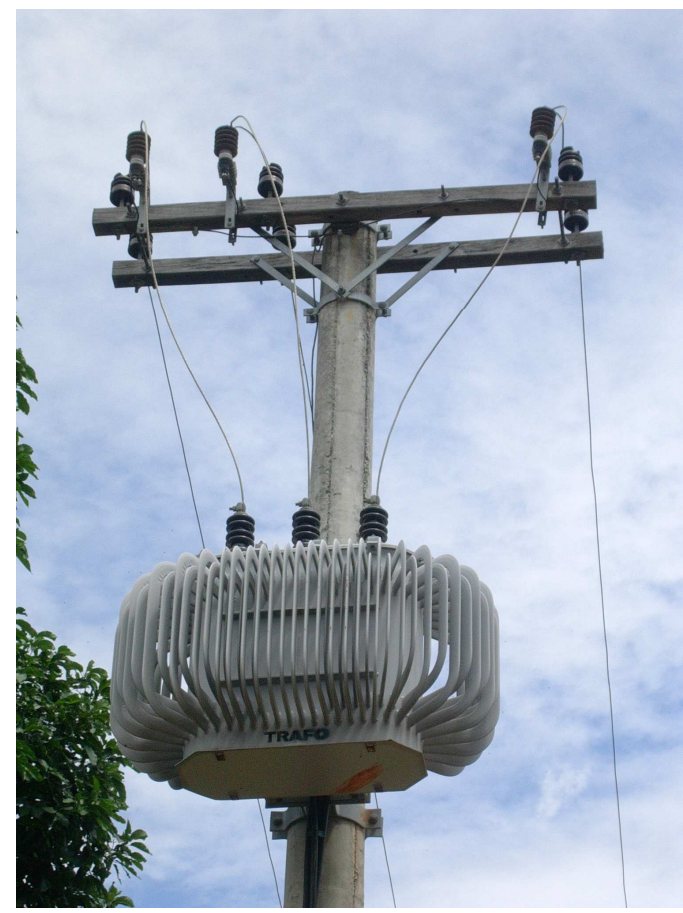

Foto 4.2 - Trafo de $150 \mathrm{kVA}$

FONTE: Pesquisa de Campo

O QGBT (Quadro Geral de Baixa Tensão) possui um único barramento desempenhando ambas as funções de terra e neutro (esquema TN-C). O atual padrão CEB (Companhia Energética de Brasília), no entanto, determina a presença de um barramento para terra jumpeado com um barramento para neutro. A necessidade de presença destes dois barramentos individuais se deve a um critério para diferenciação dos cabos de terra (cor verde) e neutro (cor azul) dentro da instalação.

O barramento terra deste quadro (foto 4.3) possui atualmente a função de BEP dentro da instalação e sem a existência de um dispositivo protetor contra surtos. 


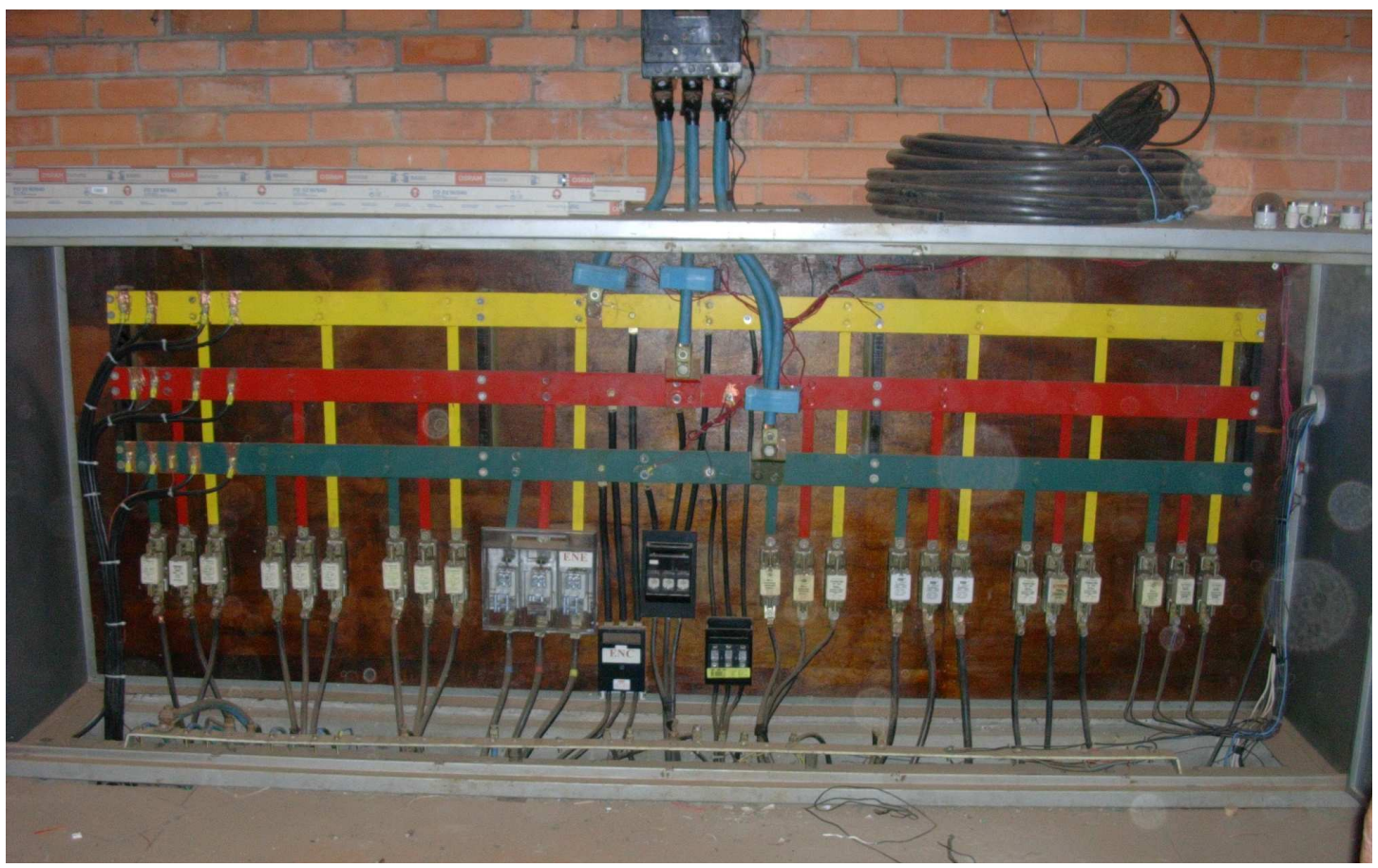

Foto 4.3 - QGBT - Subestação

FONTE: Pesquisa de Campo

\subsection{Quadros de distribuição}

Nos Departamentos das Engenharias Elétrica, Civil, Mecânica, Bloco D, Mecatrônica e Florestal há, para cada departamento, um quadro de distribuição proveniente do QGBT (fotos 4.4, 4.5, 4.6, 4.7, 4.8 e 4.9 respectivamente e planta-baixa no anexo B.

Os transformadores existentes foram instalados posteriormente à concepção da Faculdade de Tecnologia em decorrência do aumento da demanda e da formação de novos laboratórios.

O Laboratório de Redes, cujos computadores são contemplados com energia condicionada por um equipamento nobreak, recebe alimentação direta do transformador de 75 
kVA. Seu quadro de distribuição está mostrado na foto 4.10. Deste mesmo transformador é fornecida alimentação para os quadros de distribuição do NMI (foto 4.11) e do CDT (foto 4.12).

O GRACO, por ser um laboratório que comporta equipamentos de grande porte e sofisticação, foi atendido com alimentação exclusiva, cujo único quadro de distribuição está mostrado na foto 4.13 .

O diagrama unifilar das instalações elétricas da Faculdade de Tecnologia está representado na figura 4.1 (vide planta-baixa no anexo B).
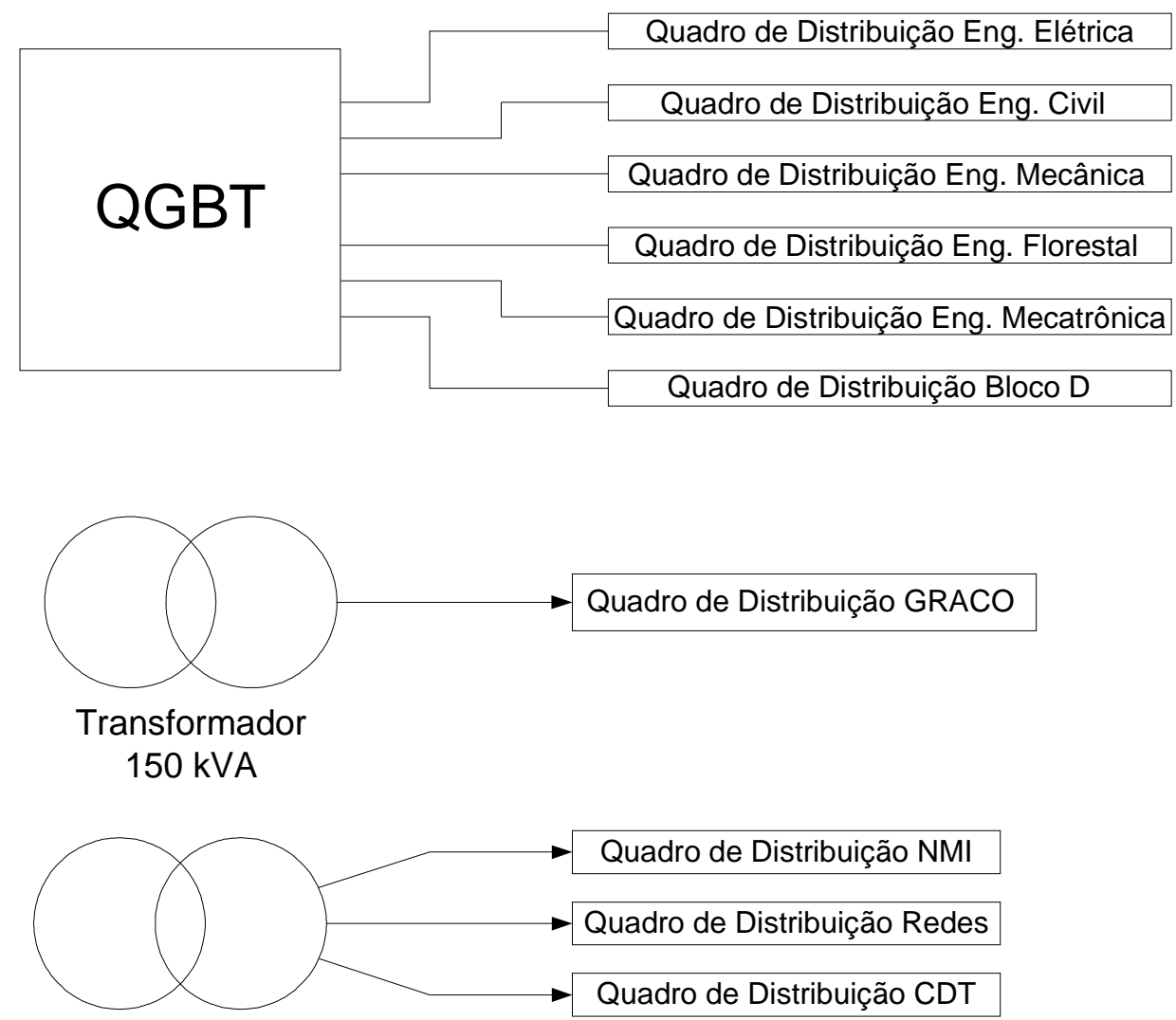

Transformador

75 kVA

Figura 4.1 - Diagrama Unifilar

FONTE: Pesquisadoras do Projeto 


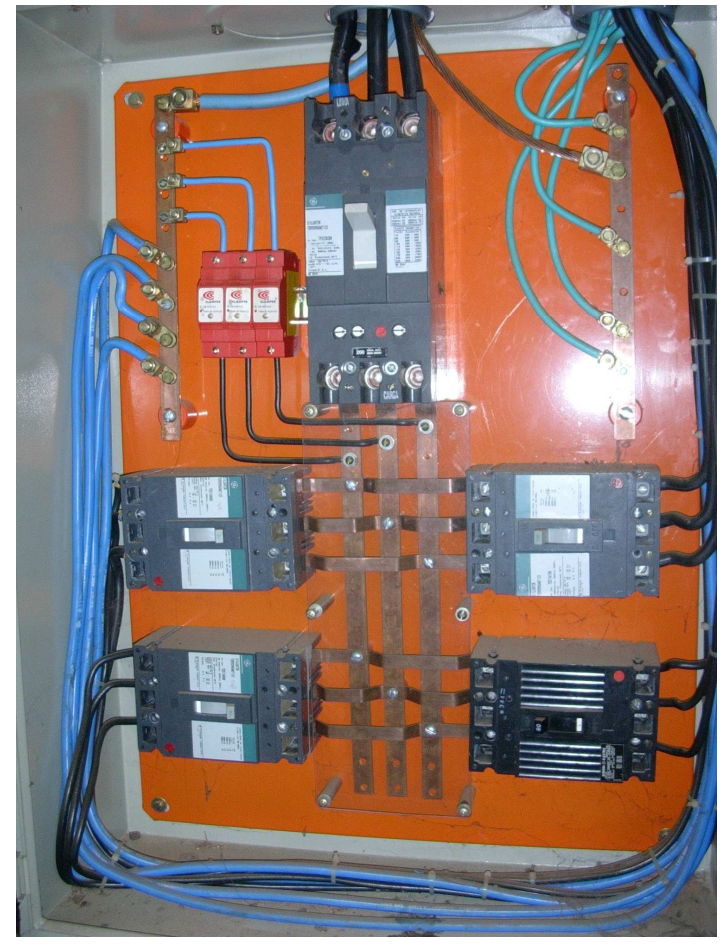

Foto 4.4 - Quadro de Distribuição da Eng. Elétrica FONTE: Pesquisa de Campo

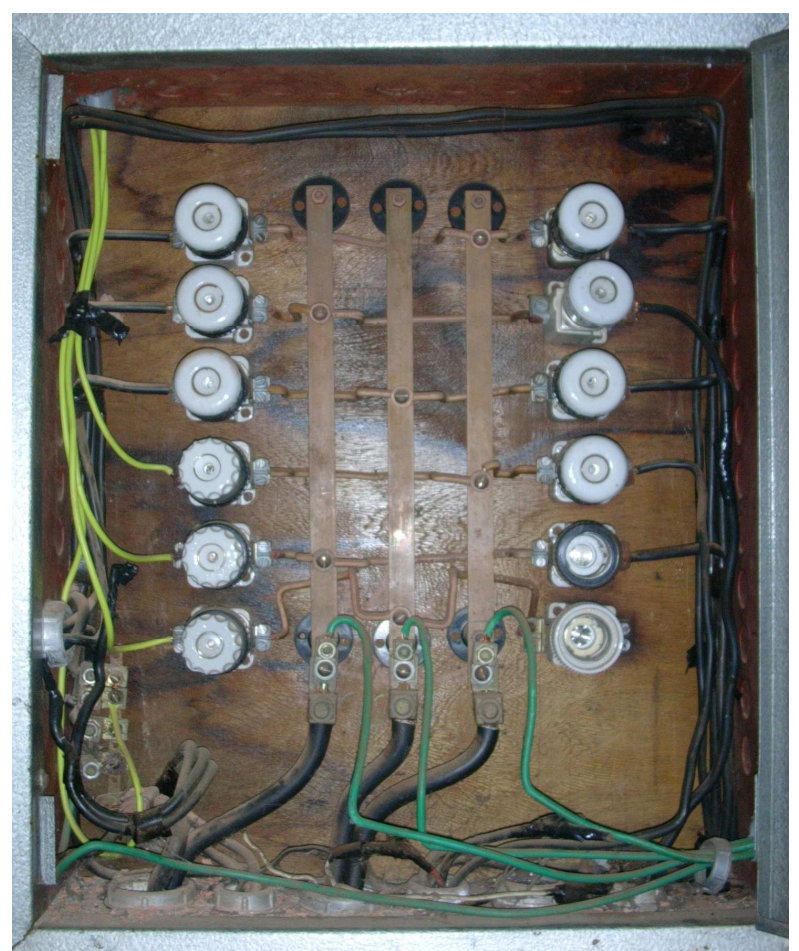

Foto 4.5 - Quadro de Distribuição da Eng. Civil FONTE: Pesquisa de Campo 


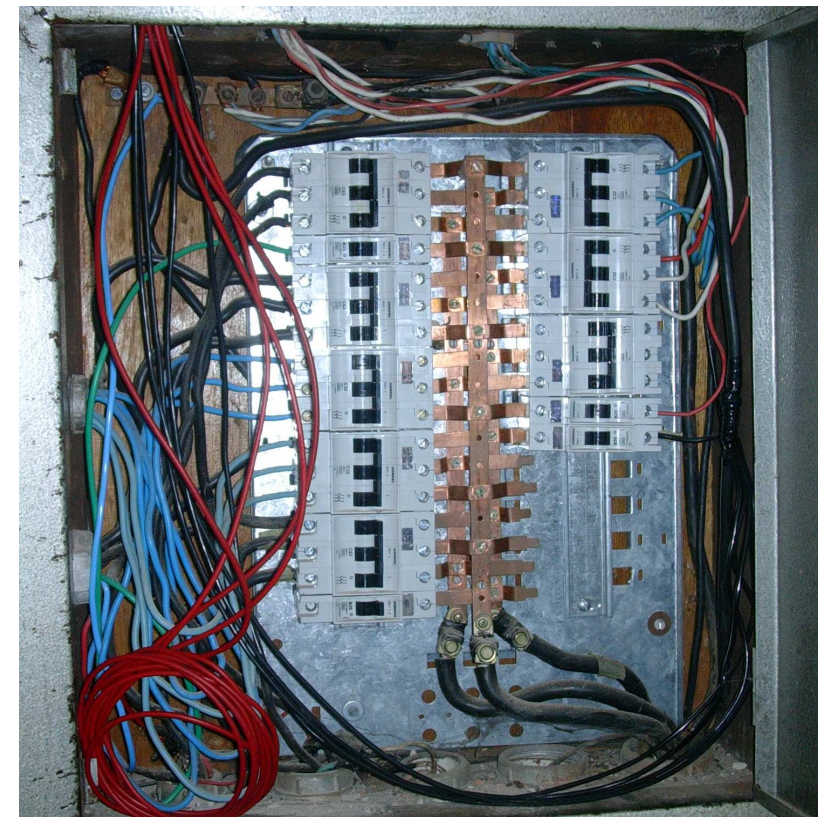

Foto 4.6 - Quadro de Distribuição da Eng. Mecânica FONTE: Pesquisa de Campo

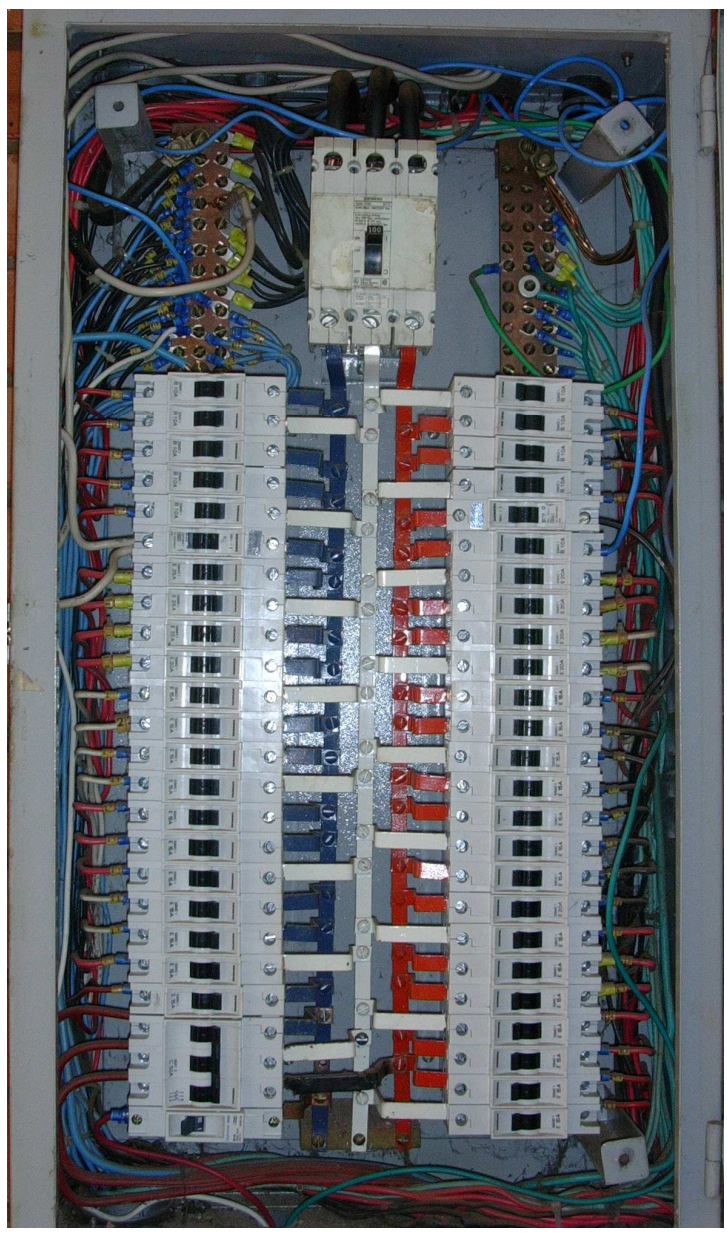

Foto 4.7 - Quadro de Distribuição do Bloco D FONTE: Pesquisa de Campo 


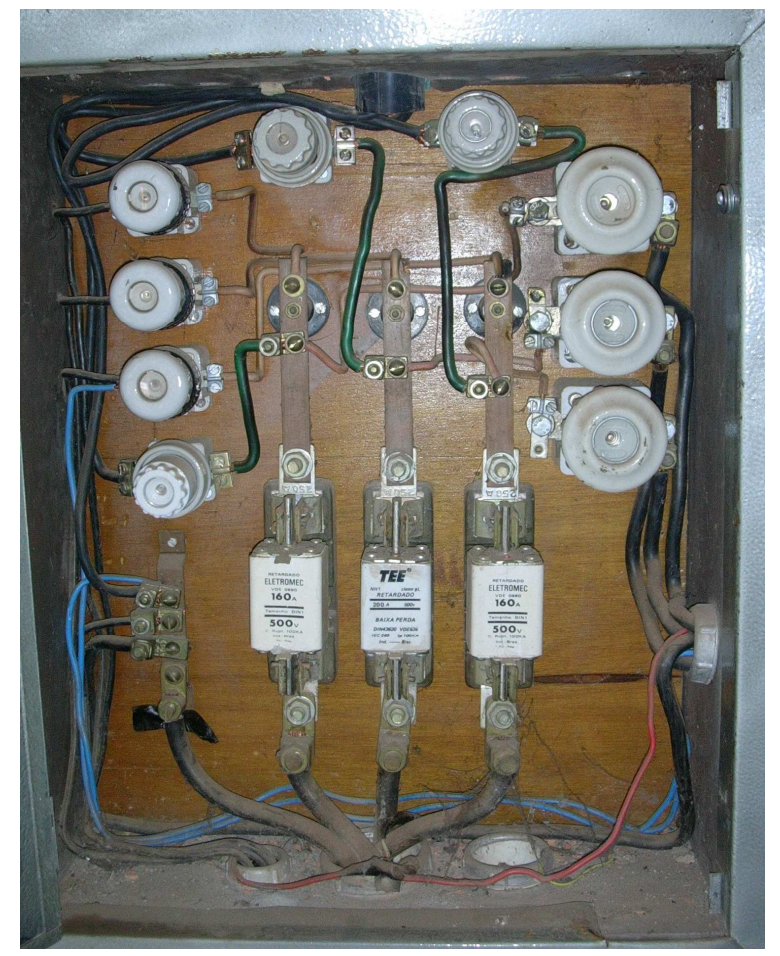

Foto 4.8 - Quadro de Distribuição da Eng. Mecatrônica FONTE: Pesquisa de Campo

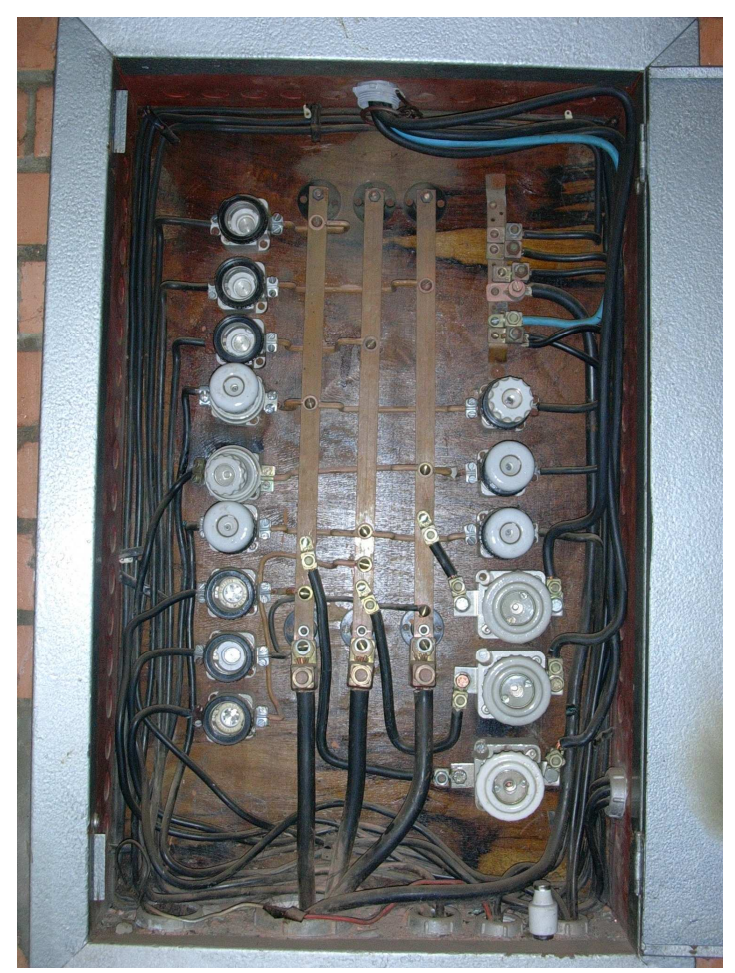

Foto 4.9 - Quadro de Distribuição da Eng Florestal FONTE: Pesquisa de Campo 


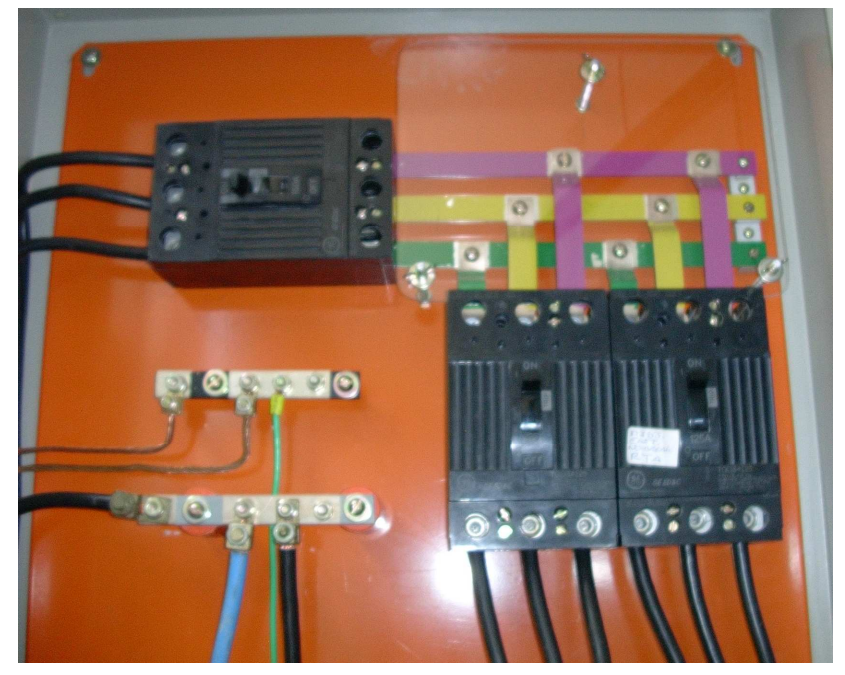

Foto 4.10 - Quadro de Distribuição da Eng. Redes FONTE: Pesquisa de Campo

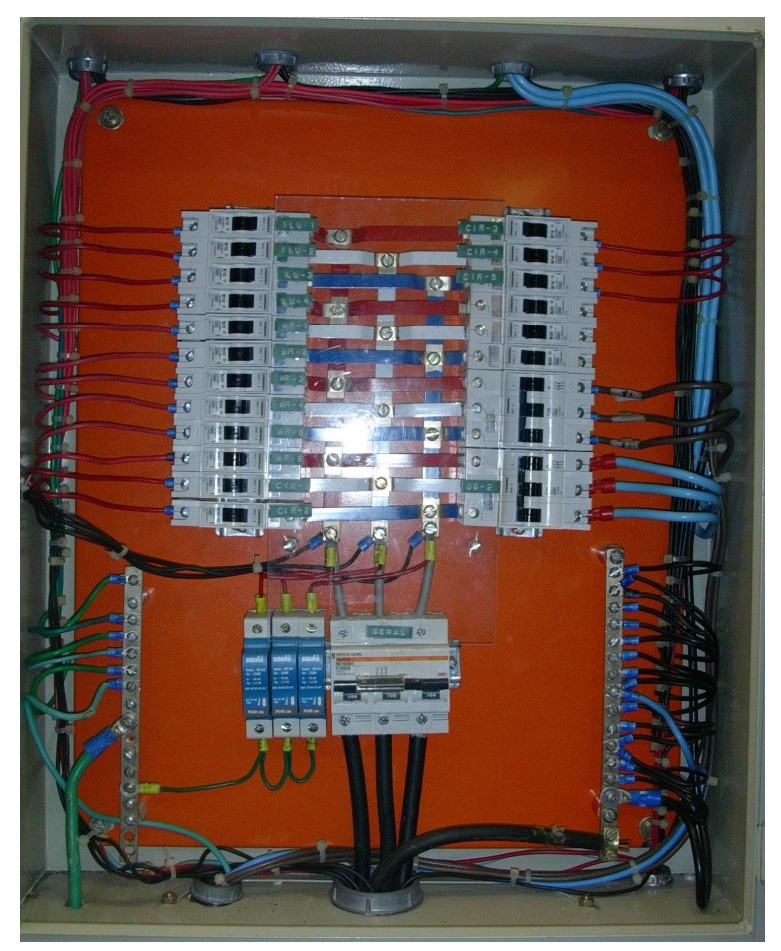

Foto 4.11 Quadro de Distribuição do NMI FONTE: Pesquisa de Campo 


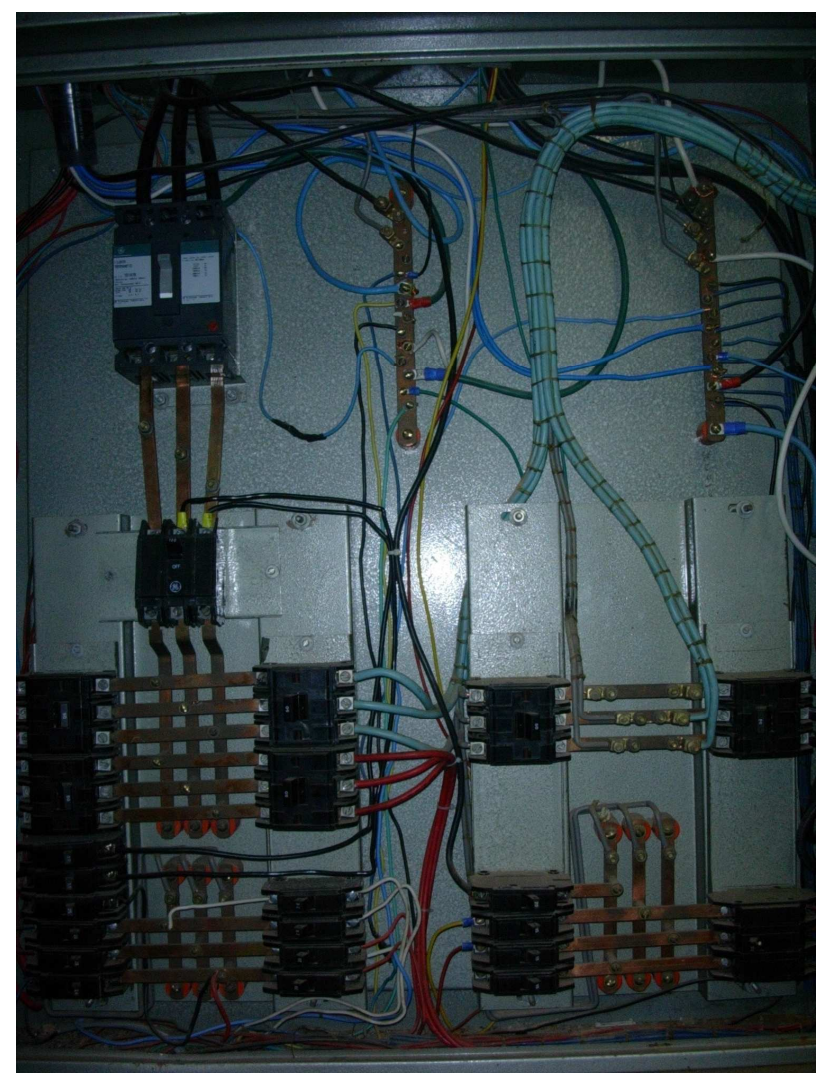

Foto 4.12 - Quadro de Distribuição do CDT FONTE: Pesquisa de Campo

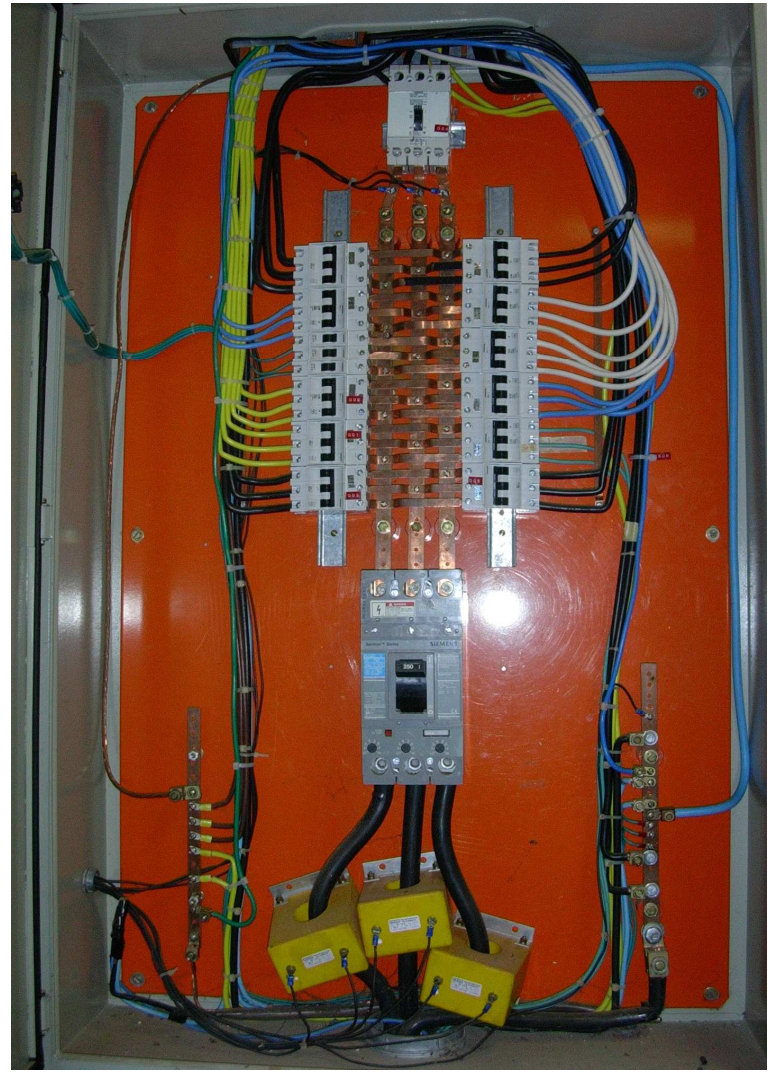

Foto 4.13- Quadro de Distribuição do GRACO FONTE: Pesquisa de Campo

Á jusante do QGBT todos os quadros deveriam ser providos de cabos de terra e neutro individuais (esquema TN-S), no entanto, isso não fora observado em todos eles, conforme dados da tabela 4.1. Em contrapartida, na maioria dos quadros há um único barramento desempenhando ambas as funções.

Conforme descrito nesta mesma tabela, apenas no quadro de distribuição da Engenharia Elétrica e do NMI há instalado protetor contra surtos. 
Tabela 4.1- Características dos Quadros de Distribuição

FONTE: Pesquisa de Campo

\begin{tabular}{|c|c|c|}
\hline Quadro de Distribuição & $\begin{array}{c}\text { Protetor contra } \\
\text { surtos }\end{array}$ & $\begin{array}{c}\text { Barramento terra e neutro } \\
\text { individuais }\end{array}$ \\
\hline Departamento de Eng.Elétrica & Presente & SIM \\
\hline Departamento de Eng. Civil & Ausente \\
\hline Departamento de Eng. Mecânica & Ausente & NÃO \\
\hline Bloco D & Ausente & SIM \\
\hline Departamento de Eng. Redes & Ausente & SIM \\
\hline NMI & Presente & NÃO \\
\hline Departamento de Eng. Florestal & Ausente & SIM \\
\hline GRACO & Ausente & SIM \\
\hline CDT & Ausente & NÃO \\
\hline Departamento de Eng. Mecatrônica & Ausente & \\
\hline
\end{tabular}

Conforme mostrado na tabela 4.1, há vários quadros com barramentos terra e neutro unificados. Esta situação, dentro da instalação em questão, pode ser um problema dada a inexistência de um controle sobre o balanceamento das cargas entre as fases. Tal desbalanceamento gera circulação indesejada de corrente pelo cabo de neutro, que em uma instalação cujo esquema é o TN-C, poderá incorrer em circulação de parcela da corrente de neutro pelo condutor de proteção.

Além disso, em edificações que abrigam ou estejam previstas para abrigar instalações de tecnologia da informação de porte significativo, deve-se considerar o uso de condutor de proteção $(\mathrm{PE})$ e condutor neutro $(\mathrm{N})$ separados desde o ponto de entrada da alimentação. Esta prescrição tem por objetivo reduzir a possibilidade de ocorrência de problemas de 
compatibilidade eletromagnética e, em casos de sobrecorrente, a passagem de correntes de neutro nos cabos de transmissão de sinais.

Como a instalação elétrica da edificação possui transformadores responsáveis pela alimentação de equipamentos de tecnologia da informação e essas fontes são, elas próprias, alimentadas em esquema TN-C, deve-se adotar o esquema TN-S em sua saída.

A existência de barramentos terra e neutro é tecnicamente imprescindível para instalação de DPS.

A carga do prédio é composta em sua boa parte por computadores, que são equipamentos sensíveis. Há laboratórios de informática onde são processadas e armazenadas informações de alto grau de importância para seus usuários e, portanto, para a faculdade. Estas cargas convivem na mesma rede com aparelhos ar-condicionado do tipo janela e do tipo Split que, por sua vez, apresentam comportamento normal de consumo em forma de surtos. A convivência dessas cargas de diferentes naturezas em quadros comuns somada a uma instalação sem protetores contra surtos permite que os surtos gerados pelos equipamentos de ar-condicionado afetem diretamente os computadores.

\subsection{Sistema de aterramento da Faculdade de Tecnologia}

Em todo o prédio observou-se que os usuários dos equipamentos improvisaram o aterramento dos mesmos conectando o seu cabo terra diretamente ao solo, gerando "terras virtuais" como mostrado na foto 4.14. Tal situação está aplicada especialmente à computadores, aparelhos de ar-condicionado e alguns pequenos quadros terminais.

Dessa forma, o barramento terra dos quadros que alimentam essas cargas está sem funcionalidade e estes equipamentos não estão protegidos. A presença de grande quantidade de cabos terra conduzidos ao solo traduz a mentalidade das pessoas em crer na eficiência de terras 
"egoísticos". Numa análise mais técnica, tais situações demonstram a ignorância das pessoas em relação aos conceitos de aterramento e eqüipotencialização.

O cabo terra para os circuitos deve ser provido diretamente pelo barramento terra do quadro que o alimenta.

No entanto, mesmo na situação em que o cabo terra é provido diretamente pelo seu respectivo quadro, a eficiência do condutor de proteção só estará garantida na existência de um correto e bom sistema de aterramento e eqüipotencialização servindo estes quadros e todo o sistema.
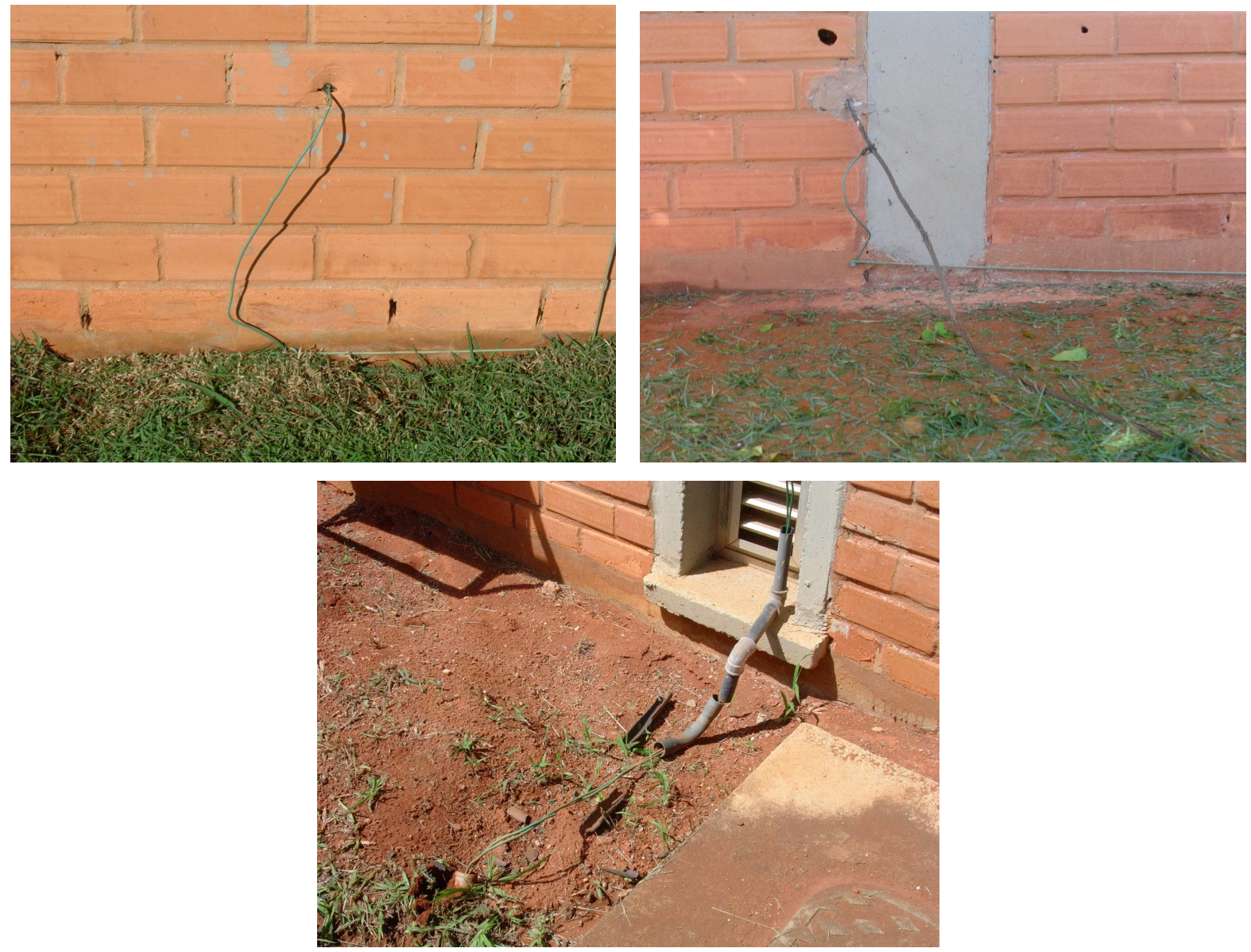

Foto 4.14 - "Terras Virtuais"

FONTE: Pesquisa de Campo 
Importante observar, conforme ilustrado na foto 4.15, que mesmo estes terras improvisados são feitos precariamente, com ausência de contato com o solo.
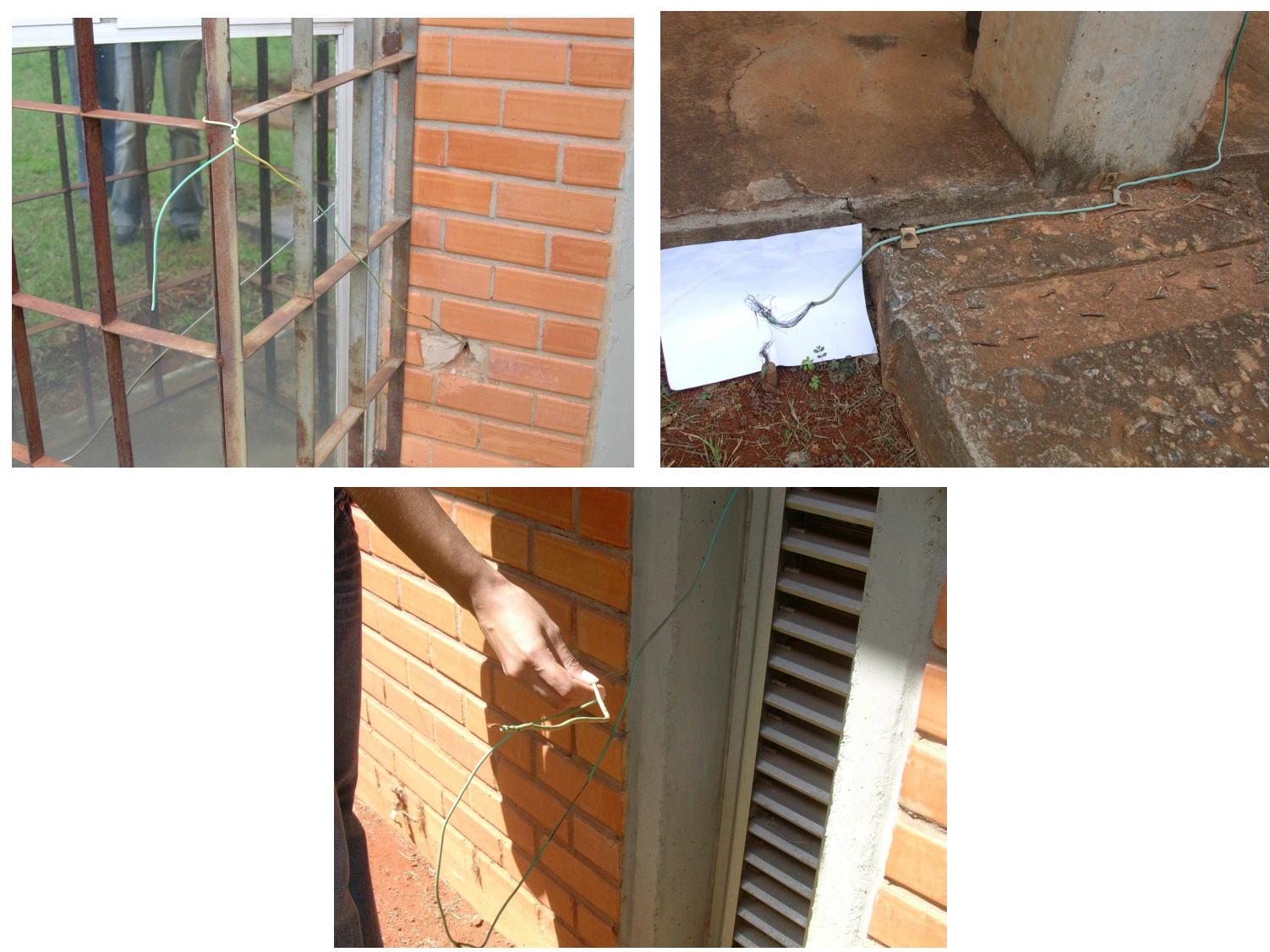

Foto 4.15 - "Terras Virtuais" Desconectados

FONTE: Pesquisa de Campo

Não há um anel de aterramento circundando toda a edificação. Há, entretanto, malhas de aterramento individuais servindo para os diversos quadros existentes e para cargas pontuais. Trata-se de malhas implementadas sem um projeto, feitas conforme a requisição dos instaladores dos quadros e equipamentos às quais elas servem. Essas malhas são isoladas entre si pela concepção de seus próprios instaladores, que não tiveram a preocupação em conhecer os outros eletrodos existentes na instalação, seja por optar em manter seu sistema isolado dos demais, ou por dificuldades de conhecimento da situação das instalações existentes até o momento. 


\subsubsection{Subestação}

Não fora confirmada a existência ou não de malha de aterramento para a Subestação. Não há um arquivo de um possível projeto, nem informações acerca deste assunto foram transmitidas pela manutenção técnica.

\subsubsection{Departamento da Engenharia Elétrica}

Há duas malhas de aterramento lineares, individuais e conectadas entre si em um ponto, conforme indicado em planta-baixa no anexo B. A primeira, que serve ao quadro dos Servidores do departamento, é constituída de seis hastes de 2,40 metros de comprimento e foi interligada à malha antiga existente nas proximidades. A foto 4.16 mostra as caixas de inspeção desta malha de aterramento e, a foto 4.17 mostra o detalhe da caixa de inspeção em que ocorre a conexão entre esta primeira malha e a malha antiga existente.

No entanto, a distância entre algumas hastes desta malha é inferior ao comprimento efetivo destes eletrodos, resultando eletricamente em uma quantidade inferior de hastes, por conta da ocorrência de zona de interferência. 


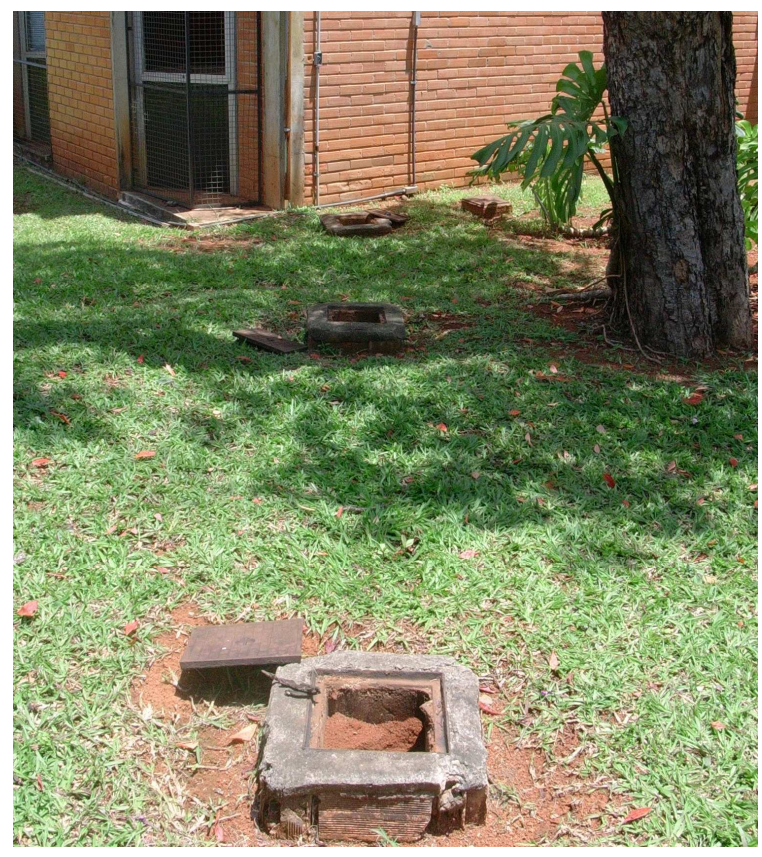

Foto 4.16 - Caixas de Inspeção da Malha de Aterramento FONTE: Pesquisa de Campo

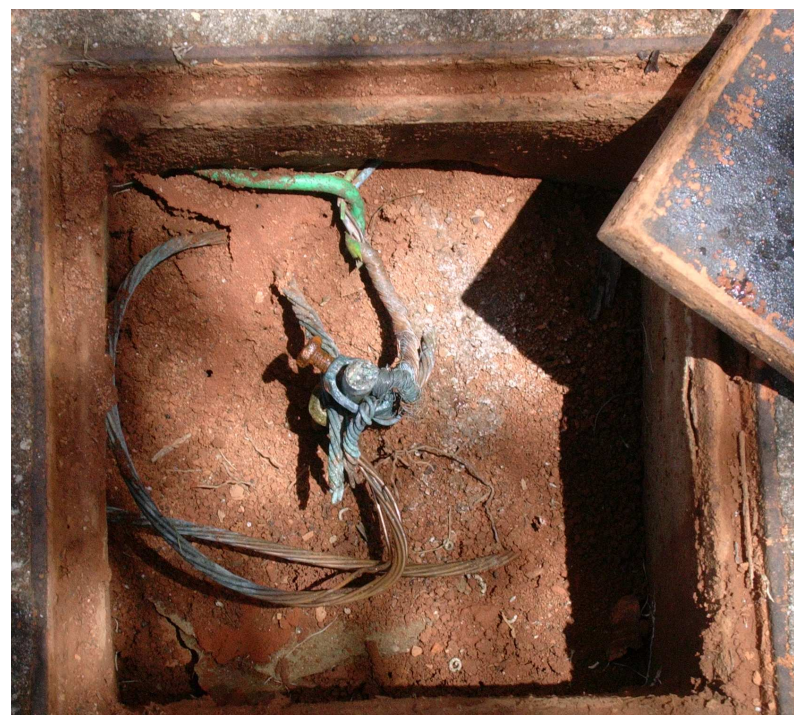

Foto 4.17 - Conexão entre as Malhas

FONTE: Pesquisa de Campo

A segunda malha serve ao quadro de distribuição do departamento.

Esta malha possui uma caixa de inspeção em cujas proximidades há um cano hidráulico com a finalidade de jorrar água em seu interior, conforme fotos 4.18 e 4.19. Essa situação demonstra uma tentativa de reduzir a resistividade da malha de aterramento neste trecho. 


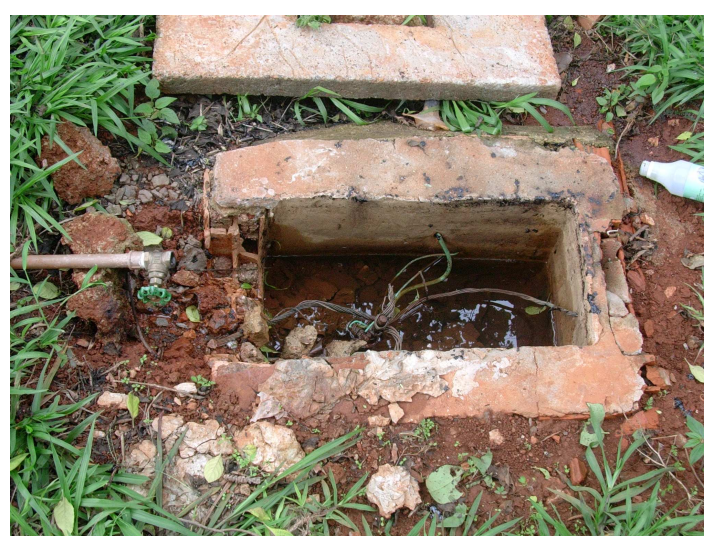

Foto 4.18 - Caixa de Inspeção FONTE: Pesquisa de Campo

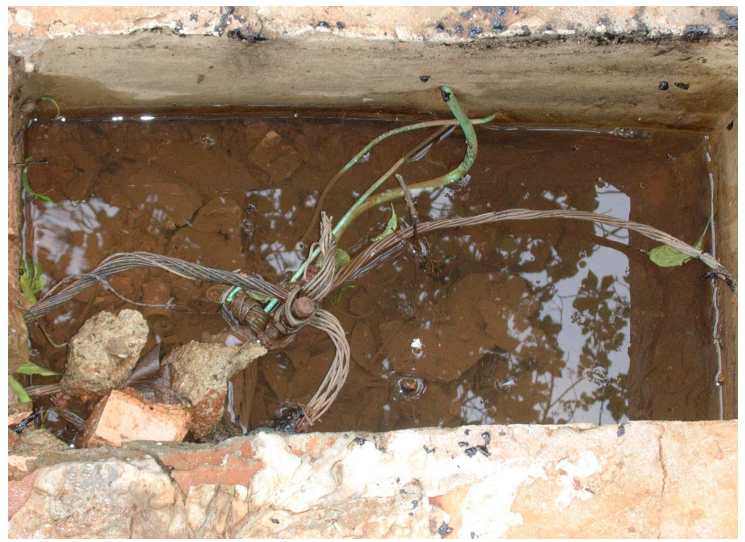

Foto 4.19 - Detalhe da Caixa de Inspeção FONTE: Pesquisa de Campo

O solo de Brasília é caracteristicamente seco, no entanto, o solo internamente à edificação da FT está sempre, em sua boa parcela, úmido, pois há sistema de irrigação. Uma maior quantidade de água dissolve melhor os sais existentes no solo fornecendo um meio eletrolítico favorável à circulação de corrente iônica.

\subsubsection{Departamento da Engenharia Mecânica}

Há quatro malhas lineares isoladas servindo às cargas do laboratório GRACO. Este ambiente possui um único quadro geral de alimentação, no entanto, há uma malha aterramento para este quadro e outras para cargas por ele alimentadas. As três malhas restantes servem equipamentos sofisticados, que segundo informações cedidas pela manutenção técnica, necessitam por exigência dos fabricantes, de malha de aterramento individual e isolada e com um determinado valor de resistência elétrica. São eles os equipamentos: torno mecânico, máquina hidráulica e oxicorte. Segundo informações obtidas, estes equipamentos são alimentados com fase, neutro e terra vindos de quadros terminais advindos do Quadro de Distribuição do Graco, e têm sua carcaça conectada às suas respectivas malhas de terra individuais. 
É importante lembrar que as normas prescrevem que o condutor de proteção de um dado circuito deve ter traçado paralelo e estar tão próximo quanto possível, eventualmente envolvendo os condutores de fase e neutro dos circuitos que estão protegendo. Essa prescrição visa o acoplamento magnético entre os condutores ativos e o de proteção. Além disso, massas protegidas por um mesmo dispositivo devem ser interconectadas a um mesmo eletrodo de aterramento.

$\mathrm{O}$ aterramento da carcaça e o aterramento pelo fio terra em pontos distintos gera loop de terra, causado pela diferença de potencial elétrico entre estes dois aterramentos, podendo causar fuga de corrente pela carcaça.

O efeito da zona de interferência foi também observado nestas malhas de aterramentos, entre eletrodos de uma mesma malha, como também entre duas das malhas de aterramento isoladas, as quais se encontram muito próximas entre si. Da mesma forma que ocorre nas malhas de aterramento do Departamento da Engenharia Elétrica, há desperdício de eletrodos.

\subsubsection{Demais departamentos}

Não foram identificadas quaisquer malhas de aterramento referentes aos outros quadros de distribuição advindos do QGBT, supondo-se que os condutores de proteção venham diretamente do barramento terra do QGBT.

Os quadros de distribuição cuja alimentação advém do transformador de 75 kVA, de acordo com informações cedidas pela manutenção técnica, não possuem malha de aterramento. Os cabos de terra destes quadros se utilizam erroneamente do aterramento da carcaça e do páraraios de linha deste transformador, que é composto por uma única haste. 


\section{Capítulo 5}

\section{A Eqüipotencialização na Faculdade de Tecnologia}

Neste capítulo serão apresentados comentários acerca dos dados obtidos em campo, e que foram discorridos no capítulo 4, tendo como base a teoria apresentada nos tópicos anteriores deste trabalho.

\subsection{Aterramentos individuais}

A situação descrita no item 4.3 deste relatório vai contra os princípios de eqüipotencialização, permitindo que haja diferença de potencial entre a corrente que circula as diversas malhas, gerando-se as correntes de sobretensão. Trata-se de descargas laterais, resultado da resistência finita dos condutores à passagem de corrente elétrica e da indução magnética. A presença dessas malhas de aterramento isoladas entre si, na mesma área de influência permitirá elevação de potencial do solo quando da ocorrência de descargas atmosféricas ou de curtocircuitos fase-terra. Tal fenômeno representa riscos à segurança pessoal e aos equipamentos.

O prédio da FT é composto por vários blocos que formam uma edificação única.Embora haja três entradas de alimentação individuais neste prédio, os aterramentos existentes para as diferentes partes das instalações devem ser unificados, pois estão na mesma área de influência. 


\subsection{Compatibilidade eletromagnética}

A incompatibilidade eletromagnética, no que se refere aos problemas associados diretamente às instalações elétricas de uma dada edificação, está relacionada a perturbações geradas por falhas na sua execução, permitindo que eventos a que o sistema está sujeito, tais como curto-circuitos, queda de raios, manobras, surtos, afetem diretamente o funcionamento dos equipamentos. São de perturbações conduzidas, que se acoplam aos circuitos.

Neste contexto, um aterramento mal implementado, ignorando-se a aplicação do conceito de eqüipotencialização, representa uma fonte de perturbações, devido à distribuição de correntes, dos campos eletromagnéticos e tensões induzidas quando da ocorrência dos fenômenos acima citados. Essas perturbações se acoplam ao aterramento pelo mecanismo de acoplamento por impedância comum.

Um aterramento adequado é imprescindível pois atuará como um componente essencial para minimização dos efeitos de interferência no sistema.

A existência de aterramentos isolados para cargas alimentadas pelo mesmo quadro incorre em circulação de corrente por trajeto indevido, onde um dos trechos é representado pela terra que interliga os dos aterramentos, determinando-se os chamados loops de corrente. Este fenômeno origina flutuações de tensão, tornando instável a referência de terra.

O conceito de aterramento, no que concerne a EMC não se refere a um baixo valor de resistência de terra, pois tal condição não é fundamental à manutenção da compatibilidade eletromagnética. Sob esta ótica, o sistema de aterramento, que deve ser visto como um circuito para favorecer o fluxo de corrente sob a menor indutância possível. 


\subsection{Barramento equipotencial principal}

Um barramento equipotencial principal nas instalações se faz necessário por questões de organização e funcionalidade. No QGBT da FT, a ausência de um barramento terra individual fere o quesito funcionalidade e proteção, posto que determina uma situação fora dos padrões adotados pela concessionária local; além de não permitir determinação de circuitos de saída no esquema TN-S, segundo prescrição da NBR 5410. Conforme dados da tabela 4.1, nem todos os quadros de distribuição possuem barramentos de terra e neutro separados.

Além disso, esse barramento para função de terra terá função de BEP dentro da instalação, permitindo facilidades de conexão de quaisquer interligações para fins de eqüipotencialização, pois esta estrutura será bastante acessível. Tal situação determina uma condição mais criteriosa no que se refere às prescrições da norma.

Dentro da instalação em questão, o aumento da eficiência de proteção soma à proteção das pessoas contra choques elétricos, a diminuição de possibilidade de queima dos equipamentos, que são em parte sensíveis e/ou caros, além de se constituírem em patrimônio da Universidade.

\subsection{Barramentos equipotenciais locais}

Barramentos equipotenciais locais também são recomendados por questão de proteção contra choques elétricos e de compatibilidade eletromagnética, para se vincular indiretamente todas as massas da instalação à eqüipotencialização principal.

Em função das dimensões da edificação, que determina a presença de malhas de terra e quadros de distribuição muito distantes um dos outros, estes barramentos locais determinarão cumprimentos menores aos condutores de eqüipotencialização, a fim de se evitar quedas de 
tensão inaceitáveis, especialmente para altas freqüências. A localização de BELs proporciona ligação mais eficaz também do ponto de vista de atenuação das interferências eletromagnéticas.

A estes barramentos locais, portanto, serão interligadas as estruturas mais próximas que devem fazer parte da eqüipotencialização da instalação. 


\section{Capítulo 6}

\section{Recomendações}

Existe a necessidade de instalação de uma barra de cobre dentro da Subestação nas proximidades do QGBT com a função de barramento de terra. Os cabos de terra que seguem para os circuitos de alimentação devem ser migradas para esta estrutura. Esta nova barra deverá ser jumpeada com a barra já existente no QGBT e terá, a partir de então, função unicamente de barramento de neutro. Com esta configuração final, o barramento de terra terá a função de BEP dentro desta instalação. Neste contexto, quaisquer conexões para fins de eqüipotencialização a serem feitas no QGBT devem ser implementadas neste novo barramento de terra.

Esta estrutura deverá ser acomodada em um quadro, em localização definida em planta.

Em todos os quadros de distribuição e no QGBT devem ser instalados protetores contra surtos (DPS), adequadamente especificados, a fim de evitar que surtos provenientes de quaisquer partes da instalação afetem as cargas, principalmente as mais sensíveis. Para isso, naqueles quadros onde há somente um barramento com ambas as funções de terra e neutro, deverá ser providenciada instalação de outro barramento com posterior separação dos condutores de terra e neutro. Importante lembrar que o barramento de neutro deve ser isolado da carcaça do quadro, ao passo que o barramento de terra deve ser jumpeado a ela. 
Os cabos de terra correspondentes aos "terras virtuais" dos equipamentos, que estão diretamente conectados ao solo, devem ser conduzidos para os barramentos terra de seus respectivos quadros. Deve ser provido condutor terra a pelo menos todos os circuitos de tomada, sejam eles já existentes ou a serem instalados. Esta é a única forma do aterramento fornecido às instalações prover segurança e proteção às pessoas e aos equipamentos.

A fim de se evitar elevação do potencial do solo, mesmo aquelas malhas referentes ao aterramento de partes da instalação que não são alimentadas pelo QGBT deverão ser interconectadas entre si, pois estão geograficamente internas ao campo de influência. Como se trata de uma área de proporções consideráveis é aconselhável a instalação de BELs para fazer interconexões intermediárias, evitando-se condutores de eqüipotencialização muito longos.

Quando da implementação do anel subterrâneo circundando toda a edificação esses aterramentos individuais já existentes se tornarão aterramentos suplementares, que quando interconectados entre si e ao BEP garantirão eqüipotencialização às instalações. Aterramentos isolados dentro da edificação, que representam uma única área de influência, não são recomendados por permitir geração de potenciais perigosos às pessoas quando da circulação de correntes de descarga ou de falta. Para solução deste problema devem ser feitas quantas equipotencializações locais forem necessárias. 


\section{Capítulo 7}

\section{Considerações Finais}

Entre as dificuldades relacionadas ao desenvolvimento do projeto citam-se as precárias documentações referentes às instalações originais do prédio e à inexistência de documentações referentes às modificações feitas ao longo dos anos. Essas alterações nas instalações elétricas sempre tiveram caráter individual, sem preocupação na comunicação e/ou transmissão de informações entre os executores e os departamentos técnicos responsáveis pela manutenção, inclusive da Prefeitura. Os projetos executados não possuem "as-built" e na sua maioria são de conhecimento somente do executor. Esse tipo de comportamento não garante eficiência e segurança das instalações, pois não há uma responsabilidade associada aos projetos executados.

Segundo informações obtidas, algumas instalações foram realizadas por empresas privadas contratadas, sem um conhecimento e controle interno dos responsáveis técnicos da Prefeitura.

Como não há registro das alterações até então implementadas, existe a dificuldade em manutenções e alterações conseguintes. Neste contexto, justifica-se completamente a existência de erros de concepção nas instalações, pois não se conhece, e nem há preocupação em se 
descobrir, a situação atual do prédio, bem como as estruturas instaladas e as necessidades de cada departamento. As instalações da FT são tratadas como blocos individuais e independentes eletricamente entre si.

As informações contidas neste trabalho foram resultado de muita interação com os diversos técnicos da FT, SG-11 e Prefeitura, bem como de inspeções e vistorias, pois havia diversas informações conflitantes e de conhecimento restrito a algumas pessoas.

O aterramento, um dos importantes componentes considerados numa filosofia mais abrangente de proteção, deve atender a uma ampla variedade de funções dentro de um sistema. Essas funções são constituídas de aterramento para o sistema de alimentação (Subestação), aterramento de sistemas de proteção contra descargas atmosféricas, aterramento de alta frequiência, de aterramento para descargas eletrostáticas, condutor de terra de segurança, condutor de terra e terra de referência.

Dessa forma, apesar dessa união ser tecnicamente recomendada, a complexidade associada e a dificuldade de análise do comportamento do sistema, não é possível ao aterramento desempenhar perfeitamente todas estas funções. Algumas dessas funções são inclusive conflitantes. Para o desempenho dessas funções, na perspectiva de aplicação à engenharia, foi concebida a filosofia de aterramento com eqüipotencialização.

As práticas de eqüipotencialização podem ser muito eficientes, mesmo em condições de valor elevado de impedância de aterramento, se sua aplicação é baseada numa concepção de proteção consistente, pois o conceito importante na prática é a diferença de potencial à qual as pessoas e equipamentos ficam submetidos em situação de falha no sistema elétrico.

Essa pesquisa serviu como um dos primeiros esforços para fomentar a introdução do conceito de eqüipotencialização na FT, com a intenção de que o conhecimento seja assimilado e um projeto seja implementado com bases nesta filosofia. 


\section{Referências Bibliográficas}

[1]“ABNT NBR 14136 - Plugues e tomadas para uso domestico e análogo até 20 A, 250 V c.a. - Padronização" Associação Brasileira de normas Técnicas, 2002;

[2] “ABNT NBR 5410/2004 - Instalações Elétricas de Baixa Tensão “ Associação Brasileira de normas Técnicas ,2004;

[3] “ABNT NBR 5419/2005 - Proteção de estruturas contra descargas atmosféricas" Associação Brasileira de normas Técnicas, 2005;

[4] COTRIM, Ademaro A.M.B. Instalações Elétricas. São Paulo: Editora Prentice Hall, $4^{\mathrm{a}}$ edição, 2003;

[5] COUTINHO, F. N. \& ALTOÉ, C. A. Levantamento de Estruturas que Necessitam de SPDA na UnB e Análise de Seus Efetivos Sistemas de Proteção. Monografia de Graduação, 2003;

[6] CREDER, H. Instalações Elétricas. São Paulo: Prentice Hall, $4^{\mathrm{a}}$ edição, 2003;

[7] FILHO, Silvério V. - Aterramentos elétricos. São Paulo: Artliber Editora, 2005;

[8] GRAY, Alexander - Principles and practice of electritical Engineering, $5^{\circ}$ edição, McGraw Book Company, 1940;

[9] IEC - International Electrotechnical Comission, IEC 1024-1-1 1993; Protection of structures against lighting - Part 1: General principles - section 1; Guide A-Selection of protection levels of lighting protection systems;

[10] IEC - International Electrotechnical Comission, IEC 60554-1 (CEI 28-6): Insulation coordination for equipment within low voltage systems. Part 1: Principles, requirements and tests. 1994; 
[11] IEC - International Electrotechnical Comission, IEC 61312-2 - TS 1999: Protection against Lightning Electromagnetic Impulse (LEMP). Part 2: Shielding of strutures, bonding inside strutures and earthing;

[12] IEC - International Electrotechnical Comission, IEC 61312-3 - TS 2000: Protection against Lightning Electromagnetic Impulse (LEMP). Part 3: Requirements of surge protective devices relating to LEMP;

[13] IEC - International Electrotechnical Comission, IEC 61643-1999: Surge Protective Devices Connected to Low Voltage Power Distribution Systems: Part 1: Performance requirements and testing methods; Part 2: Selection and Application Principles;

[14] IEC - International Electrotechnical Comission, IEC 64/1125/CDV: General basic information regarding surge overvoltages and surge prrotection in low voltage AC power systems. Abril/2000;

[15] JUNIOR, C. A. F. M. \& SILVA, N. S. A. Minimização de Riscos de Choque Elétrico e Danos a Equipamentos por Meio de Aterramento Adequado. Monografia de Graduação, 2004;

[16] KINDERMANN, Geraldo \& CAMPAGNOLO. Aterramento Elétrico. Porto Alegre: Sagra - D.C. Luzzatto, 1995;

[17] MAMEDE, João F. Instalações Elétricas Industriais. Rio de Janeiro : Editora LTC Livros Técnicos e Científicos S.A, 6 edição, 2002;

[18] NISKIER, Julio A.J.M. Instalações Elétricas. Rio de Janeiro: Editora LTC, 4a edição, 2000 ;

[19] OLIVEIRA, Dennys R. (2003). Análise da Interação Solo-Atmosfera durante a Secagem para a Argila Porosa de Brasília. Dissertação de Mestrado, Publicação G.DM-110/-3, Departamento de Engenharia Civil e Ambiental, Universidade de Brasília, DF, 168 p;LL 
[20] OLIVEIRA, Luiz César B. Material de curso sobre Projeto de Aterramento Elétrico. Brasília, 2004;

[21] Protection of Strutures Against Lightning, part 1, General Principles, ENV 61024-1, 1995;

[22] Revista Eletricidade Moderna - Ensaio de Proteção contra Descargas Atmosféricas em Edifícios de Alvenaria Estrutural, A. P.Reis Miranda, n 354, setembro de 2003;

[23] Revista Eletricidade Moderna - Como Obter um Aterramento Adequado para Proteção contra Raios?, Alain Rousseau, da APS-Assistance Protection System (França), ${ }^{\circ}$ 358, janeiro de 2004;

[24] Revista Eletricidade Moderna - Retorno para a Fonte de Correntes de Falta à Terra, A.P.Reis Miranda, engenheiro consultor, $n^{\circ} 359$, fevereiro de 2004;

[25] Revista Eletricidade Moderna - $\mathrm{n}^{\circ} 368$ - O que Muda com a Nova Edição da Norma NBR-5419, $\mathrm{n}^{\circ}$ 368, novembro de 2004;

[26] Revista Eletricidade Moderna - Proteção contra Choques Elétricos: O que Muda com a Nova Edição da NBR 5410, redação da revista EM, n 369, dezembro de 2004;

[27] Revista Eletricidade Moderna - Proteção contra Surtos de Tensão Sofre Modificações na Nova Edição da NBR 5410 - Jobson Modena, n 372, março de 2005;

[28] Revista Eletricidade Moderna - Emendas em Ferragens para Proteção contra Descargas Atmosféricas; Hélio Sueta e Geraldo Francisco Burani do Instituto de Eletrotécnica e Energia da USP (IEE/SP), n³73, abril de 2005;

[29] Revista Eletricidade Moderna -Tomadas e Plugues: o Padrão Brasileiro ABNT NBR 14136, n 389 , agosto de 2006;

[30] SANT'ANA, C. J. Estudo do Desempenho de Sistemas de Aterramento Frente às Descargas Atmosféricas em Instalações de Baixa e Média Tensão. 2005. 111 f. Dissertação 
(Mestrado em Engenharia Mecânica) - Faculdade de Engenharia, Universidade Estadual Paulista, Bauru, 2005;

[31] http://www.fisica-potierj.pro.br/Sobre_Raios_\%20e_Outros/Aterramento.pdf, acessado em 3 de setembro de 2006;

\section{[32] Universidade Rural do Rio de Janeiro,}

http://www.ufrrj.br/institutos/it/de/acidentes/eletric.htm, acessado em 3 de setembro de 2006;

\section{[33] Fundacentro,}

http://www.fundacentro.gov.br/ARQUIVOS/PUBLICACAO//SST_industria_da_construcao.pdf , acessado em 3 de setembro de 2006;

[34] https://www.informatica.org.br/portal/html/b2b/tecnica/f1conda.pdf, acessado em 10 de setembro de 2006;

[35] Electric Ground, http://www.eletricground.com.br, acessado em 16 de setembro de 2006;

[36] Instituto Nacional de Pesquisas Espaciais, http://www.inpe.br/, acessado em 29 de outubro de 2006;

[37] Mi Omega Engenharia Elétrica, http://www.miomega.com.br/miomega.htm, acessado em 05 de novembro de 2006;

\section{[38] Mi Omega Engenharia Elétrica,}

http://www.miomega.com.br/nbr5410/html/nova\%20norma/definicoes.htm, acessado em 05 de novembro de 2006;

[39] http://professores.unisanta.br/valneo/links.htm, acessado em 08 de novembro de 2006;

[40] http://www.fazfacil.com.br/EletricidadeGlossario3.htm, acessado em 10 de novembro de 2006;

[41] Ideal Engenharia, http://www.idealengenharia.com.br/calculo/artigotc.htm, acessado em 10 de novembro de 2006; 
[42] http://www.del.ufms.br/Materiais.pdf, acessado em 10 de novembro de 2006;

[43] http://www.raios.com.br, acessado em 10 de novembro de 2006;

[44] https://www.planalto.gov.br/ccivil/_Ato2004-2006/2006/Lei/L11337.htm, acessado em 18 de novembro de 2006;

[45] Guia Trabalhista, http://www.guiatrabalhista.com.br/legislacao/nr/nr10.htm, acessado em 18 de novembro de 2006;

[46] Universidade Federal de Sao Joao del- Rei - UFSJ, http://www.eletrica.ufsj.edu.br/pub/eletrotecnica/norma5410/09_compatibilidade.pdf, acessado em 18 de novembro de 2006;

\section{[47] Companhia Paranaense de Energia - COPEL,} http://www.copel.com/sitearquivos.nsf/arquivos/equipontecializacao_em_instalacoes_prediais/\$ FILE/equip.pdf, acessado em 18 de novembro de 2006;

\section{[48] Revista Ferroviária Online,}

http://www.revistaferroviaria.com.br/Alstom2004/trabalhos/avaliacao_protecao_descargas.htm, acessado em 18 de novembro de 2006;

[49] http://paginas.terra.com.br/servicos/AdvancedRF/at4.htm, acessado em 23 de novembro de 2006;

[50] http://www.fortunecity.com/victorian/belvedere/112/terra.htm, acessado em 23 de novembro de 2006;

[51] Home Page de Idelton Lemos, http://br.geocities.com/idelton/Aterramento.pdf, acessado em 26 de novembro de 2006;

[52] http://m.albernaz.sites.uol.com.br/aterramento.htm, acessado em 26 de novembro de 2006;

[53] http://www.procobre.org/pr/pdf/pdf_pr/03_aterrame.pdf, acessado em 26 de novembro de 2006; 
[54]“ABNT NBR IEC 50 - Vocabulário Eletrotécnico Internacional - Capítulo 826:

Instalações Elétricas em Edificações” Associação Brasileira de normas Técnicas, 1997;

[55] http://www.ceb.com.br/CebNovo/Ceb/Ceb/area.cfm?id_area=13\&nivel=2, acessado em 29 de novembro de 2006;

[56] http://www.biblioteca.unesp.br/bibliotecadigital/document/?did=3350, acessado em 29 de novembro de 2006;

[57] IEC - International Electrotechnical Comission, IEC 479-1: "Effects of Current Passing Through the Human Body"; 


\begin{abstract}
ANEXO A
A tabela 1 especifica alguns tipos de eletrodos, bem como seus materiais:
\end{abstract}

Tabela 1 - Tipos de Eletrodos

FONTE: Cotrim modificado por Idelton Lemos

\begin{tabular}{|c|c|c|}
\hline Tipo de Eletrodo & Dimensões mínimas & Observações \\
\hline Tubo de aço zincado & $\begin{array}{c}2,40 \mathrm{~m} \text { de comprimento e diâmetro } \\
\text { nominal de } 25 \mathrm{~mm}\end{array}$ & Enterramento totalmente vertical \\
\hline Perfil de aço zincado & $\begin{array}{l}\text { Cantoneira de }(20 \mathrm{~mm} \times 20 \mathrm{~mm} \times 3 \mathrm{~mm}) \\
\text { com } 2,40 \mathrm{~m} \text { de comprimento }\end{array}$ & Enterramento totalmente vertical \\
\hline Haste de aço zincado & $\begin{array}{l}\text { Diâmetro de } 15 \mathrm{~mm} \text { com 2,00 ou 2,40 m } \\
\text { de comprimento }\end{array}$ & Enterramento totalmente vertical \\
\hline $\begin{array}{c}\text { Haste de aço revestida de } \\
\text { cobre }\end{array}$ & $\begin{array}{c}\text { Diâmetro de } 15 \mathrm{~mm} \text { com } 2,00 \text { ou } 2,40 \mathrm{~m} \\
\text { de comprimento }\end{array}$ & Enterramento totalmente vertical \\
\hline Haste de cobre & $\begin{array}{l}\text { Diâmetro de } 15 \mathrm{~mm} \text { com 2,00 ou 2,40 m } \\
\text { de comprimento }\end{array}$ & Enterramento totalmente vertical \\
\hline Fita de cobre & $\begin{array}{c}50 \mathrm{~mm} 2 \text { de seção, } 2 \mathrm{~mm} \text { de espessura e } \\
10 \mathrm{~m} \text { de comprimento }\end{array}$ & $\begin{array}{l}\text { Profundidade mínima de } 0,60 \mathrm{~m} \text {. } \\
\text { Largura na posição vertical }\end{array}$ \\
\hline Fita de aço galvanizado & $\begin{array}{c}100 \mathrm{~mm} 2 \text { de seção, } 3 \mathrm{~mm} \text { de espessura e } \\
10 \mathrm{~m} \text { de comprimento }\end{array}$ & $\begin{array}{l}\text { Profundidade mínima de } 0,60 \mathrm{~m} \text {. } \\
\text { Largura na posição vertical }\end{array}$ \\
\hline Cabo de cobre & $\begin{array}{l}50 \mathrm{~mm} 2 \text { de seção e } 10 \mathrm{~m} \text { de } \\
\text { comprimento }\end{array}$ & $\begin{array}{c}\text { Profundidade mínima de } 0,60 \mathrm{~m} \text {. } \\
\text { Posição horizontal }\end{array}$ \\
\hline Cabo de aço zincado & $\begin{array}{l}95 \mathrm{~mm} 2 \text { de seção e } 10 \mathrm{~m} \text { de } \\
\text { comprimento }\end{array}$ & $\begin{array}{c}\text { Profundidade mínima de } 0,60 \mathrm{~m} \text {. } \\
\text { Posição horizontal }\end{array}$ \\
\hline Cabo de aço cobreado & $\begin{array}{l}50 \mathrm{~mm} 2 \text { de seção e } 10 \mathrm{~m} \text { de } \\
\text { comprimento }\end{array}$ & $\begin{array}{c}\text { Profundidade mínima de } 0,60 \mathrm{~m} . \\
\text { Posição horizontal }\end{array}$ \\
\hline
\end{tabular}




\section{ANEXO B}

Planta baixa da edificação ilustrando as malhas de aterramento existentes e a localização dos quadros de distribuição da Faculdade de Tecnologia. 